\title{
An Assessment of Technologies to Provide Extended Sludge Retrieval from Underground Storage Tanks at the Hanford Site
}

J. A. Bamberger

July 2000

Prepared for the U.S. Department of Energy

under Contract DE-AC06-76RLO 1830

Pacific Northwest National Laboratory

Richland, Washington 99352 



\section{DISCLAIMER}

This report was prepared as an account of work sponsored by an agency of the United States Government. Neither the United States Government nor any agency thereof, nor any of their employees, make any warranty, express or implied, or assumes any legal liability or responsibility for the accuracy, completeness, or usefulness of any information, apparatus, product, or process disclosed, or represents that its use would not infringe privately owned rights. Reference herein to any specific commercial product, process, or service by trade name, trademark, manufacturer, or otherwise does not necessarily constitute or imply its endorsement, recommendation, or favoring by the United States Government or any agency thereof: The views and opinions of authors expressed herein do not necessarily state or reflect those of the United States Government or any agency thereof. 


\section{DISCLAIMER}

\section{Portions of this document may be illegible in electronic image products. Images are produced from the best available original document.}




\section{Acknowledgments}

The extended sludge retrieval activities are part of the Retrieval Process Development and Enhancements (RPD\&E) Project under direction of the US Department of Energy Office of Science and Technology Tanks Focus Area. The purpose of the Retrieval Process Development and Enhancements Project is to understand retrieval processes including ongoing and existing technologies, gather data on these technologies, and relate the data to specific tank problems such that end users have requisite technical bases to make retrieval and closure decisions. This work was conducted in conjunction with Eric Pacquet and John Garfield, Numatec Hanford Company, and Craig Shaw, Cogema Engineering Corp. 



\section{Summary}

The purpose of this study was to identify sludge mobilization technologies that can be readily installed in double-shell tanks along with mixer pumps to augment mixer pump operation when mixer pumps do not adequately mobilize waste. The supplementary technologies will mobilize sludge that may accumulate in tank locations out-of-reach of the mixer-pump jet and move the sludge into the mixerpump range of operation. The identified technologies will be evaluated to determine if their performances and configurations are adequate to meet requirements developed for enhanced sludge removal systems.

The study proceeded in three parallel paths to identify technologies that: 1) have been previously deployed or demonstrated in radioactive waste tanks, 2) have been specifically evaluated for their ability to mobilize or dislodge waste simulants with physical and rheological properties similar to those anticipated during waste retrieval, and 3) have been used in similar industrial conditions, but not specifically evaluated for radioactive waste retrieval.

\section{Technologies Evaluated}

Technologies were identified that have already been deployed or are being developed for deployment to remediate radioactive waste tanks. These technologies include:

- Pulsed Air

- Pulsating Mixer Pump

- Fluidic Pulse-Jet Mixing

- C-106 Sluicer

- Borehole-Miner Extendible-Nozzle

- Waste-Retrieval End Effector

- High-Pressure Scarifier

- Flygt Mixer.

All of the technologies, with exception of the Flygt mechanical mixer, are based on jet mixing. The jet fluid is air, slurry, or water. The jet pressure, duration, and pulse rate vary based on the technology. Several of the technologies are very similar. The pulsating mixer pump and fluidic pulse-jet mixing both create jets by using suction to draw slurry from the tank into a tube and pressure to expel the fluid jet back into the tank. The C-106 sluicer and the borehole-miner extendible-nozzle are both based on sluicing; however, the borehole miner operates at a higher pressure [20.7 MPa (3000 psi)] than the C-106 sluicer [2.07 $\mathrm{MPa}(300 \mathrm{psi})]$ and has an increased jet range based on the extension of the nozzle away from the mast using its extendible arm. The waste-retrieval end effector and the high-pressure scarifier are both based on scarification - using a high-pressure, low-flow-rate jet to fracture and erode solids, with the high-pressure scarifier operating at significantly higher pressure $[379 \mathrm{MPa}(55,000 \mathrm{psi})]$ than the wasteretrieval end effector [68.9 or $207 \mathrm{MPa}(10,000$ or $30,000 \mathrm{psi})]$.

The performance of additional technologies have been evaluated for their ability to mobilize or dislodge a specific type of simulated waste such as sludge, hard pan, or salt cake. Other technologies have been identified as promising based on industrial application in other tank-cleaning environments. 


\section{Criteria for Evaluation}

To compare the technologies, their physical and operating characteristics have been summarized. Items addressed include the operating principal, ability to dislodge waste forms, and other operating characteristics. The technologies are ordered by jet pressure from low to high. Then the technologies are rated with respect to meeting criteria developed for enhanced sludge removal performance. Performance is grouped into three categories: the technology either meets the criteria, has the ability to be modified to meet the criteria, or is not able to be readily modified to meet the criteria.

Specific criteria include

- The device shall assist waste mobilization in dead areas.

- The device shall enhance mobilization for a radius of $3.0 \mathrm{~m}(10 \mathrm{ft})$ in waste with a shear strength of $1.96 \mathrm{kPa}\left(41 \mathrm{lbf} / \mathrm{ft}^{2}\right)$.

To put the shear strength value $\left[1.96 \mathrm{kPa}\left(41 \mathrm{lbf} / \mathrm{ft}^{2}\right)\right]$ in perspective, it is compared with simulants developed at Pacific Northwest National Laboratory to model waste properties (Powell et al. 1997, Bamberger et al. 1998). A 50\% kaolin, 13\% plaster, 37\% water simulant developed to model sludge had a shear strength of $2.5 \mathrm{kPa}\left(52 \mathrm{lbf} / \mathrm{ft}^{2}\right)$, just slightly higher than the target selected for extended sludge retrieval equipment. A $22.5 \%$ kaolin, $40 \%$ plaster, $37.5 \%$ water simulant developed to model hard pan had a shear strength of $150 \mathrm{kPa}\left(3133 \mathrm{lbf} / \mathrm{ft}^{2}\right)$. A salt cake simulant (84\% dynamate fertilizer in water) had a compressive strength of $19 \mathrm{MPa}(396,825$ $\left.\mathrm{lbf} / \mathrm{ft}^{2}\right)$. With respect to the types of simulants developed for evaluation of waste remediation equipment, the shear strength value of $1.96 \mathrm{kPa}\left(41 \mathrm{lbf} / \mathrm{ft}^{2}\right)$ selected as the basis for evaluation of extended sludge retrieval is very low.

- The device shall pass through a 12.7 - to $15.2-\mathrm{cm}$ (5- to 6-in.)-diameter riser. ${ }^{1}$

\section{Technology Summary}

Based on the evaluation criteria, one technology, the borehole-miner extendible-nozzle, has the proven ability to meet key primary requirements. The borehole-miner extendible-nozzle can mobilize

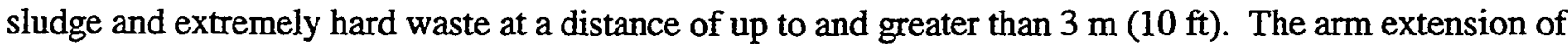
$3 \mathrm{~m}(10 \mathrm{ft})$, and its ability to move back and forth can be used to sweep waste from collection piles deposited by the mixer pump back into the mixer pump path or toward the retrieval pump inlet. The current borehole-miner extendible-nozzle mast is larger than the 15.2-cm- (6-in.-) diameter riser; however, this parameter could be readily modified for the application.

\footnotetext{
${ }^{1}$ Larger risers $[0.30,0.61$, and $1.1 \mathrm{~m}(12,24$, and $42 \mathrm{in.}$ in diameter $)]$ may be available for extended sludge retrieval system deployment in specific tanks; however, for this study the 15.2-cm (6-in.) riser was selected as the evaluation criteria because it represents the most prevalent riser size for system deployment.
} 
Two other technologies, the pulsating mixer pump and fluidic pulse-jet mixing will readily fit through a 15.2-cm (6-in.)-diameter riser; however, these technologies need to be evaluated to determine the effective cleaning radius of their jets and the range of shear strengths of sludge that the jets can dislodge. 


\section{Contents}

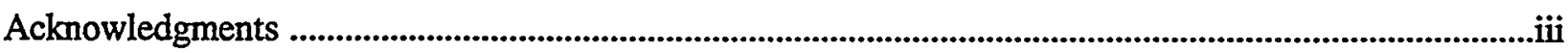

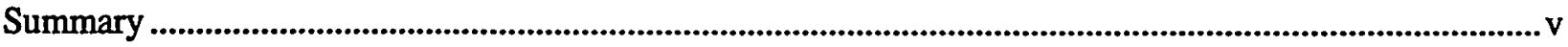

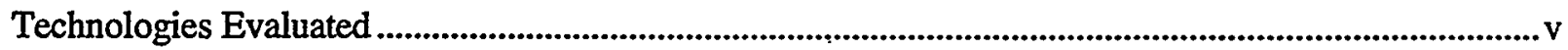

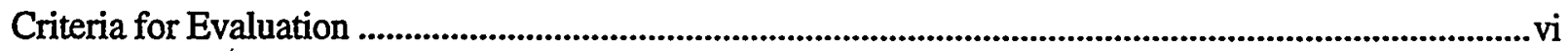

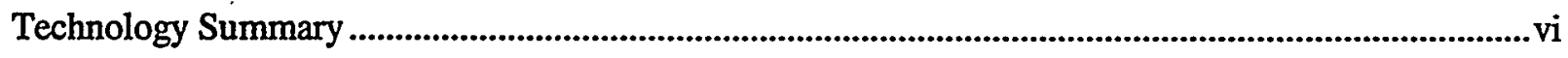

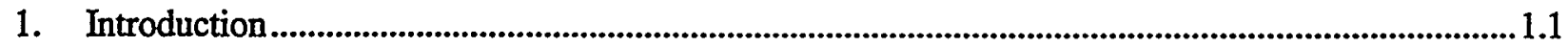

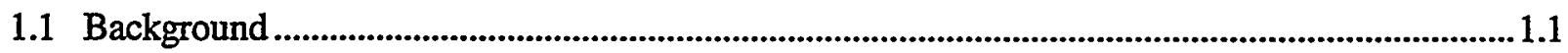

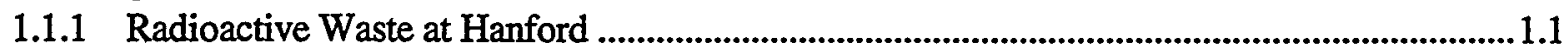

1.1.2 Waste Treatment and Immobilization Approach ............................................................ 1.2

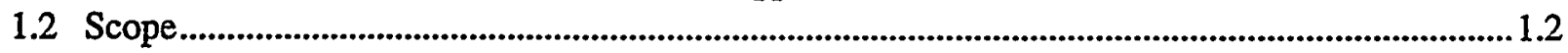

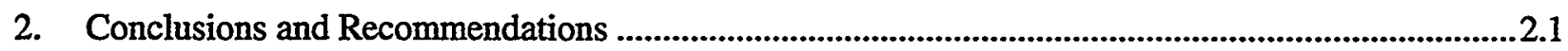

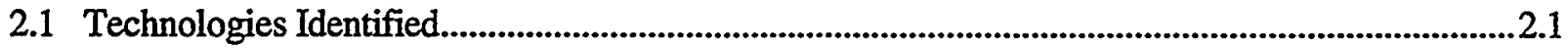

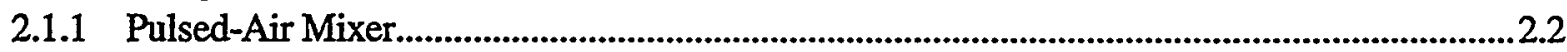

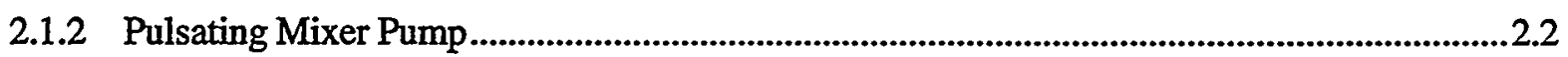

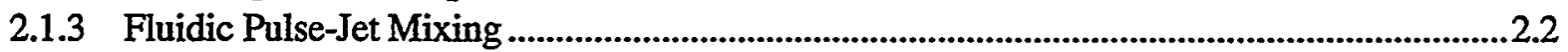

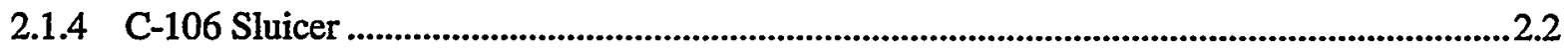

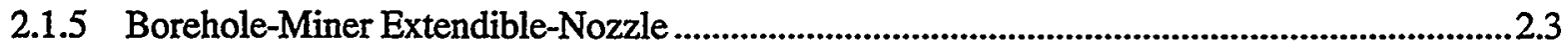

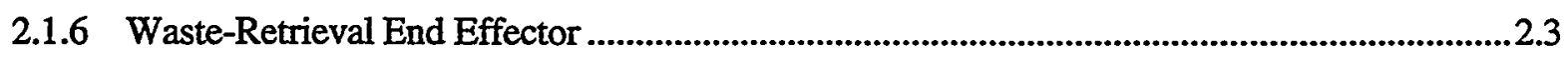

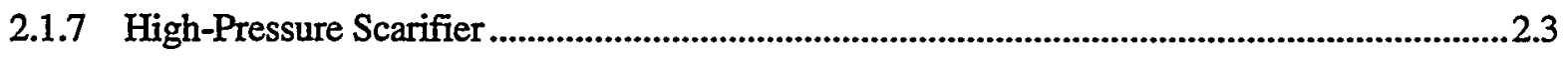

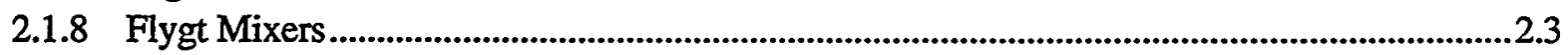

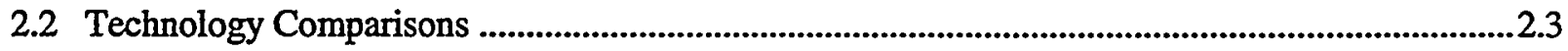

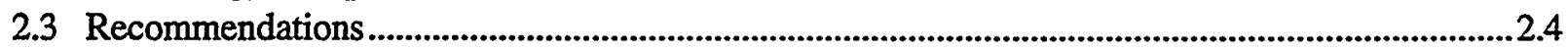

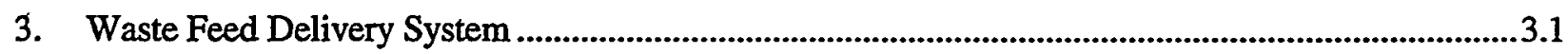

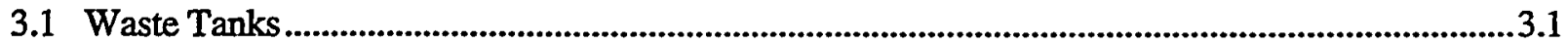

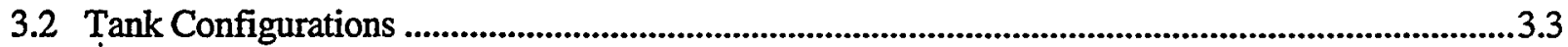

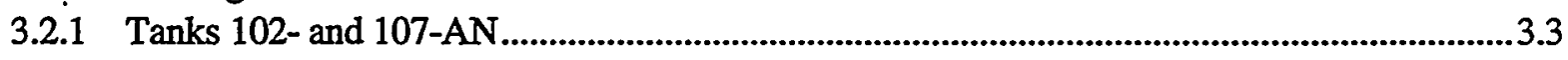

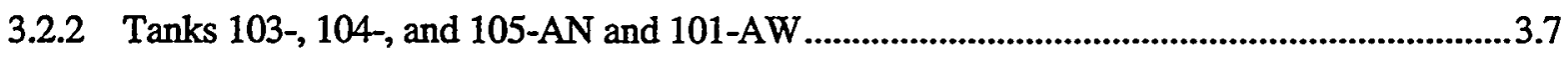

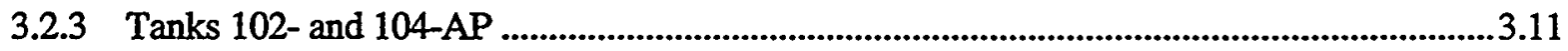

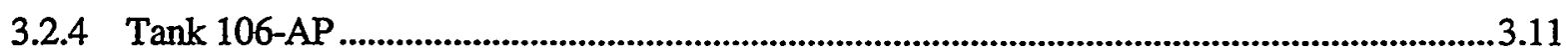

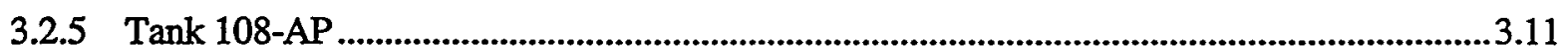

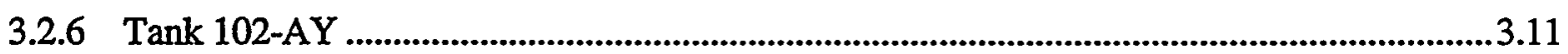

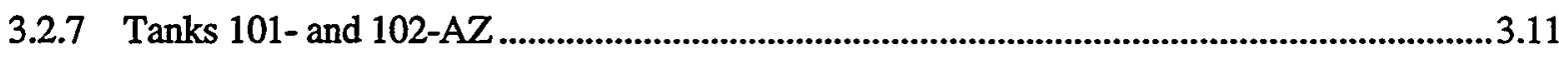

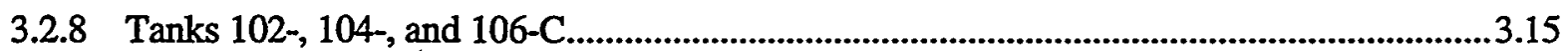

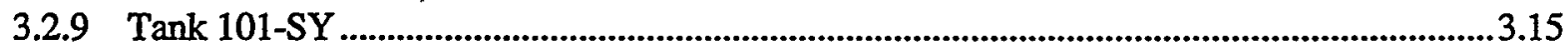

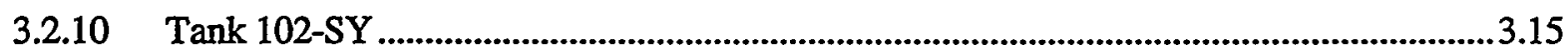

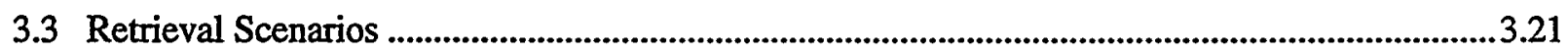

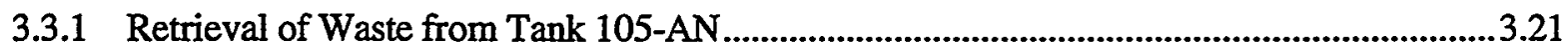

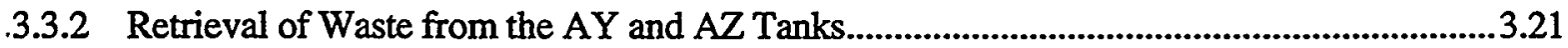

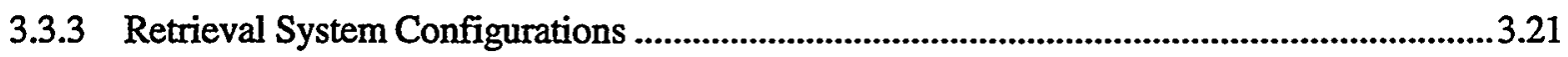


4. Selection Guidance for Devices to Enhance Sludge Removal.......................................................4.1

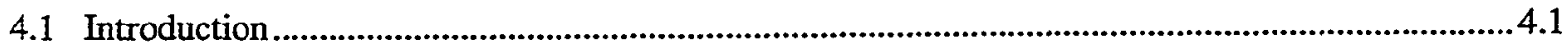

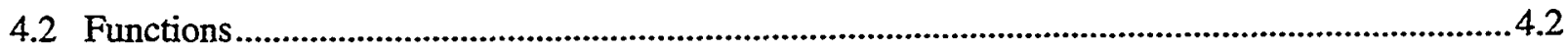

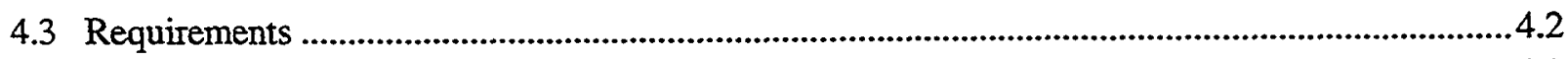

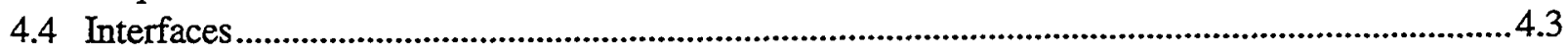

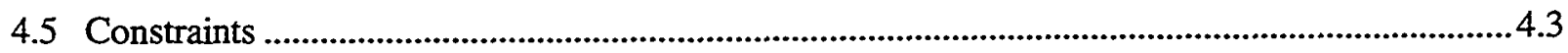

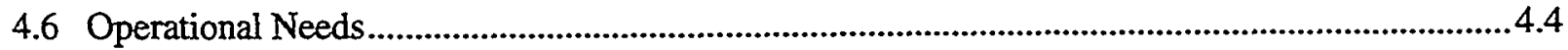

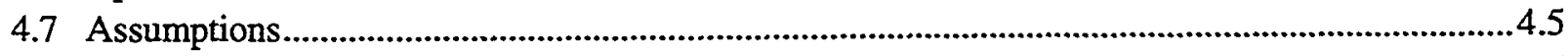

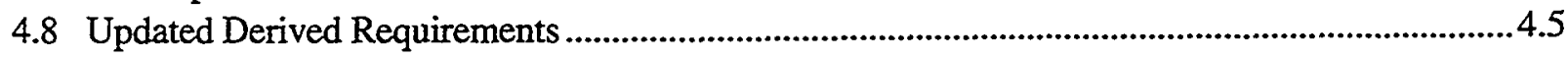

5. Evaluation of Enhanced Sludge Removal Technologies ...........................................................5.1

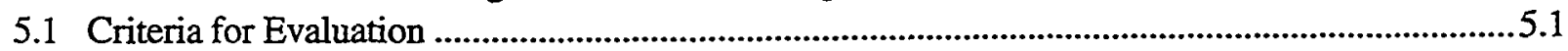

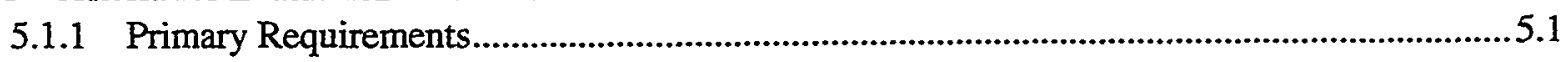

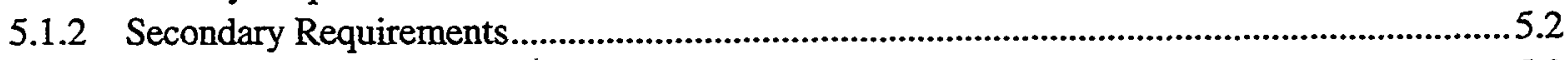

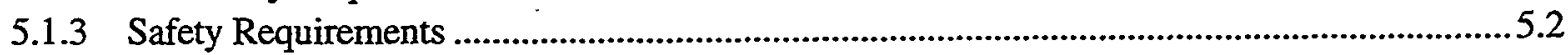

5.1.4 Design - Construction - Installation Details ....................................................................5.3

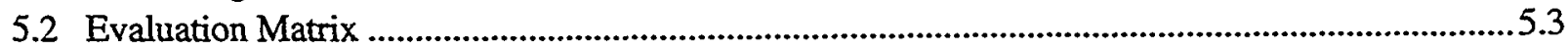

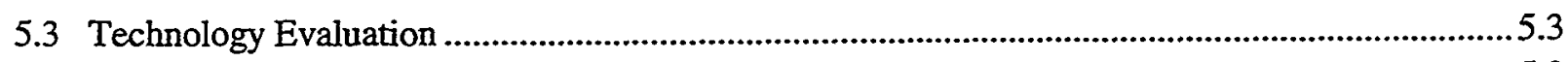

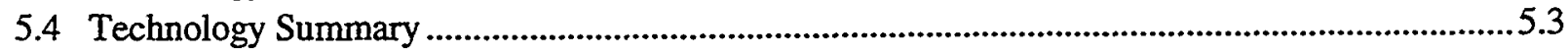

6. Deployed Technologies for Enhanced Sludge Removal ...............................................................6.1

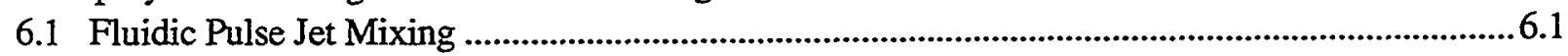

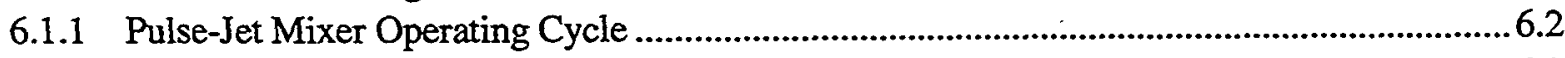

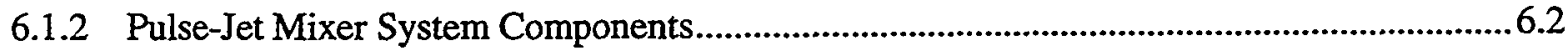

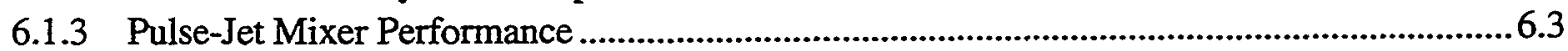

6.1.4 Pulse-Jet Mixer Deployment for Enhanced Sludge Retrieval............................................6.4

6.2 Borehole-Miner Extendible-Nozzle Sluicer..........................................................................6.4.

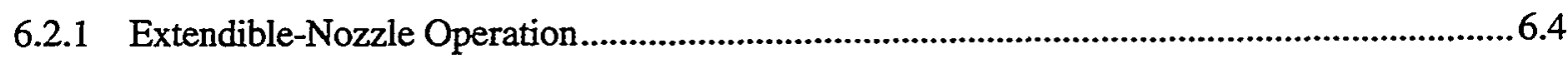

6.2.2 Extendible-Nozzle System Components .............................................................................6.4

6.2.3 ORNL Configuration Extendible-Nozzle Weight ..........................................................6.7

6.2.4 Extendible-Nozzle Operating Experience and Performance..................................................6.8

6.2.5 Extendible-Nozzle Deployment for Enhanced Sludge Removal ..........................................6.8

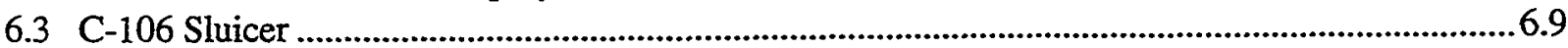

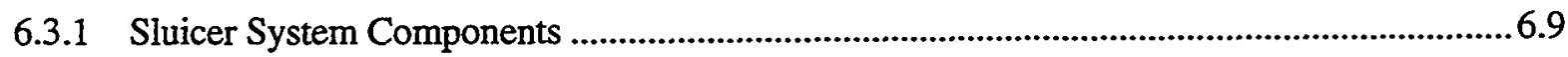

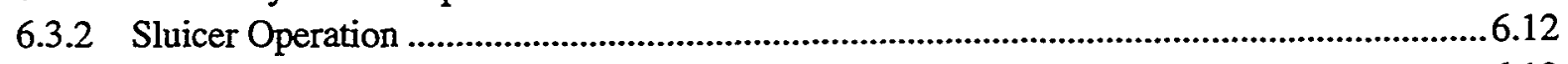

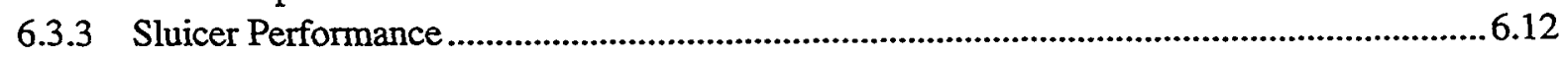

6.3.4 Sluicer Deployment for Enhanced Sludge Removal ...........................................................6.14

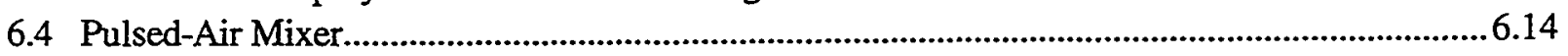

6.4.1 Pulsed-Air Mixer Operation.........................................................................................14

6.4.2 Pulsed-Air Mixer System Components.............................................................................6.15

6.4.3 Pulsed-Air Mixer Operating Experience and Performance...........................................6.18

6.4.4 Pulsed-Air Mixer Deployment for Enhanced Sludge Removal ............................................6.18

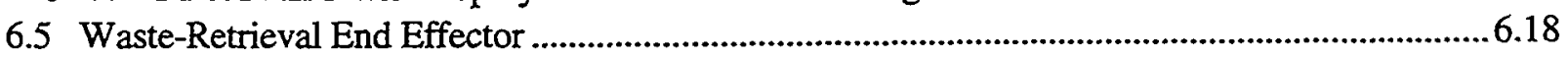

6.5.1 Waste Retrieval End-effector Operation .........................................................................6.20

6.5.2 Waste-Retrieval End-Effector System Components .......................................................6.20 


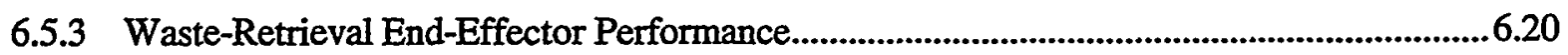

6.5.4 Waste-Retrieval End-Effector Deployment for Enhanced Sludge Removal ......................6.21

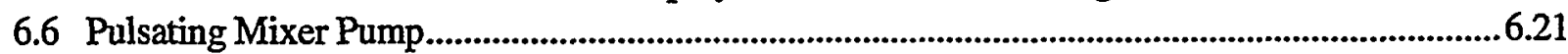

6.6.1 Pulsating Mixer Pump Components and Operation .........................................................6.21

7. Demonstrated Technologies for Enhanced Sludge Removal ........................................................... 7.1

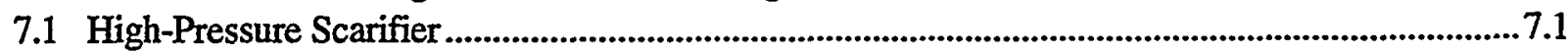

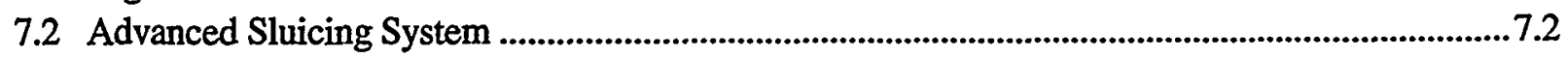

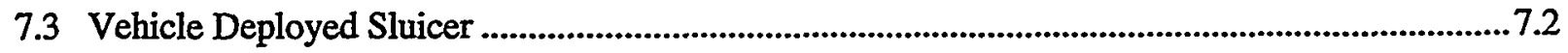

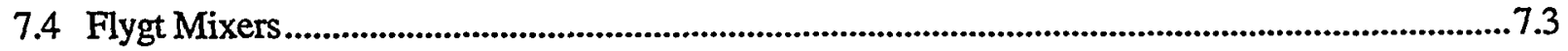

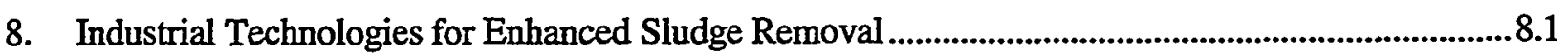

8.1 Literature Survey of Mixing Techniques for Double-Shell Tanks ................................................8.1

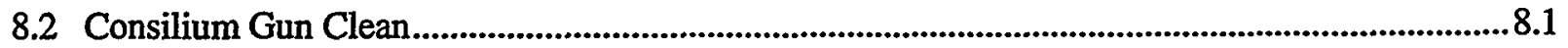

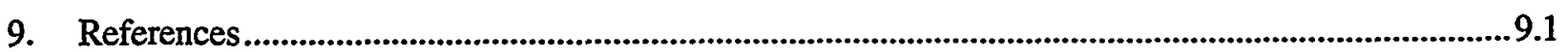




\section{Figures}

Figure 3.1 Tank farms and waste retrieval pipeline to privatization contractor site ...............................3.1

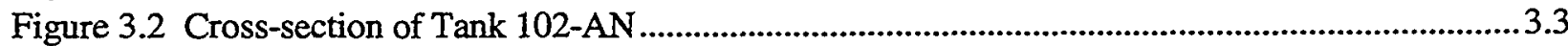

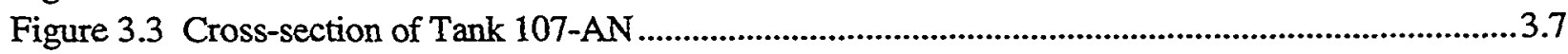

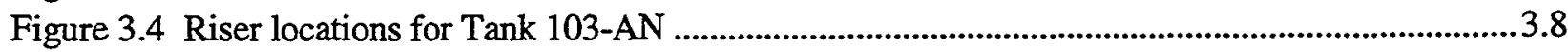

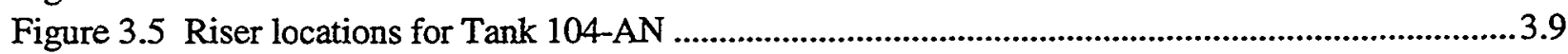

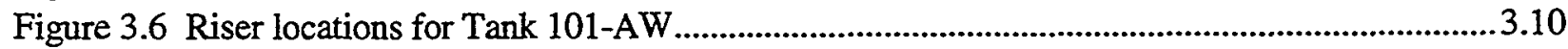

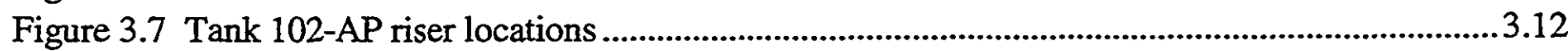

Figure 3.8 Tank 104-AP riser locations ...........................................................................................13

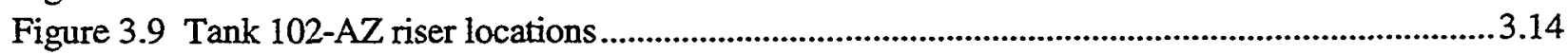

Figure 3.10 Tank 102-C riser locations ..................................................................................................16

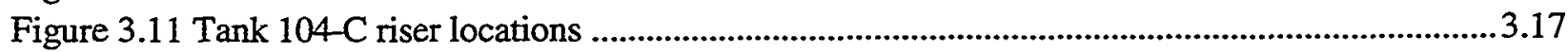

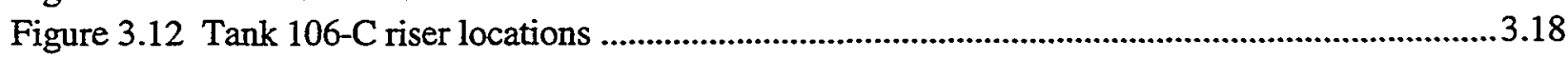

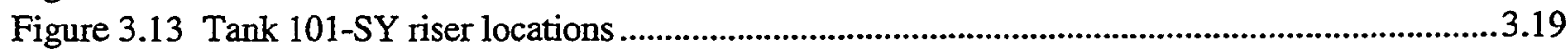

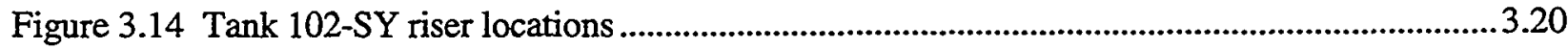

Figure 3.15 Legend for waste retrieval concepts ..............................................................................2.22

Figure 3.16 C tank waste retrieval approach.....................................................................................2.22

Figure 3.17 AN tank waste retrieval configuration..............................................................................3.23

Figure 3.18 AN tank waste retrieval configuration..........................................................................3.24

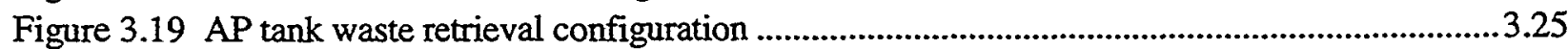

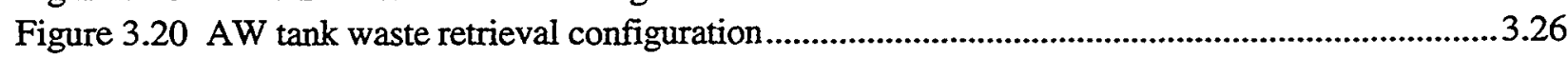

Figure 3.21 SY tank waste retrieval configuration ..........................................................................3.27

Figure 3.22 Waste retrieval configuration for $\mathrm{AY}$ tanks before and after $\mathrm{C}$ tank sluicing .....................3.28

Figure $3.23 \mathrm{AZ}$ tank waste retrieval configuration ..........................................................................3.29

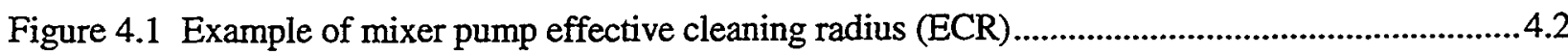

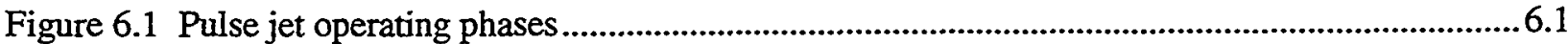

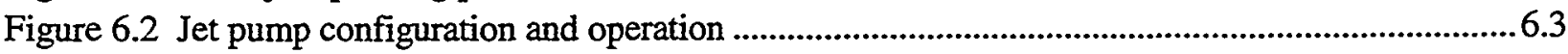

Figure 6.3 Extendible nozzle deployment and configuration ...............................................................6.5

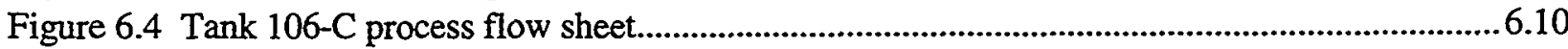

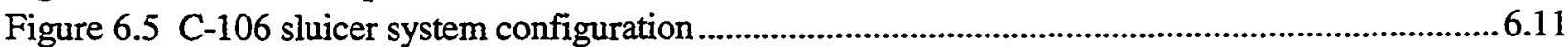

Figure 6.6 Planned sluicer operation...................................................................................................6.12

Figure 6.7 Pulsed-air bubble formation, growth, and coalescence. Courtesy of Pulseair Systems, Inc.6.15

Figure 6.8 Dual-plate pulsed-air mixer configuration.............................................................................6.15

Figure 6.9 Multiple mixer plates deployed via the inverted umbrella approach.....................................6.17

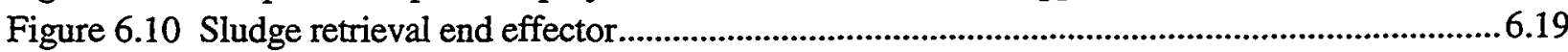

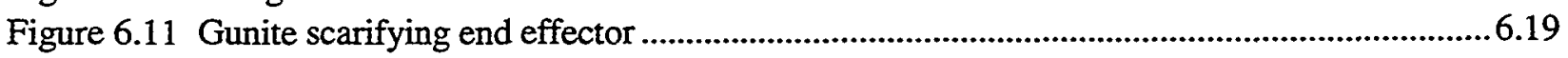

Figure 6.12 Pulsating monitor system tested at PNNL ....................................................................6.22

Figure 6.13 Diagram and dimensions of jet footprint created by pulsating mixer on tank floor...........6.24

Figure 7.1 Lightweight scarifier deployed by light duty utility arm dislodging salt-cake simulant ......... 7.1

Figure 7.2 Vehicle with sluicer attachment.............................................................................................. 7.3 


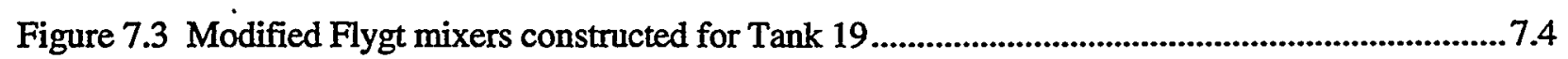

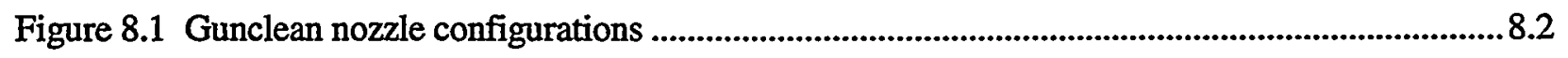




\section{Tables}

Table 2.1 Comparison of the waste mobilization technologies ............................................................2.5

Table 2.2 Comparison of the enhanced removal technologies with the acceptance criteria.....................2.8

Table 3.1 Tanks with waste to be retrieved during Phase 1 privatization................................................3.2

Table 3.2 Remediaton equipment required for each tank ....................................................................... 3.4

Table 4.1 Updated derived requirements for auxiliary solids mobilization ............................................4.5

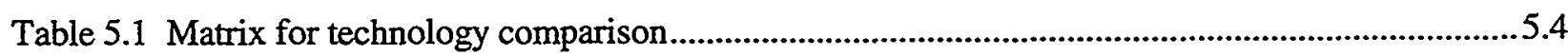

Table 5.2 Criteria for technology selection......................................................................................5.5

Table 5.3 Comparison of the waste mobilization technologies .............................................................5.6

Table 5.4 Comparison of the enhanced removal technologies with the acceptance criteria......................5.9

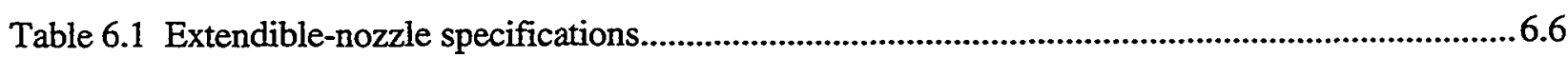

Table 6.2 History of Tank 106-C sluicing transfers..........................................................................6.13 


\section{Introduction}

Hanford needs enhanced sludge mobilization methods to retrieve sludge that is beyond the effective cleaning radius (ECR) of the baseline pair of long-shaft mixer pumps planned for mobilization of the radioactive waste stored in 23-m- (75-ft-) diameter double-shell tanks. Other sites, such as the Savannah River Site and West Valley, which also use mixer pumps in large volume tanks, may also need to implement a plan for enhanced sludge mobilization. At Hanford, this study was performed in collaboration with the River Protection Project (RPP) team to support waste feed stream treatment and immobilization.

\subsection{Background}

The River Protection Project Phase 1 project is the U.S. Department of Energy's (DOE's) plan to assure treatment of Hanford tank waste. During the 10-year minimum-order-quantity period, the facility is expected to process approximately $10 \%$ of the Hanford tank waste by mass and $20 \%$ to $25 \%$ by radioactivity.

\subsubsection{Radioactive Waste at Hanford}

Approximately $204,411 \mathrm{~m}^{3}$ (54 million gallons) of highly radioactive wastes are stored in 177 underground tanks, including 149 older single-shell tanks, at the Hanford Site in Washington State. That waste, which was derived from production of plutonium for the nation's nuclear defense program, has been accumulating at Hanford since 1944. The waste poses a serious safety concern to the public and to the environment. That risk is growing because most of the single-shell tanks have exceeded their design life. Sixty-seven of the single-shell tanks are known to have leaked, and several additional tanks are being investigated for potential leaks. Nearly $3785 \mathrm{~m}^{3}$ ( 1 million gal) of the tank waste has spilled into the soil of the vadose zone below the tanks since the first leak occurred. Recent information has indicated that tank waste radionuclides have moved through the vadose zone and now have reached the groundwater that flows under the Hanford Site, which migrates to the Columbia River.

DOE is taking active measures to reduce the chance of additional tank leaks. However, it is not possible to predict when the next tank will leak, and with passage of time, even the newer, safer doubleshell tanks are approaching the end of their design lives. Removal of the waste from the tanks, treatment, and immobilization as an inert waste form will constitute a lasting solution to the problem. DOE, the U.S. Environmental Protection Agency, and the Washington State Department of Ecology have entered into an enforceable compliance agreement setting forth milestones for cleanup of the tank waste. DOE, State regulatory agencies, and stakeholders view the tank waste cleanup as one of their top priorities. 


\subsubsection{Waste Treatment and Immobilization Approach}

In September 1996, DOE entered into contracts with two contractor teams for Phase 1 of the RPP privatization project. At the time of contract award, the contracts for RPP Phase 1 were structured into two parts: a 20-month Part A, ending in mid-1998 and an optional Part B, planned for approximately 10 to 14 years. The purpose of Part A was to evaluate the technical, operational, regulatory, business, and financial elements required by privatized facilities that would provide treatment and immobilization services on a fixed-unit-price basis. Under the original RPP Phase 1 contracts, Part B was a period, scheduled to begin in mid-1998, in which the authorized contractor(s) would fully finance, design, construct, operate, and deactivate waste treatment plants on a fixed-price basis. Based on a detailed review of the work products prepared by both contractors (as required by Part A of the contract), DOE decided to restructure Part $B$ of the contract and to authorize only one contractor, to proceed to the design phase of Phase 1. DOE concluded that the contractor proposal contained a viable conceptual facility design with robust technologies that have been effectively demonstrated at other sites and that the contractor would be able to meet contractual requirements for design, construction, and operations in the balance of Phase 1 .

In April 2000 DOE made a decision to discontinue the privatization approach for RPP after completing a review of the April 2000 deliverables submitted under the RPP privatization contract. Currently the DOE Office of River Protection is seeking competitive proposals from the private sector to design and construct a treatment and immobilization plant for the RPP at the Hanford Site near Richland, Washington.

\subsection{Scope}

This objective of this study was to support RPP's ability to deliver the Phase 1B waste feed stream for waste treatment and immobilization. Hanford needs enhanced sludge mobilization methods to retrieve sludge that is beyond the effective cleaning radius (ECR) of the baseline pair of long-shaft mixer pumps.

The scope of this task is to identify potential systems that can be installed in the double-shell tanks along with the mixer pumps, when needed to mobilize the remaining sludge. The systems will be evaluated based on this limitation incorporating knowledge of existing tank requirements and constraints. The systems will be identified and prioritized to determine whether they can be operated concurrently in tandem with mixer pumps or sequentially after mixer pumps have stopped, to move settled solids into areas influenced by mixer pumps. These auxiliary systems will further mobilize waste not under the influence of the mixer pumps or tranlocate the waste to areas of the tank that are influenced by the mixer pumps. This assessment will be integrated with similar RPP investigations. The final objective is to summarize results in a report recommending one or several types of "small systems" that can be installed in the tanks along with the mixer pumps when needed to mobilize the remaining sludge. 


\section{Conclusions and Recommendations}

The purpose of this study was to identify sludge mobilization technologies that can be readily installed in the double-shell tanks along with the mixer pumps, when mixer pump operation does not adequately mobilize the waste. The supplementary technologies will mobilize sludge that may accumulate in tank locations out-of-reach of the mixer pump jet. This study assessed the potential of the technologies to meet requirements developed for enhanced sludge removal systems.

The study proceeded in three parallel paths to identify technologies that: 1) have been previously deployed or demonstrated in radioactive waste tanks, 2) have been specifically evaluated for their ability to mobilize or dislodge waste simulants with physical and rheological properties similar to those anticipated during waste retrieval, and 3) have been used in similar industrial conditions, but not specifically evaluated for radioactive waste retrieval.

\subsection{Technologies Identified}

A series of technologies were identified that have already been deployed or are being developed for deployment to remediate radioactive waste tanks. These technologies include:

- Pulsed Air

- Pulsating Mixer Pump

- Fluidic Pulse-Jet Mixing

- C-106 Sluicer

- Borehole-Miner Extendible-Nozzle

- Waste-Retrieval End Effector

- High-Pressure Scarifier

- Flygt Mixers.

All of the technologies with the exception of Flygt mixers are based on jet mixing. The jet fluid is either air, slurry, or water. The operating parameters, jet pressure, duration and pulse rate, vary, based on the technology. Several of the technologies are very similar. The pulsating mixer pump and fluidic pulse-jet mixing both create jets by using suction to draw slurry from the tank into a tube and followed by pressure to expel the fluid jet back through the tube into the vessel. The $\mathrm{C}-106$ sluicer and the boreholeminer extendible-nozzle are both based on sluicing; however, the borehole miner operates at a higher pressure and has an increased range-of-influence from its extendible arm extension. The waste-retrieval end effector and the high-pressure scarifier are both based on scarification, with the high-pressure scarifier operating at significantly higher pressure than the waste-retrieval end effector. In contrast, the Flygt mixer uses an electrically-powered propeller surrounded by a close-fitting shroud. The propeller creates a turbulent fluid jet.

The performance of additional technologies has been evaluated for each technology's ability to mobilize or dislodge a specific type of simulated waste such as sludge, hard pan, or salt cake. Other 
technologies have been identified as promising based on industrial application in another tank cleaning environment.

\subsubsection{Pulsed-Air Mixer}

The pulsed-air mixing technique utilizes short, discrete pulses of air or inert gas to produce large bubbles near the tank floor. Air pulses injected beneath horizontal circular plates positioned just above the tank floor produce the bubbles. These bubbles rise toward the liquid surface and induce mixing; the pulse frequency, duration, gas pressure, and plate sequencing are controlled to create a well-mixed condition within the tank. In 1999, Oak Ridge National Laboratory (ORNL) deployed a pulsed-air mixer in Tank W-9 to mix waste solids and accelerate settling of $>100-\mu \mathrm{m}$-diameter particles.

\subsubsection{Pulsating Mixer Pump}

Pulsed-jet mixers such as the pulsating mixer pump have a tube or nozzle that extends to the bottom of the tank. During operation, a vacuum is created pulling fluid into the tube and into an accumulator vessel. Next, pressure is applied, and the fluid is forced back into the tank out through the bottom of the tube. As the process fluid emerges from the nozzle, the jet suspends solids and induces circulation patterns. In 1998, pulsating monitor technology, consisting of a jet mixer powered by a reciprocating air supply, was selected for deployment in Oak Ridge National Laboratory Tank TH-4 to mobilize settled solids. The system design has not been finalized.

\subsubsection{Fluidic Pulse-Jet Mixing}

Fluidic pulse-jet mixing utilizes pulse-jet agitation to mix sludge with liquid supernatant. The system mixes the sludge and supernatant via a three-phase mixing process: a suction phase, a drive phase, and a vent phase. This approach has been deployed at Oak Ridge National Laboratory to mobilize and retrieve waste from five horizontal storage tanks (W21, W22, W23, C1, and C2).

\subsubsection{C-106 Sluicer}

The Hanford Project W-320 installed the waste retrieval sluicing system (WRSS) in Tank 106-C to mobilize sludge in Tank 106-C to transfer it to Tank 102-AY. The sluicer has a 2.54-cm- (1-in.-) diameter nozzle with two degrees of motion control (rotation 194 degrees) and nozzle elevation (130 degrees). The nozzle pivots and rotates at a fixed elevation in the tank and can be aimed with a dedicated hydraulic system. The sluicer controls can be operated in manual or semi-automatic mode. The sluicer is approximately $29.2 \mathrm{~cm}$ (11.5 in.) diameter and is installed in a $30.5-\mathrm{cm}$ - (12-in.-) diameter riser. 


\subsubsection{Borehole-Miner Extendible-Nozzle}

The borehole-miner extendible-nozzle sluicer uses a semi-flexible, extendible, erectable arm to direct a high-pressure sluicer jet. The arm extension and position are controlled remotely from a control console. This system was deployed in 1998 at Oak Ridge National Laboratory to dislodge and remediate four horizontal underground radioactive waste tanks.

\subsubsection{Waste-Retrieval End Effector}

In 1997, ORNL selected a lightweight scarifying end effector, a jet-pump conveyance system, and two deployment systems: the light duty utility arm (LDUA) and the Houdini remotely operated vehicle (ROV) to perform the Gunite and Associated Tanks (GAAT) treatability study. Two scarifier end effectors were evaluated: the sludge retrieval end effector (SREE) optimized for sludge retrieval and the gunite scarifying end effector (GSEE) optimized for scarification of gunite surfaces.

\subsubsection{High-Pressure Scarifier}

A high-pressure scarifier rated to remove $0.0009 \mathrm{~m}^{3} / \mathrm{s}\left(2 \mathrm{ft}^{3} / \mathrm{min}\right)$ of waste was initially developed for dislodging and retrieval of single-shell tank waste. This system used high-pressure [379 $\mathrm{MPa}(55,000$ psi)] jets to dislodge and air conveyance to retrieve waste. During evaluation the system performed well; however, site needs changed and a lightweight version of the scarifier rated to remove $0.0005 \mathrm{~m}^{3} / \mathrm{s}(1$ $\mathrm{ft}^{3} / \mathrm{min}$ ) of waste was designed and tested. No radioactive deployments have been identified for this system.

\subsubsection{Flygt Mixers}

Shrouded axial-propeller mixers are being evaluated for deployment in Savannah River Site Tank 19 to mobilize sludge, zeolite, and salt that remain in the tank after a retrieval campaign conducted in the 1980s. The 37-kW (50-hp) mixers being considered for use in Tank 19 have a propeller diameter of 51 $\mathrm{cm}$ (20 in.) and operate at 860 rotations per minute (rpm). The spinning propeller creates a turbulent fluid jet with an average exit velocity approaching $5.4 \mathrm{~m} / \mathrm{s}(17.7 \mathrm{ft} / \mathrm{s})$.

\subsection{Technology Comparisons}

To permit comparison between the technologies, their physical and operating characteristics have been summarized in Table 2.1. Items addressed include the operating principal, ability to dislodge waste forms, and other operating characteristics. The technologies are ordered by jet pressure from low to high pressure; the Flygt mixer is listed after the fluid jet technologies. In Table 2.2, the technologies are rated with respect to meeting criteria developed for enhanced sludge removal performance. Performance is evaluated for three categories: either the technology meets the criteria, has the ability to be modified to meet the criteria, or cannot be readily modified to meet the criteria. 


\subsection{Recommendations}

Based on the acceptance criteria, one technology, the borehole-miner extendible-nozzle has the proven ability to meet key primary requirements. The borehole-miner extendible-nozzle can mobilize extremely hard waste at a distance of $3 \mathrm{~m}(10 \mathrm{ft})$ or greater. The arm extension of $3 \mathrm{~m}(10 \mathrm{ft})$, and its. ability to move back and forth can be used to sweep waste from collection piles deposited by the mixer pump back into the mixer pump path or toward the retrieval pump inlet. The current device mast is larger than the 15.2-cm- (6-in.) diameter riser; however, this could be readily modified for the application.

Two other technologies, the pulsating mixer pump and fluidic pulse-jet mixing will readily fit through a 15.2-cm- (6-in.) diameter riser; however, the technologies need to be evaluated to determine the effective cleaning radius of the specific system jets and the range of shear strengths of sludge that they can dislodge. 
Table 2.1 Comparison of the waste mobilization technologies

\begin{tabular}{|c|c|c|c|c|c|c|c|c|c|}
\hline Criteria & Pulsed Air & $\begin{array}{c}\text { Pulsating } \\
\text { Mixer Pump }\end{array}$ & $\begin{array}{c}\text { Fluidic } \\
\text { Pulse-Jet } \\
\text { Mixing }\end{array}$ & $\begin{array}{c}\text { C-106 } \\
\text { Sluicer }\end{array}$ & $\begin{array}{c}\text { Borehole- } \\
\text { Miner } \\
\text { Extendible- } \\
\text { Nozzle }\end{array}$ & $\begin{array}{c}\text { Waste- } \\
\text { Retrieval } \\
\text { End Effector }\end{array}$ & $\begin{array}{c}\text { High- } \\
\text { Pressure } \\
\text { Scariffer }\end{array}$ & Flygt Mixer & $\begin{array}{l}\text { Mixer } \\
\text { Pump }\end{array}$ \\
\hline Technique & $\begin{array}{l}\text { compressed } \\
\text { air pulses }\end{array}$ & $\begin{array}{l}\text { compressed } \\
\text { air propels } \\
\text { slurry jet }\end{array}$ & $\begin{array}{l}\text { compressed } \\
\text { air propels } \\
\text { slurry jet }\end{array}$ & $\begin{array}{l}\text { water or fluid } \\
\text { jet }\end{array}$ & $\begin{array}{l}\text { water or fluid } \\
\text { jet }\end{array}$ & water jet & water jet & $\begin{array}{l}\text { propeller } \\
\text { creates a fluid } \\
\text { jet }\end{array}$ & $\begin{array}{l}\text { high-volume } \\
\text { oscillatory } \\
\text { fluid jets }\end{array}$ \\
\hline $\begin{array}{l}\text { Jet } \\
\text { pressure }\end{array}$ & $\begin{array}{l}0.35 \text { to } 0.69 \\
\mathrm{MPa} \text { (5 to } \\
100 \mathrm{psi} \text { ) air. }\end{array}$ & $\begin{array}{l}0 \text { to } 0.69 \\
\mathrm{MPa}(0 \text { to } \\
100 \mathrm{psi})\end{array}$ & $\begin{array}{l}0 \text { to } 0.69 \\
\mathrm{MPa}(0 \text { to } \\
100 \mathrm{psi})\end{array}$ & $\begin{array}{l}\text { to } 2.07 \mathrm{MPa} \\
(300 \mathrm{psi})\end{array}$ & $\begin{array}{l}0 \text { to } 20.7 \\
\mathrm{MPa}(0 \text { to } \\
3000 \mathrm{psi})\end{array}$ & $\begin{array}{l}0 \text { to } 69 \text { or } 207 \\
\mathrm{MPa}(0 \text { to } \\
10,000 \text { or } \\
30,000 \mathrm{psi})\end{array}$ & $\begin{array}{l}379 \mathrm{MPa} \\
(55,000 \\
\text { psi) }\end{array}$ & 5 & $\begin{array}{l}\text { up to } 2.8 \\
\mathrm{MPa}(400 \\
\text { psi ) liquid }\end{array}$ \\
\hline Flow rate & $\begin{array}{l}0.005 \\
\text { standard } \\
\mathrm{m}^{3} / \mathrm{s}(10 \\
\mathrm{scfm}) \text { air } \\
\text { per plate }\end{array}$ & tbd & tbd & $\begin{array}{l}0.022 \mathrm{~m}^{3} / \mathrm{s} \\
(350 \mathrm{gal} / \mathrm{min})\end{array}$ & $\begin{array}{l}0 \text { to } 0.0095 \\
\mathrm{~m}^{3} / \mathrm{s}(0 \text { to } \\
150 \mathrm{gal} / \mathrm{min})\end{array}$ & $\begin{array}{l}0.0063 \mathrm{~m}^{3} / \mathrm{s} \\
(10 \mathrm{gal} / \mathrm{min}) \\
\text { jet }\end{array}$ & $\begin{array}{l}0.00038 \\
\mathrm{~m}^{3} / \mathrm{s}(6 \\
\mathrm{gal} / \mathrm{min}) \\
\text { ljet }\end{array}$ & $\begin{array}{l}1.1 \mathrm{~m}^{3} / \mathrm{s} \\
(17,500 \\
\mathrm{gal} / \mathrm{min})\end{array}$ & $\begin{array}{l}\text { up to } 0.315 \\
\mathrm{~m}^{3} / \mathrm{s}(5000 \\
\mathrm{gal} / \mathrm{min}) / \mathrm{jet}\end{array}$ \\
\hline $\begin{array}{l}\text { Enhances } \\
\text { dissolution }\end{array}$ & tbd & yes & yes & yes & yes & yes & yes & yes & yes \\
\hline $\begin{array}{l}\text { Mixes } \\
\text { viscous } \\
\text { liquids } \\
\end{array}$ & yes & yes & yes & yes & yes & yes & yes & yes & yes \\
\hline $\begin{array}{l}\text { Mixes } \\
\text { slurries }\end{array}$ & yes & yes & yes & yes & yes & yes & yes & yes & yes \\
\hline $\begin{array}{l}\text { Mobilizes } \\
\text { settled } \\
\text { solids }\end{array}$ & $\begin{array}{l}\text { to some } \\
\text { extent }\end{array}$ & $\begin{array}{l}\text { to some } \\
\text { extent }\end{array}$ & $\begin{array}{l}\text { to some } \\
\text { extent }\end{array}$ & $\begin{array}{l}\text { to some } \\
\text { extent }\end{array}$ & yes & yes & yes & to some extent & yes \\
\hline $\begin{array}{l}\text { Dislodges } \\
\text { solid heels }\end{array}$ & no & no & no & perhaps & yes & yes & yes & no & $\begin{array}{l}\text { if close to } \\
\text { mixer pump }\end{array}$ \\
\hline Power & $\begin{array}{l}7.5 \text { to } 15 \\
\mathrm{~kW}(10 \text { to } \\
20 \mathrm{hp})\end{array}$ & tbd & tbd & $\begin{array}{l}186 \mathrm{~kW}(250 \\
\mathrm{hp})\end{array}$ & $\begin{array}{l}149 \mathrm{~kW}(200 \\
\text { hp) }\end{array}$ & $\mathrm{tbd}$ & tbd & $37 \mathrm{~kW}(50 \mathrm{hp})$ & $\begin{array}{l}224 \mathrm{~kW}(300 \\
\mathrm{hp})\end{array}$ \\
\hline
\end{tabular}




\begin{tabular}{|c|c|c|c|c|c|c|c|c|c|}
\hline Criteria & Pulsed Air & $\begin{array}{c}\text { Pulsating } \\
\text { Mixer Pump }\end{array}$ & $\begin{array}{c}\text { Fluidic } \\
\text { Pulse-Jet } \\
\text { Mixing }\end{array}$ & $\begin{array}{l}\text { C-106 } \\
\text { Sluicer }\end{array}$ & $\begin{array}{l}\text { Borehole- } \\
\text { Miner } \\
\text { Extendible- } \\
\text { Nozzle } \\
\end{array}$ & $\begin{array}{c}\text { Waste- } \\
\text { Retrieval } \\
\text { End Effector }\end{array}$ & $\begin{array}{l}\text { High- } \\
\text { Pressure } \\
\text { Scarifier }\end{array}$ & Flygt Mixer & $\begin{array}{l}\text { Mixer } \\
\text { Pump }\end{array}$ \\
\hline $\begin{array}{l}\text { Adds heat } \\
\text { to tank } \\
\text { during } \\
\text { operation }\end{array}$ & insignificant & insignificant & insignificant & yes & yes & some & yes & yes & yes \\
\hline $\begin{array}{l}\text { Operating } \\
\text { limits }\end{array}$ & $\begin{array}{l}\text { functions at } \\
\text { all liquid } \\
\text { levels, } \\
\text { plates } \\
\text { located } \\
<2.54 \mathrm{~cm}(1 \\
\text { in.) above } \\
\text { the tank } \\
\text { floor }\end{array}$ & $\begin{array}{l}\text { functions at } \\
\text { all liquid } \\
\text { levels, nozzle } \\
\text { located }<15.2 \\
\mathrm{~cm}(6 \text { in.) } \\
\text { from floor }\end{array}$ & $\begin{array}{l}\text { functions at } \\
\text { all liquid } \\
\text { levels, } \\
\text { nozzle } \\
\text { located } \\
<15.2 \mathrm{~cm} \mathrm{(6} \\
\text { in.) from } \\
\text { floor }\end{array}$ & $\begin{array}{l}\text { functions at } \\
\text { all liquid } \\
\text { levels }\end{array}$ & $\begin{array}{l}\text { functions at } \\
\text { all liquid } \\
\text { levels }\end{array}$ & $\begin{array}{l}\text { functions at all } \\
\text { liquid levels }\end{array}$ & $\begin{array}{l}\text { functions } \\
\text { at all liquid } \\
\text { levels }\end{array}$ & $\begin{array}{l}\text { functions when } \\
\text { submerged. } \\
\text { Mixer is } 51 \mathrm{~cm} \\
\text { ( } 20 \text { in.) in } \\
\text { diameter and } \\
\text { was installed } \\
20.5 \mathrm{~cm}(8 \mathrm{in} .) \\
\text { above tank } \\
\text { floor. } \\
\text { Minimum fluid } \\
\text { depth is } 51 \mathrm{~cm} \\
(20 \text { in.) }\end{array}$ & $\begin{array}{l}\sim 1.2 \mathrm{~m}(4 \mathrm{ft}) \\
\text { head } \\
\text { required for } \\
\text { maximum } \\
\text { power. } \\
\text { Nozzle } \\
\text { centerline } \\
\sim 0.3 \text { to } 0.46 \\
\mathrm{~m}(1 \text { to } 1.5 \\
\mathrm{ft}) \text { from tank } \\
\text { bottom }\end{array}$ \\
\hline $\begin{array}{l}\text { Percent } \\
\text { secondary } \\
\text { waste } \\
\text { generated }\end{array}$ & $0 \%$ & $0 \%$ & $0 \%$ & $0 \%$ & $0 \%$ & $0 \%$ & $\begin{array}{l}0.00038 \\
\mathrm{~m}^{3} / \mathrm{s}(6 \\
\mathrm{gal} / \mathrm{min}) \\
\text { /jet }\end{array}$ & $0 \%$ & $\begin{array}{l}>0 \% \text { (some } \\
\text { seal } \\
\text { lubrication } \\
\text { water added) }\end{array}$ \\
\hline $\begin{array}{l}\text { Deploy- } \\
\text { ment }\end{array}$ & $\begin{array}{l}\text { riser mast, } \\
\text { system } \\
\text { unfolds }\end{array}$ & riser mast & riser mast & riser mast & riser arm & $\begin{array}{l}\text { arm or remote } \\
\text { vehicle }\end{array}$ & $\begin{array}{l}\text { arm or } \\
\text { remote } \\
\text { vehicle }\end{array}$ & $\begin{array}{l}\text { riser mast, } \\
\text { system unfolds }\end{array}$ & $\begin{array}{l}\text { riser mast, } \\
\text { system } \\
\text { remains } \\
\text { under riser }\end{array}$ \\
\hline $\begin{array}{l}\text { Remotely } \\
\text { deployed }\end{array}$ & yes & yes & yes & yes & yes & yes & yes & yes & yes \\
\hline
\end{tabular}




\begin{tabular}{|c|c|c|c|c|c|c|c|c|c|}
\hline Criteria & Pulsed Air & $\begin{array}{c}\text { Pulsating } \\
\text { Mixer Pump }\end{array}$ & $\begin{array}{l}\text { Fluidic } \\
\text { Pulse-Jet } \\
\text { Mixing }\end{array}$ & $\begin{array}{l}\text { C-106 } \\
\text { Sluicer }\end{array}$ & $\begin{array}{c}\text { Borehole- } \\
\text { Miner } \\
\text { Extendible- } \\
\text { Nozzle } \\
\end{array}$ & $\begin{array}{c}\text { Waste- } \\
\text { Retrieval } \\
\text { End Effector. }\end{array}$ & $\begin{array}{c}\text { High- } \\
\text { Pressure } \\
\text { Scarifier }\end{array}$ & Flygt Mixer & $\begin{array}{l}\text { Mixer } \\
\text { Pump }\end{array}$ \\
\hline $\begin{array}{l}\text { Maintain- } \\
\text { ability }\end{array}$ & $\begin{array}{l}\text { compressor } \\
\text { located } \\
\text { outside the } \\
\text { tank, plates } \\
\text { submerged } \\
\text { in waste }\end{array}$ & $\begin{array}{l}\text { valves and } \\
\text { compressor } \\
\text { located } \\
\text { outside tank }\end{array}$ & $\begin{array}{l}\text { valves and } \\
\text { compressor } \\
\text { located } \\
\text { outside tank }\end{array}$ & $\begin{array}{l}\text { pump located } \\
\text { outside of } \\
\text { tank, pump } \\
\text { may be } \\
\text { contaminated } \\
\text { based on } \\
\text { source of } \\
\text { fluid }\end{array}$ & $\begin{array}{l}\text { pump located } \\
\text { outside of } \\
\text { tank, pump } \\
\text { may be } \\
\text { contaminated } \\
\text { based on } \\
\text { source of } \\
\text { fluid }\end{array}$ & $\begin{array}{l}\text { pump located } \\
\text { outside of } \\
\text { tank, arm or } \\
\text { vehicle inside } \\
\text { tank, pump } \\
\text { may be } \\
\text { contaminated } \\
\text { based on } \\
\text { source of fluid } \\
\end{array}$ & $\begin{array}{l}\text { pump } \\
\text { located } \\
\text { outside of } \\
\text { tank arm or } \\
\text { vehicle } \\
\text { inside tank }\end{array}$ & $\begin{array}{l}\text { entire mixer } \\
\text { including } \\
\text { motor is } \\
\text { submerged }\end{array}$ & $\begin{array}{l}\text { pump motor } \\
\text { located } \\
\text { above the } \\
\text { tank riser, } \\
\text { pump } \\
\text { internals } \\
\text { submerged } \\
\text { in waste }\end{array}$ \\
\hline Removal & $\begin{array}{l}\text { system must } \\
\text { be collapsed } \\
\text { prior to } \\
\text { removal }\end{array}$ & $\begin{array}{l}\text { system } \\
\text { removed } \\
\text { through riser }\end{array}$ & $\begin{array}{l}\text { system } \\
\text { removed } \\
\text { through } \\
\text { riser } \\
\end{array}$ & $\begin{array}{l}\text { system } \\
\text { removed } \\
\text { through riser }\end{array}$ & $\begin{array}{l}\text { system } \\
\text { removed } \\
\text { through riser }\end{array}$ & $\begin{array}{l}\text { system } \\
\text { removed } \\
\text { through riser }\end{array}$ & $\begin{array}{l}\text { system } \\
\text { removed } \\
\text { through } \\
\text { riser } \\
\end{array}$ & $\begin{array}{l}\text { system must } \\
\text { be collapsed } \\
\text { prior to } \\
\text { removal } \\
\end{array}$ & $\begin{array}{l}\text { system } \\
\text { removed } \\
\text { through riser }\end{array}$ \\
\hline
\end{tabular}


Table 2.2 Comparison of the enhanced removal technologies with the acceptance criteria

\begin{tabular}{|c|c|c|c|}
\hline Number and Criteria & $\begin{array}{l}\text { Technology Meets The } \\
\text { Criteria }\end{array}$ & $\begin{array}{l}\text { Technology Can Be Modified } \\
\text { To Meet Criteria }\end{array}$ & $\begin{array}{l}\text { Technology Cannot Readily Be Modified To Meet } \\
\text { Criteria }\end{array}$ \\
\hline $\begin{array}{l}4.2 .1 \text { Assist waste } \\
\text { mobilization in dead } \\
\text { areas }\end{array}$ & $\begin{array}{l}\text { Pulsed Air } \\
\text { Pulsating Mixer Pump } \\
\text { Fluidic Pulse-Jet Mixing } \\
\text { C-106 Sluicer } \\
\text { Borehole-Miner Extendible-Nozzle } \\
\text { Waste-Retrieval End Effector } \\
\text { High-Pressure Scarifier } \\
\text { Flygt Mixer } \\
\end{array}$ & & \\
\hline $\begin{array}{l}4.3 .1 \text { Enhance } \\
\text { mobilization for a radius } \\
\text { of } 3 \mathrm{~m}(10 \mathrm{ft})\end{array}$ & $\begin{array}{l}\text { C-106 Sluicer } \\
\text { Borehole-Miner Extendible-Nozzle }\end{array}$ & $\begin{array}{l}\text { Pulsed Air } \\
\text { Pulsating Mixer Pump } \\
\text { Fluidic Pulse-Jet Mixing } \\
\text { Waste-Retrieval End Effector } \\
\text { High-Pressure Scarifier }\end{array}$ & \\
\hline $\begin{array}{l}\text { 4.3.1 Enhance } \\
\text { mobilization of } 1.96 \mathrm{kPa} \\
\left(41 \mathrm{lbf} / \mathrm{ft}^{2}\right) \text { shear } \\
\text { strength sludge }\end{array}$ & $\begin{array}{l}\text { C-106 Sluicer } \\
\text { Borehole-Miner Extendible-Nozzle } \\
\text { Waste-Retrieval End Effector } \\
\text { High-Pressure Scarifier }\end{array}$ & & $\begin{array}{l}\text { Pulsed Air } \\
\text { Pulsating Mixer Pump } \\
\text { Fluidic Pulse-Jet Mixing } \\
\text { Flygt Mixer } \\
\text { The jet performance must be evaluated to determine whether } \\
\text { mobilization of this shear strength sludge could occur at a } \\
\text { radius of } 3 m(10 \mathrm{ft})\end{array}$ \\
\hline $\begin{array}{l}4.3 .4 \text { Pass through } 15.2- \\
\mathrm{cm}-(6-\text {-in.-) diameter } \\
\text { riser }\end{array}$ & $\begin{array}{l}\text { Fluidic Pulse-Jet Mixing } \\
\text { C-106 Sluicer }\end{array}$ & $\begin{array}{l}\text { Pulsed Air } \\
\text { Pulsating Mixer Pump } \\
\text { Borehole-Miner Extendible-Nozzle }\end{array}$ & $\begin{array}{l}\text { Waste-Retrieval End Effector } \\
\text { High-Pressure Scarifier } \\
\text { Flygt Mixer } \\
\text { The design of these devices and their deployment system } \\
\text { would need to be radically modified to fit through a } 15.2-\mathrm{cm} \text { - } \\
\text { (6-in.-) diameter riser }\end{array}$ \\
\hline
\end{tabular}




\begin{tabular}{|c|c|c|c|}
\hline Number and Criteria & $\begin{array}{l}\text { Technology Meets The } \\
\text { Criteria }\end{array}$ & $\begin{array}{l}\text { Technology Can Be Modified } \\
\text { To Meet Criteria }\end{array}$ & $\begin{array}{l}\text { Technology Cannot Readily Be Modified To Meet } \\
\text { Criteria }\end{array}$ \\
\hline $\begin{array}{l}\text { 4.2.2 Detect, locate and } \\
\text { measure accumulation of } \\
\text { residual sludge }\end{array}$ & & & $\begin{array}{l}\text { Pulsed Air } \\
\text { Pulsating Mixer Pump } \\
\text { Fluidic Pulse-Jet Mixing } \\
\text { C-106 Sluicer } \\
\text { Borehole-Miner Extendible-Nozzle } \\
\text { Waste-Retrieval End Effector } \\
\text { High-Pressure Scarifier } \\
\text { Flygt Mixer } \\
\text { None of the technologies are equipped with sensors of this } \\
\text { type }\end{array}$ \\
\hline $\begin{array}{l}\text { 4.3.2 Locate waste } \\
\text { accumulated in a dead } \\
\text { area within } \pm 0.3 \mathrm{~m}(1 \mathrm{ft}) \\
\text { vertically }\end{array}$ & & & $\begin{array}{l}\text { Pulsed Air } \\
\text { Pulsating Mixer Pump } \\
\text { Fluidic Pulse-Jet Mixing } \\
\text { C-106 Sluicer } \\
\text { Borehole-Miner Extendible-Nozzle } \\
\text { Waste-Retrieval End Effector } \\
\text { High-Pressure Scarifier } \\
\text { Flygt Mixer } \\
\text { None of the technologies are equipped with sensors of this } \\
\text { type. }\end{array}$ \\
\hline $\begin{array}{l}\text { 4.5.2 Meets NFPA Class } \\
\text { 1, Div 1, Group B for } \\
\text { flammable gas tank }\end{array}$ & $\begin{array}{l}\text { Pulsed Air } \\
\text { Pulsating Mixer Pump } \\
\text { Fluidic Pulse-Jet Mixing } \\
\text { C-106 Sluicer } \\
\text { Borehole-Miner Extendible-Nozzle }\end{array}$ & $\begin{array}{l}\text { Waste-Retrieval End Effector } \\
\text { High-Pressure Scarifier }\end{array}$ & $\begin{array}{l}\text { Flygt Mixer } \\
\text { The system motor is located inside the tank. }\end{array}$ \\
\hline $\begin{array}{l}4.5 .3 \text { Does not overload } \\
\text { tanks ventilation or } \\
\text { confinement system } \\
\text { [generates }<0.047 \\
\text { standard } \mathrm{m}^{3} / \mathrm{s}(100 \mathrm{scfm}) \\
\text { aerosol] }\end{array}$ & High-Pressure Scarifier & $\begin{array}{l}\text { Pulsed Air } \\
\text { Pulsating Mixer Pump } \\
\text { Fluidic Pulse-Jet Mixing } \\
\text { C-106 Sluicer } \\
\text { Borehole-Miner Extendible-Nozzle } \\
\text { Waste-Retrieval End Effector } \\
\text { Flygt Mixer }\end{array}$ & \\
\hline
\end{tabular}




\begin{tabular}{|c|c|c|c|}
\hline Number and Criteria & $\begin{array}{l}\text { Technology Meets The } \\
\text { Criteria }\end{array}$ & $\begin{array}{l}\text { Technology Can Be Modified } \\
\text { To Meet Criteria }\end{array}$ & $\begin{array}{l}\text { Technology Cannot Readily Be Modified To Meet } \\
\text { Criteria }\end{array}$ \\
\hline $\begin{array}{l}\text { 4.5.4 Does not exceed } \\
\text { tank heat input }[22.4 \mathrm{~kW} \\
(30 \mathrm{hp})]\end{array}$ & $\begin{array}{l}\text { Pulsed Air } \\
\text { Pulsating Mixer Pump } \\
\text { Fluidic Pulse-Jet Mixing } \\
\text { C-106 Sluicer } \\
\text { Borehole-Miner Extendible-Nozzle } \\
\text { Waste-Retrieval End Effector } \\
\text { High-Pressure Scarifier } \\
\end{array}$ & & Flygt Mixer \\
\hline $\begin{array}{l}4.5 .5 \text { Does not exceed } \\
\text { dome-loading limits } \\
{[<11340 \mathrm{~kg}(25,000} \\
\mathrm{lbm})]\end{array}$ & $\begin{array}{l}\text { Pulsed Air } \\
\text { Pulsating Mixer Pump } \\
\text { Fluidic Pulse-Jet Mixing } \\
\text { C-106 Sluicer } \\
\text { Borehole-Miner Extendible-Nozzle } \\
\text { Waste-Retrieval End Effector } \\
\text { High-Pressure Scarifier } \\
\text { Flygt Mixer } \\
\end{array}$ & & \\
\hline $\begin{array}{l}\text { 4.5.7 Limited liquid } \\
\text { addition }\end{array}$ & $\begin{array}{l}\text { Pulsed Air } \\
\text { Pulsating Mixer Pump } \\
\text { Fluidic Pulse-Jet Mixing } \\
\text { C-106 Sluicer } \\
\text { Borehole-Miner Extendible-Nozzle } \\
\text { Flygt Mixer } \\
\end{array}$ & Waste-Retrieval End Effector & $\begin{array}{l}\text { High-Pressure Scarifier } \\
\text { The } 379 \mathrm{MPa}(55,000 \text { psi) intensifier pumps operate with } \\
\text { filtered water. }\end{array}$ \\
\hline
\end{tabular}




\section{Waste Feed Delivery System}

The Waste Feed Delivery System is designed to retrieve waste from 10 double-shell and 3 singleshell tanks and to deliver waste to the Vitrification Plant for conversion into glass. The waste must meet specific criteria for concentration and chemical and radionuclide content. The configuration described here was taken from the system description provided by Rasmussen (1998). The information in Rasmussen (1998) is currently being revised to reflect an updated baseline Retrieval Case 3S5 (Tedeschi 2000); however, the information presented here is typical of the proposed retrieval scenario.

\subsection{Waste Tanks}

The tanks containing waste to be retrieved are located at the Hanford Site in Washington State. The tanks are grouped in tank farms, as shown in Figure 3.1.

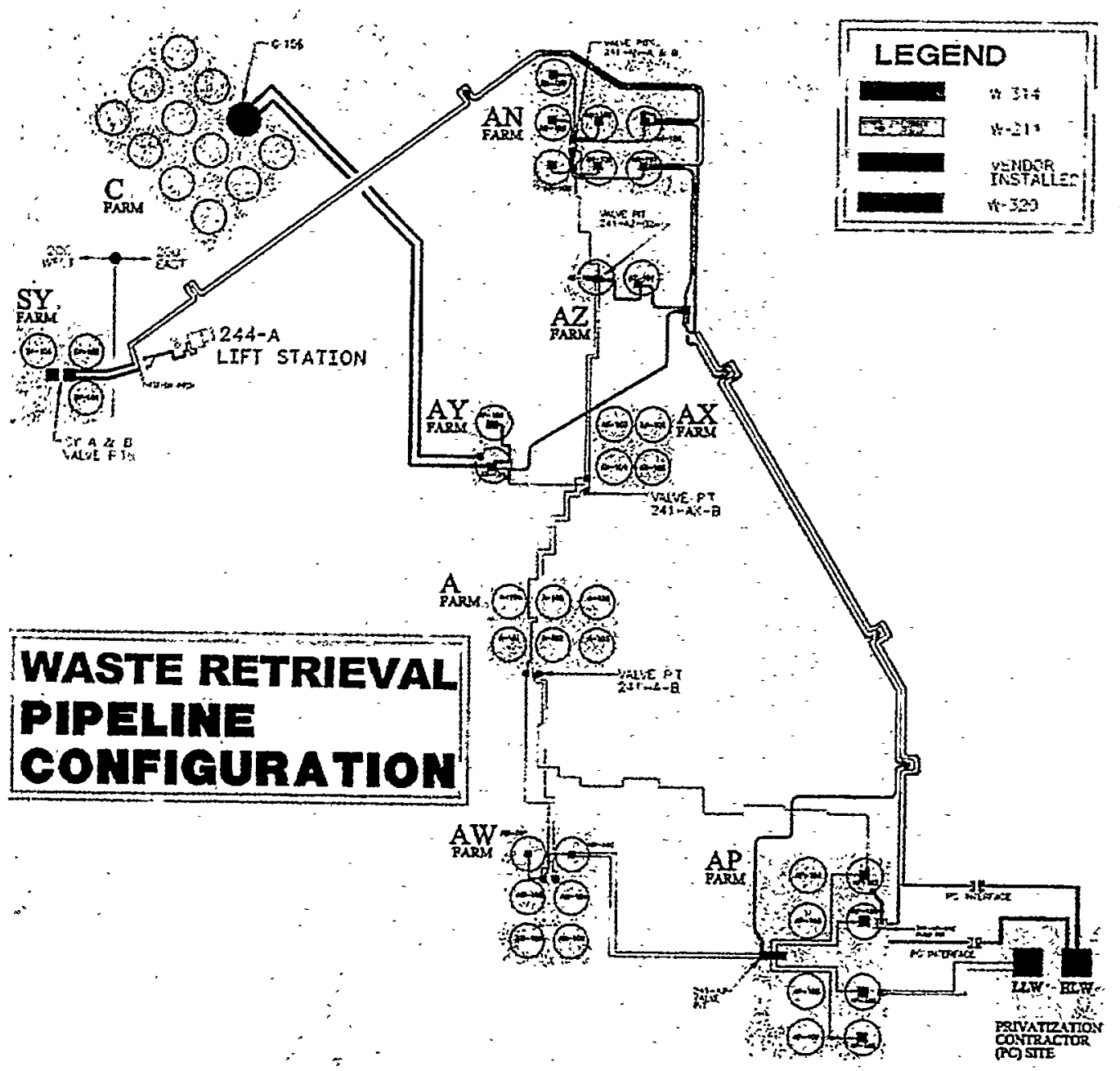

Figure 3.1 Tank farms and waste retrieval pipeline to privatization contractor site 
The characteristics of the farms and the tanks with waste to be retrieved are summarized in Table 3.1. Three of the feed source tanks are $1893-\mathrm{m}^{3}(500,000$-gal $)$ single-shell tanks and the remaining 10 tanks are $3785-\mathrm{m}^{3}$ (1-million-gal) double-shell tanks. Three single-shell and three double-shell tanks contain insoluble sludge slurries; two double-shell tanks contain saturated supernatant; and four double-shell tanks contain saturated supernatant and soluble salt that must be dissolved. The retrieval and handling techniques differ depending upon the type of tank and material to be moved. The insoluble sludge slurries are classified as high level waste (HLW) and they are processed separately from the soluble salt solutions classed as low activity waste (LAW). Retrieval of the HLW slurries may be difficult because the solids may not be fully mobilized using mixer pumps, and enhanced mobilization methods may be required.

Table 3.1 Tanks with waste to be retrieved during Phase 1 privatization

\begin{tabular}{|c|c|c|c|c|c|}
\hline Farm & $\begin{array}{l}\text { Number } \\
\text { Tanks }^{1}\end{array}$ & $\begin{array}{l}\text { Volume } \\
\mathbf{m}^{3} \text { (gal) }\end{array}$ & Risers & Service & Note \\
\hline $241-\mathrm{AN}$ & $\begin{array}{l}7 \\
102,103, \\
\mathbf{1 0 4}, 105 \\
107\end{array}$ & $\begin{array}{l}4391 \\
(1,160,000)\end{array}$ & 59 & 1981 & $\begin{array}{l}5 \text { tanks have } 59 \text { risers. The riser distribution } \\
\text { in Tank 106-AN is different from that of Tank } \\
102-, 103,104 \text {, and 105-AN. Tank } 107-\mathrm{AN} \\
\text { has } 80 \text { risers; } 21 \text { are for airlift circulators. }\end{array}$ \\
\hline $241-\mathrm{AP}$ & $\begin{array}{l}8 \\
102,104 \\
106,108\end{array}$ & $\begin{array}{l}4391 \\
(1,160,000)\end{array}$ & 71 & 1986 & $\begin{array}{l}\text { Liquid waste transfers to } 241-\mathrm{AP} \text { via } 241-\mathrm{AW} \\
\text { farm. 102-AP has additional riser for pump to } \\
\text { feed Grout Treatment Facility }\end{array}$ \\
\hline $241-A W$ & $\begin{array}{l}6 \\
101,102 \\
103,104 \\
105,106\end{array}$ & $\begin{array}{l}4391 \\
(1,160,000)\end{array}$ & 59 & 1980 & $\begin{array}{l}\text { Tanks 103-, 104-, 105-, 106-AW were } \\
\text { designed for storage of } 242-\mathrm{A} \text { feed and have } \\
\text { slurry bottoms. 101-AW feed tank is the back } \\
\text { up for } 102-\mathrm{AW} .102-\mathrm{AW} \text { feed tank is the back } \\
\text { up for 242-A evaporator; it contains a pump } \\
\text { pit and drain pit; airlift circulators and dip } \\
\text { tube to measure specific gravity. }\end{array}$ \\
\hline $241-\mathrm{AY}$ & $\begin{array}{l}2 \\
101,102\end{array}$ & & & 1971 & $\begin{array}{l}\text { Aging waste tanks. Process piping penetrates } \\
\text { the side of the tanks. Tanks contain } 22 \text { airlift } \\
\text { circulators and one steam coil }\end{array}$ \\
\hline $241-\mathrm{AZ}$ & $\begin{array}{l}2 \\
101,102\end{array}$ & $\begin{array}{l}3785 \\
(1,000,000)\end{array}$ & 105 & 1975 & $\begin{array}{l}\text { Aging waste tanks. Process piping penetrates } \\
\text { the side of the tanks. Tanks contain } 22 \text { airlift } \\
\text { circulators and one steam coil }\end{array}$ \\
\hline $241-C$ & $\begin{array}{l}12 \\
102, \mathbf{1 0 4} \\
106,107 \\
\end{array}$ & $\begin{array}{l}2006 \\
(530,000)\end{array}$ & & & Tank $106-C$ contains a sluicer nozzle. \\
\hline $241-S Y$ & $\begin{array}{l}3 \\
101,102 \\
\end{array}$ & $\begin{array}{l}4391 \\
(1,160,000)\end{array}$ & $58-59$ & 1977 & \\
\hline
\end{tabular}

\footnotetext{
${ }^{1}$ Tanks identified as a part of Retrieval Case 3S5 are shown in bold; tanks identified as having a high probability of requiring auxiliary solids mobilization are shown in bold and italics.
} 


\subsection{Tank Configurations}

Transfer operations involve tanks from AN, AP, AW, AY, AZ, C, and SY farms. Each of the tanks is unique in configuration, in-tank hardware, instrumentation, and waste type. Modifications to each tank are required prior to waste retrieval to support privatization. Details for each tank are summarized in Table 3.2 and described in the sections that follow.

\subsubsection{Tanks 102- and 107-AN}

The saturated supernatant from these two DSTs (double-shell tanks) will be pumped with water dilution at the pump intake directly to the LAW feed staging Tanks 102- and 104-AP. A cross-section of Tank 107-AN is shown in Figure 3.2. A cross-section of Tank 107-AN is shown in Figure 3.3.

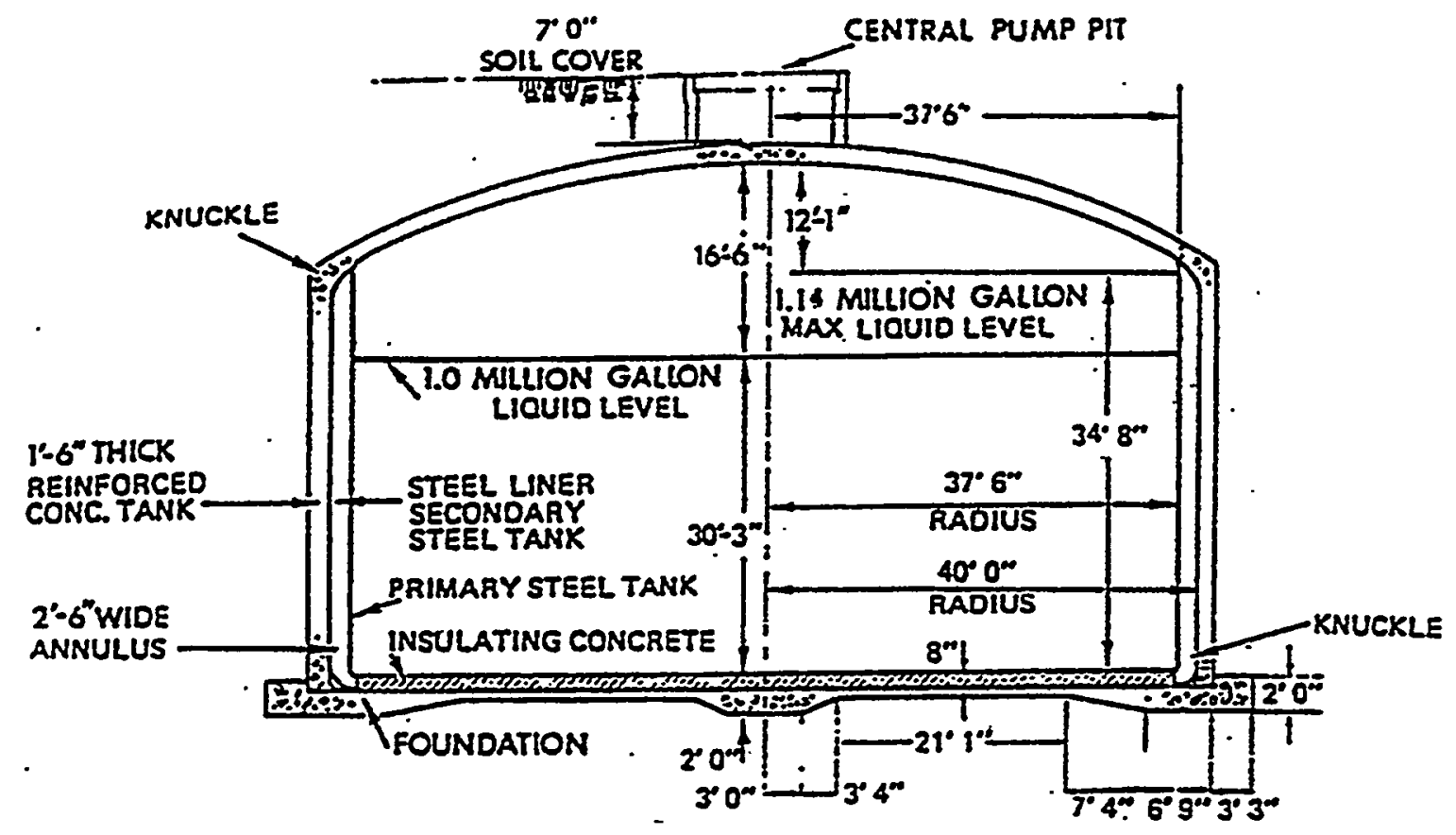

Figure 3.2 Cross-section of Tank 102-AN 
Table 3.2 Remediaton equipment required for each tank

\begin{tabular}{|c|c|c|c|c|c|c|c|c|}
\hline Tank & Type & $\begin{array}{l}\text { Bot- } \\
\text { tom }\end{array}$ & Waste & $\begin{array}{l}\text { Available Risers } \\
\text { Waste Volume }\end{array}$ & $\begin{array}{l}\text { Mixer } \\
\text { Pump }\end{array}$ & Sluicer & Transfer Pump & $\begin{array}{l}\text { In-Tank } \\
\text { Camera }\end{array}$ \\
\hline 102-AN & $\overline{\text { DST }}$ & & $\begin{array}{l}\text { Saturated } \\
\text { supernate }\end{array}$ & $\begin{array}{l}318 \mathrm{~m}^{3}(84,000 \mathrm{gal}) \text { water-soluble salt } \\
3728 \mathrm{~m}^{3}(985,000 \mathrm{gal}) \text { saturated supernatant (Rasmussen }\end{array}$ & $\begin{array}{l}\text { Not } \\
\text { required }\end{array}$ & & $\begin{array}{l}\text { Transfer pump, } \\
\text { fixed rpm, with } \\
\text { in-line dilution in } \\
\text { riser } 005\end{array}$ & $\begin{array}{l}\text { Portable if } \\
\text { required }\end{array}$ \\
\hline 103-AN & DST & flat & $\begin{array}{l}\text { Saturated } \\
\text { supernate }\end{array}$ & $\begin{array}{l}\text { 10.2-cm (4-in.) risers: } 10 \mathrm{~A}, 15 \mathrm{~A}, 21 \mathrm{~A} \\
30.5 \mathrm{~cm}(12 \text {-in.) risers: } 7 \mathrm{~B}, 12 \mathrm{~A} \\
1552 \mathrm{~m}^{3}(410,000 \mathrm{gal}) \text { water-soluble salt } \\
125 \mathrm{~m}^{3}(33,000 \mathrm{gal}) \text { floating crust } \\
\left.1949 \mathrm{~m}^{3}(515,000 \mathrm{gal}) \text { saturated liquid (Rasmussen } 1998\right) \\
\left.0.08 \mathrm{~m}^{3} \text { (20 gal) supernatant (Hanlon } 1996\right)\end{array}$ & $\begin{array}{l}\text { two 224- } \\
\mathrm{kW}(300- \\
\mathrm{hp}) \text { in } \\
\text { risers } 007 \\
\text { and } 008\end{array}$ & & $\begin{array}{l}\text { Transfer pump } \\
\text { with in-line } \\
\text { dilution in riser } \\
005\end{array}$ & In riser 12 \\
\hline 104-AN & DST & flat & $\begin{array}{l}\text { Saturated } \\
\text { supernate and } \\
\text { soluble salt }\end{array}$ & $\begin{array}{l}10.2 \mathrm{~cm} \text { (4-in.) risers: } 10 \mathrm{~A}, 15 \mathrm{~A}, 21 \mathrm{~A} \\
30.5 \mathrm{~cm}^{2}(12 \text {-in.) risers: } 12 \mathrm{~A} \\
1696 \mathrm{~m}^{3} \text { (448,000 gal) water-soluble salt } \\
125 \mathrm{~m}^{3} \text { (33,000 gal) floating crust } \\
\left.2188 \mathrm{~m}^{3} \text { (578,000 gal) supernatant (Rasmussen } 1998\right) \\
3002 \mathrm{~m}^{3} \text { (793,000 gal) supernatant } \\
\left.999 \mathrm{~m}^{3} \text { (264,000 gal) sludge (Hanlon } 1996\right)\end{array}$ & $\begin{array}{l}\text { two 224- } \\
\mathrm{kW}(300- \\
\mathrm{hp}) \text { in } \\
\text { risers } 007 \\
\text { and } 008\end{array}$ & & $\begin{array}{l}\text { Decant/transfer } \\
\text { pump with in-line } \\
\text { dilution in riser } \\
005\end{array}$ & $\begin{array}{l}\text { In riser } \\
012\end{array}$ \\
\hline $105-\mathrm{AN}$ & DST & flat & $\begin{array}{l}\text { Saturated } \\
\text { supernate and } \\
\text { soluble salt }\end{array}$ & $\begin{array}{l}1851 \mathrm{~m}^{3}(489,000 \mathrm{gal}) \text { water-soluble salt } \\
2033 \mathrm{~m}^{3} \text { (537,000 gal) supernatant } \\
\left.12.5 \mathrm{~m}^{3} \text { (33,000 gal) floating crust (Rasmussen } 1998\right)\end{array}$ & $\begin{array}{l}\text { two 224- } \\
\mathrm{kW}(300- \\
\mathrm{hp}) \text { in } \\
\text { risers } 007 \\
\text { and } 008 \\
\end{array}$ & & $\begin{array}{l}\text { Decant/transfer } \\
\text { pump with in-line } \\
\text { dilution in riser } \\
005\end{array}$ & $\begin{array}{l}\text { In riser } \\
008\end{array}$ \\
\hline $107-\mathrm{AN}$ & DST & & $\begin{array}{l}\text { Saturated } \\
\text { supernate }\end{array}$ & $\begin{array}{l}935 \mathrm{~m}^{3}(247,000 \mathrm{gal}) \text { insoluble sludge } \\
3040 \mathrm{~m}^{3}(803,000 \mathrm{gal}) \text { supernatant (Rasmussen 1998) }\end{array}$ & $\begin{array}{l}56 \mathrm{~kW}(75 \\
\mathrm{hp}) \text { in } \\
\text { central } \\
\text { pump pit }\end{array}$ & & $\begin{array}{l}\text { Transfer pump } \\
\text { with in-line } \\
\text { dilution in riser } \\
005\end{array}$ & $\begin{array}{l}\text { In existing } \\
\text { location }\end{array}$ \\
\hline
\end{tabular}




\begin{tabular}{|c|c|c|c|c|c|c|c|c|}
\hline Tank & Type & $\begin{array}{l}\text { Bot- } \\
\text { tom }\end{array}$ & Waste & $\begin{array}{l}\text { Available Risers } \\
\text { Waste Volume }\end{array}$ & $\begin{array}{l}\text { Mixer } \\
\text { Pump }\end{array}$ & Sluicer & Transfer Pump & $\begin{array}{l}\text { In-Tank } \\
\text { Camera }\end{array}$ \\
\hline 102-AP & $\overline{\text { DST }}$ & flat & $\begin{array}{l}\text { Blend and } \\
\text { verification } \\
\text { tank for LAW }\end{array}$ & $\begin{array}{l}10.2 \mathrm{~cm} \text { (4-in.) risers: } 1 \mathrm{~A}-\mathrm{C}, 15,21,27 \mathrm{~A}-\mathrm{C}, 28 \\
30.5 \mathrm{~cm}^{3}(12-\mathrm{in} .) \text { risers: } 7 \mathrm{~A}, 10 \mathrm{~A}, 12 \\
\left.4141 \mathrm{~m}^{3}(1,094,000 \mathrm{gal}) \text { supernatant (Rasmussen } 1998\right) \\
\left.4156 \mathrm{~m}^{3}(1,098,000 \mathrm{gal}) \text { supernatant (Hanlon } 1996\right)\end{array}$ & $\begin{array}{l}224 \mathrm{~kW} \\
(300 \mathrm{hp}) \\
\text { in central } \\
\text { pump pit } \\
\text { riser } 013\end{array}$ & & $\begin{array}{l}\text { Decant/transfer } \\
\text { pump with } \\
\text { adjustable suction } \\
\text { level intake in } \\
\text { riser } 015\end{array}$ & $\begin{array}{l}\text { In riser } \\
007\end{array}$ \\
\hline 104-AP & DST & flat & $\begin{array}{l}\text { Blend and } \\
\text { verification } \\
\text { tank for LAW }\end{array}$ & $\begin{array}{l}\text { 10.2-cm (4-in.) risers: } 1 \mathrm{~A}-\mathrm{C}, 15,21,27 \mathrm{~A}-\mathrm{C}, 28 \\
30.5-\mathrm{cm} \text { (12-in.) risers: 7A, 10A, } 12 \\
852 \mathrm{~m}^{3}(225,000 \text { gal) supernatant (Rasmussen } 1998) \\
\left.98 \mathrm{~m}^{3} \text { (26,000 gal) supernatant (Hanlon } 1996\right)\end{array}$ & $\begin{array}{l}224 \mathrm{~kW} \\
(300 \mathrm{hp}) \\
\text { in central } \\
\text { pump pit } \\
\text { riser } 013\end{array}$ & & $\begin{array}{l}\text { Decant/transfer } \\
\text { pump with } \\
\text { adjustable level } \\
\text { intake in riser } 015\end{array}$ & $\begin{array}{l}\text { In riser } \\
007\end{array}$ \\
\hline 106-AP & DST & & $\begin{array}{l}\text { Vitrification } \\
\text { plant feed } \\
\text { tank } \\
\end{array}$ & & & & & \\
\hline 108-AP & DST & & $\begin{array}{l}\text { Vitrification } \\
\text { plant wash } \\
\text { waste } \\
\text { accumulator }\end{array}$ & & $\begin{array}{l}\text { Probably } \\
\text { not } \\
\text { required }\end{array}$ & & $\begin{array}{l}\text { New - could use } \\
\text { pump } \\
\text { recirculation with } \\
\text { movable } \\
\text { discharge nozzle } \\
\text { instead of mixer } \\
\text { pump }\end{array}$ & \\
\hline 101-AW & DST & flat & $\begin{array}{l}\text { Saturated } \\
\text { supernate and } \\
\text { soluble salt }\end{array}$ & $\begin{array}{l}10.2 \mathrm{~cm} \text { (4-in.) risers: } 10 \mathrm{~A}, 13 \mathrm{~A}, 15 \mathrm{~A}, 16 \mathrm{~A} \\
30.5 \mathrm{~cm}^{3}(12 \text {-in.) risers: } 7 \mathrm{~B}, 12 \mathrm{~A}, 24 \mathrm{~A}-\mathrm{B} \\
1158 \mathrm{~m}^{3}(306,000 \mathrm{gal}) \text { water-soluble salt } \\
125 \mathrm{~m}^{3}(33,000 \mathrm{gal}) \text { floating crust } \\
\left.2975 \mathrm{~m}^{3}(786,000 \mathrm{gal}) \text { saturated supernate (Rasmussen } 1998\right) \\
3952 \mathrm{~m}^{3}(1,044,000 \mathrm{gal}) \text { supernatant } \\
\left.318 \mathrm{~m}^{3}(84,000 \mathrm{gal}) \text { sludge (Hanlon } 1996\right)\end{array}$ & $\begin{array}{l}\text { two } 224 \\
\mathrm{~kW}(300 \\
\mathrm{hp}) \text { in } \\
\text { risers } 007 \\
\text { and } 008\end{array}$ & & $\begin{array}{l}\text { Transfer pump } \\
\text { with in-line } \\
\text { dilution in riser } \\
005\end{array}$ & $\begin{array}{l}\text { In riser } \\
012\end{array}$ \\
\hline 102-AY & DST & & Sludge & $\begin{array}{l}83 \mathrm{~m}^{3}(22,000 \mathrm{gal}) \text { sludge } \\
3017 \mathrm{~m}^{3}(797,000 \mathrm{gal}) \text { supernatant (Rasmussen) }\end{array}$ & & & $\begin{array}{l}\text { Sluicing/transfer } \\
\text { Bottom or } 6.1 \mathrm{~m} \\
(20 \mathrm{ft}) \text { elevation in } \\
\text { riser } 6 \mathrm{~A}\end{array}$ & $\begin{array}{l}\text { In riser } \\
24 \mathrm{~A}\end{array}$ \\
\hline
\end{tabular}




\begin{tabular}{|c|c|c|c|c|c|c|c|c|}
\hline Tank & Type & $\begin{array}{l}\text { Bot- } \\
\text { tom }\end{array}$ & Waste & $\begin{array}{l}\text { Available Risers } \\
\text { Waste Volume }\end{array}$ & \begin{tabular}{|l|} 
Mixer \\
Pump \\
\end{tabular} & Sluicer & Transfer Pump & \begin{tabular}{|l|} 
In-Tank \\
Camera \\
\end{tabular} \\
\hline 101-AZ & DST & 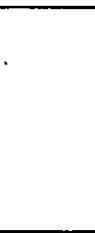 & Sludge & $\begin{array}{l}155 \mathrm{~m}^{3}(41,000 \mathrm{gal}) \text { sludge } \\
\left.3172 \mathrm{~m}^{3}(838,000 \mathrm{gal}) \text { supernatant (Rasmussen } 1998\right)\end{array}$ & $\begin{array}{l}\text { two } 224 \\
\mathrm{~kW}(300 \\
\mathrm{hp}) \text { in } \\
\text { risers 1B } \\
\text { and ID } \\
\end{array}$ & & $\begin{array}{l}\text { Transfer pump } \\
\text { with in-line } \\
\text { dilution (without } \\
\text { flexible suction } \\
\text { intake) in riser } 6 \mathrm{~A} \\
\end{array}$ & In riser $7 \mathrm{~B}$ \\
\hline 102-AZ & DST & flat & Sludge & $\begin{array}{l}\text { 10.2-cm (4-in.) risers: } 5 \mathrm{~B}, 11 \mathrm{~A} \\
\text { 15.2-cm (6-in.) risers: } 15 \mathrm{~A}-\mathrm{L} \\
394 \mathrm{~m}^{3}(104,000 \text { gal) sludge } \\
2854 \mathrm{~m}^{3}(754,000 \text { gal) supernatant (Rasmussen } 1998) \\
3142 \mathrm{~m}^{3}(830,000 \text { gal) supernatant } \\
\left.360 \mathrm{~m}^{3} \text { (95,000 gal) sludge (Hanlon } 1996\right)\end{array}$ & $\begin{array}{l}\text { two } 224 \\
\mathrm{~kW}(300 \\
\mathrm{hp}) \text { in } \\
\text { risers 1B } \\
\text { and 1D }\end{array}$ & & $\begin{array}{l}\text { Transfer pump } \\
\text { with flexible } \\
\text { suction intake and } \\
\text { in-line dilution in } \\
\text { riser } 6 \mathrm{~A}\end{array}$ & In riser 7B \\
\hline $102-\mathrm{C}$ & SST & & Sludge & $1196 \mathrm{~m}^{3}(316,000 \mathrm{gal})$ sludge (Rasmussen 1998$)$ & & Sluicer & New transfer & \\
\hline 104-C & SST & & Sludge & $1117 \mathrm{~m}^{3}(295,000$ gal) sludge (Rasmussen 1998$)$ & & Sluicer & New transfer & \\
\hline $106-\mathrm{C}$ & SST & & & $\begin{array}{l}227 \mathrm{~m}^{3}(60,000 \mathrm{gal}) \text { high-heat generating sludge } \\
522 \mathrm{~m}^{3}(138,000 \mathrm{gal}) \text { low-heat generating sludge (Rasmussen } \\
\text { 1998) }\end{array}$ & & Sluicer & $\begin{array}{l}\text { Submersible } \\
\text { slurry pump and } \\
\text { booster pump }\end{array}$ & \\
\hline 101-SY & DST & flat & $\begin{array}{l}\text { Salt slurry } \\
\text { from mixing } \\
\text { saturated } \\
\text { supernate and } \\
\text { soluble salt }\end{array}$ & $\begin{array}{l}10.2-\mathrm{cm}(4 \mathrm{in} .) \text { risers } 11 \mathrm{~A}, 17 \mathrm{~B}, 22 \mathrm{~A}, 23 \mathrm{~A} \\
30.5-\mathrm{cm}(12 \text {-in. risers } 7 \mathrm{~A}, 13 \mathrm{~A} \\
155 \mathrm{~m}^{3}(41,000 \mathrm{gal}) \text { water-soluble salt } \\
10 \text { to } 125 \mathrm{~m}^{3}(2750 \text { to } 33,000 \text { gal) floating crust } \\
4270 \mathrm{~m}^{3}(1,128,000 \mathrm{gal}) \text { saturated slurry } \\
4062 \mathrm{~m}^{3}(1,073,000 \mathrm{gal}) \text { supernatant } \\
\left.155 \mathrm{~m}^{3}(41,000 \mathrm{gal}) \text { sludge (Hanlon } 1996\right)\end{array}$ & $\begin{array}{l}112 \mathrm{~kW} \\
(150 \mathrm{hp}) \\
\text { submers- } \\
\text { ible-motor } \\
\text { in riser } \\
12 \mathrm{~A}\end{array}$ & & $\begin{array}{l}\text { New transfer } \\
\text { pump with in-line } \\
\text { dilution }\end{array}$ & $\begin{array}{l}\text { In riser } \\
5 \mathrm{~A}\end{array}$ \\
\hline 102-SY & DST & flat & $\begin{array}{l}\text { Insoluble } \\
\text { sludge; } \\
\text { sluiced if } \\
\text { needed for } \\
\text { pre-staging } \\
\text { SY-101 waste }\end{array}$ & $\begin{array}{l}10.2-\mathrm{cm}(4 \mathrm{in} .) \text { risers } 11 \mathrm{~A}, 17 \mathrm{~B}, 22 \mathrm{~A}, 23 \mathrm{~A} \\
30.5-\mathrm{cm}^{3}(12-\mathrm{in} .) \text { risers } 7 \mathrm{~A}, 13 \mathrm{~A} \\
1976 \mathrm{~m}^{3}(522,000 \mathrm{gal}) \text { supernatant } \\
269 \mathrm{~m}^{3}(71,000 \mathrm{gal}) \text { sludge }\end{array}$ & $\begin{array}{l}\text { two } 224 \\
\mathrm{~kW}(300 \\
\mathrm{hp}) \text { in } \\
\text { risers 5A- } \\
\mathrm{B}\end{array}$ & & $\begin{array}{l}\text { New transfer } \\
\text { pump with in-line } \\
\text { dilution in riser } \\
\text { 3A }\end{array}$ & $\begin{array}{l}\text { In riser } \\
12 \mathrm{~A}\end{array}$ \\
\hline
\end{tabular}




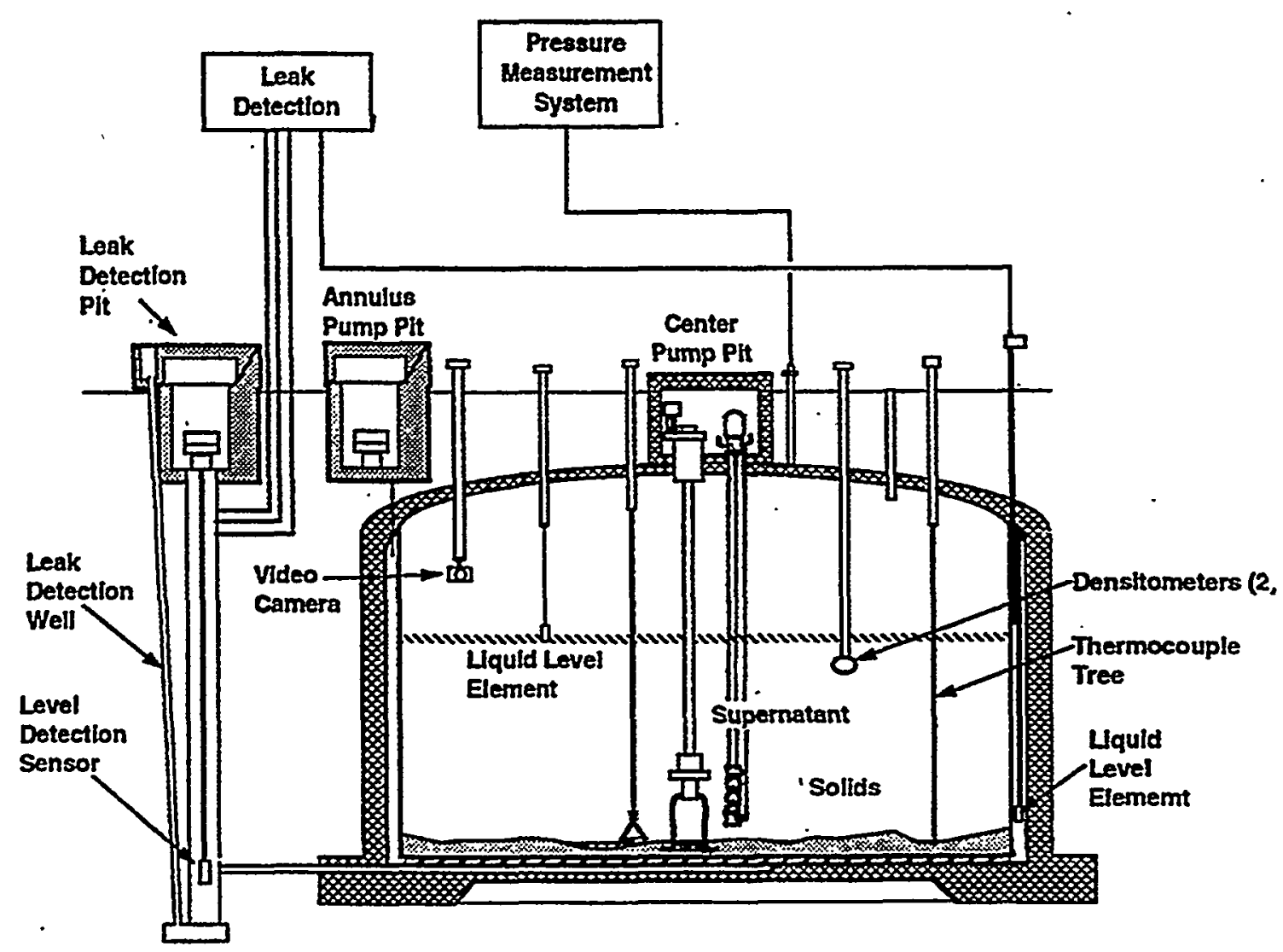

Figure 3.3 Cross-section of Tank 107-AN

\subsubsection{Tanks 103-, 104-, and 105-AN and 101-AW}

These four LAW tanks contain saturated supernatant and large volumes [up to $6.1 \mathrm{~m}(20 \mathrm{ft})$ ] of soluble salt. Each tank will be equipped with two $224 \mathrm{~kW}(300-\mathrm{hp})$ mixer pumps and a new transfer pump with in-line dilution as a part of project W-211 scope. The salt will be dissolved using heated water or dilute sodium hydroxide and delivered as a liquid to LAW feed staging Tanks 102- and 104-AP. Tank 103-AN riser details are presented in Figure 3.4. Tank 104-AN riser details are presented in Figure 3.5. Tank 101-AW riser locations are summarized in Figure 3.6. 

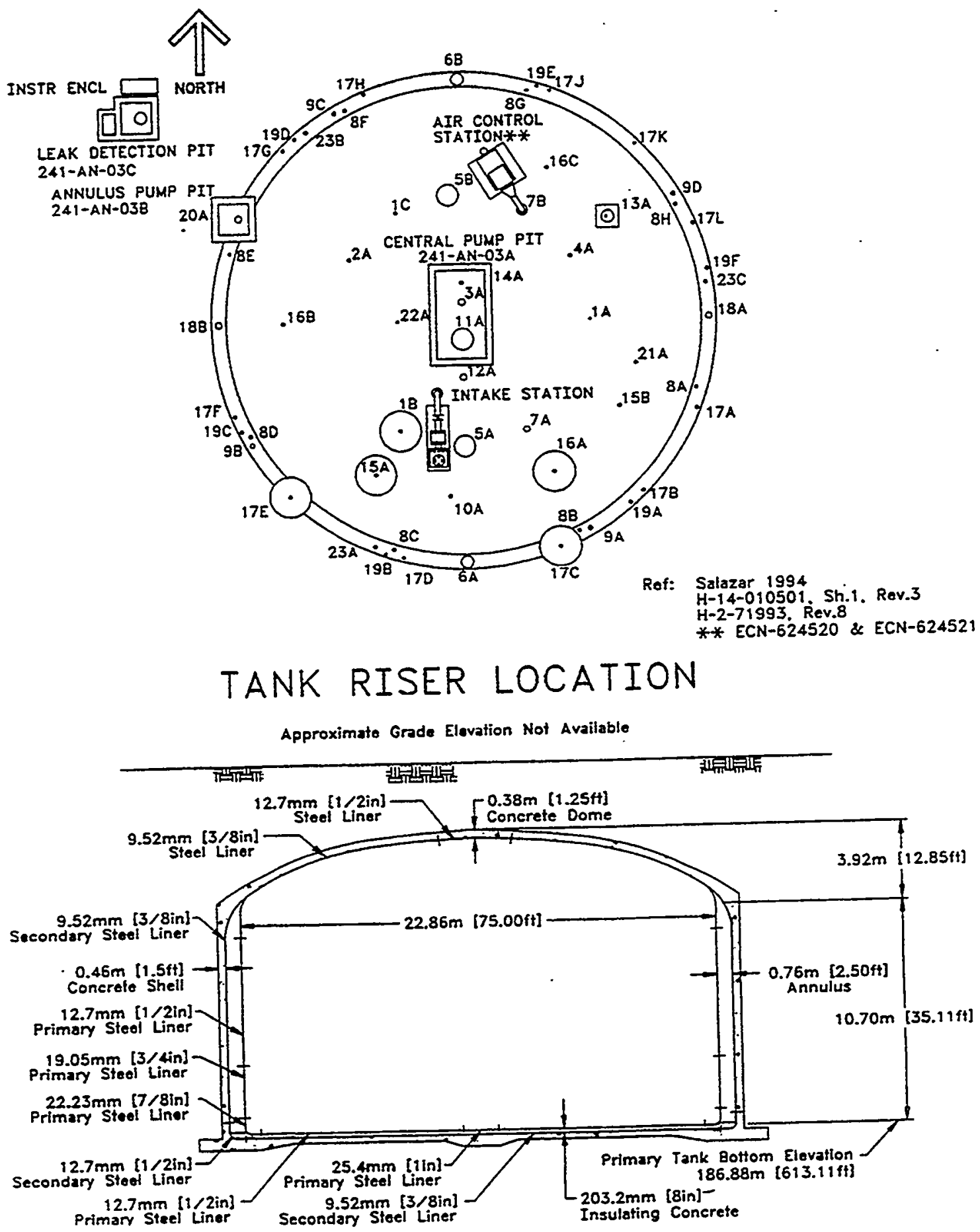

Figure 3.4 Riser locations for Tank 103-AN 


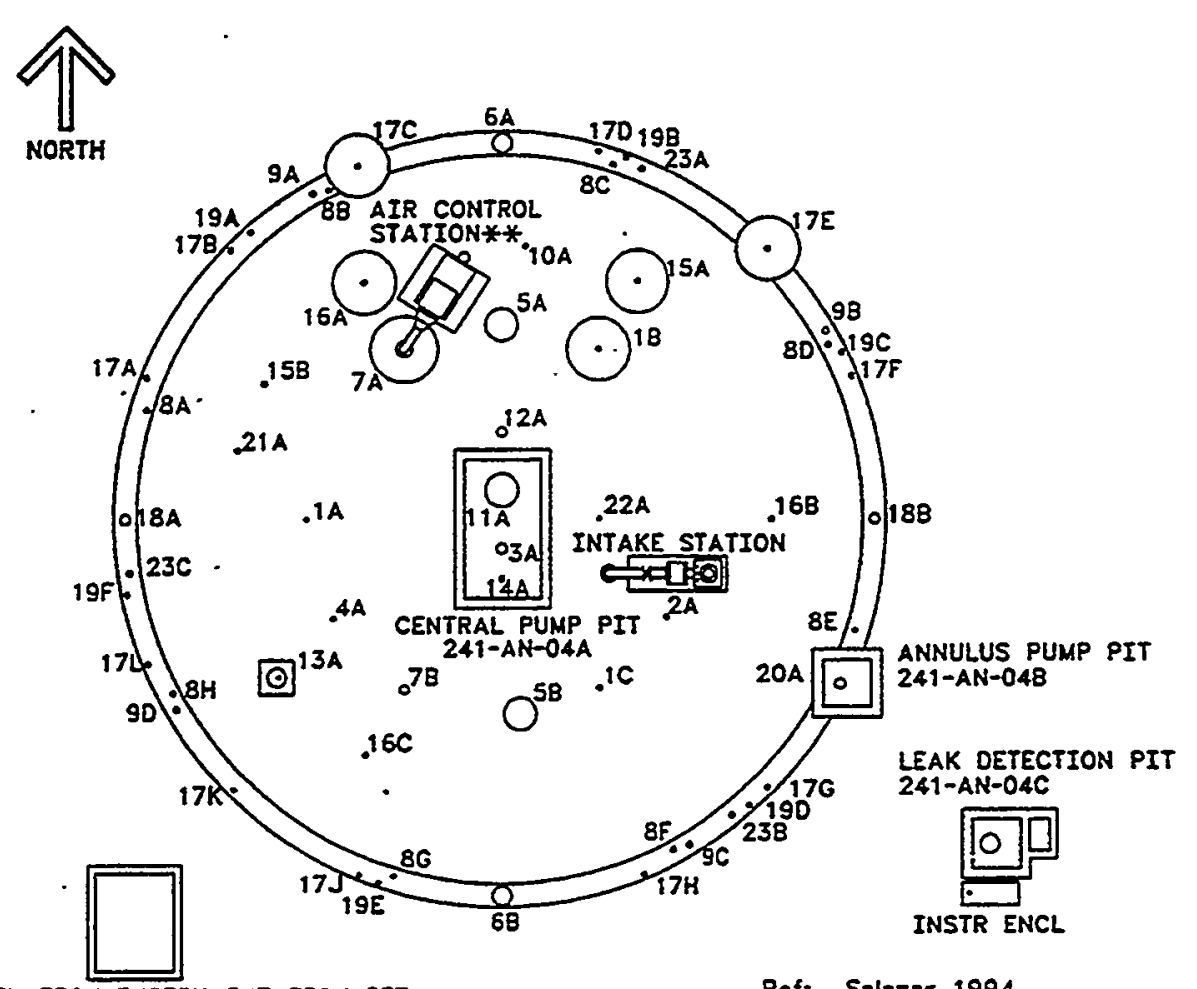

VENTILATION INSTRUMENTATION PIT

Rof: Salazar 1994

H-14-010501. Sh.1. Rev.3

H-2-71994 Rev 10

** ECN-624520 \& ECN-624521

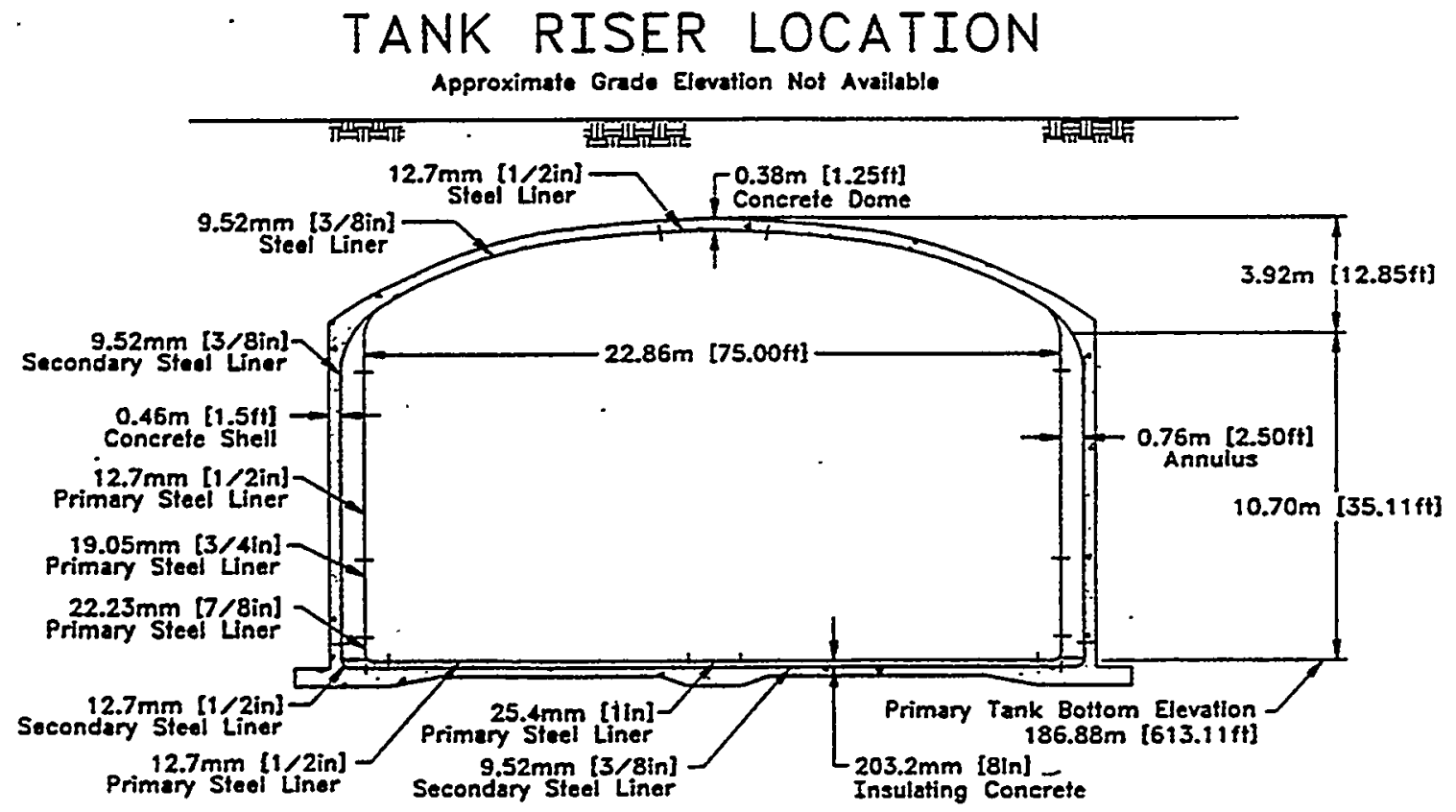

Figure 3.5 Riser locations for Tank 104-AN 


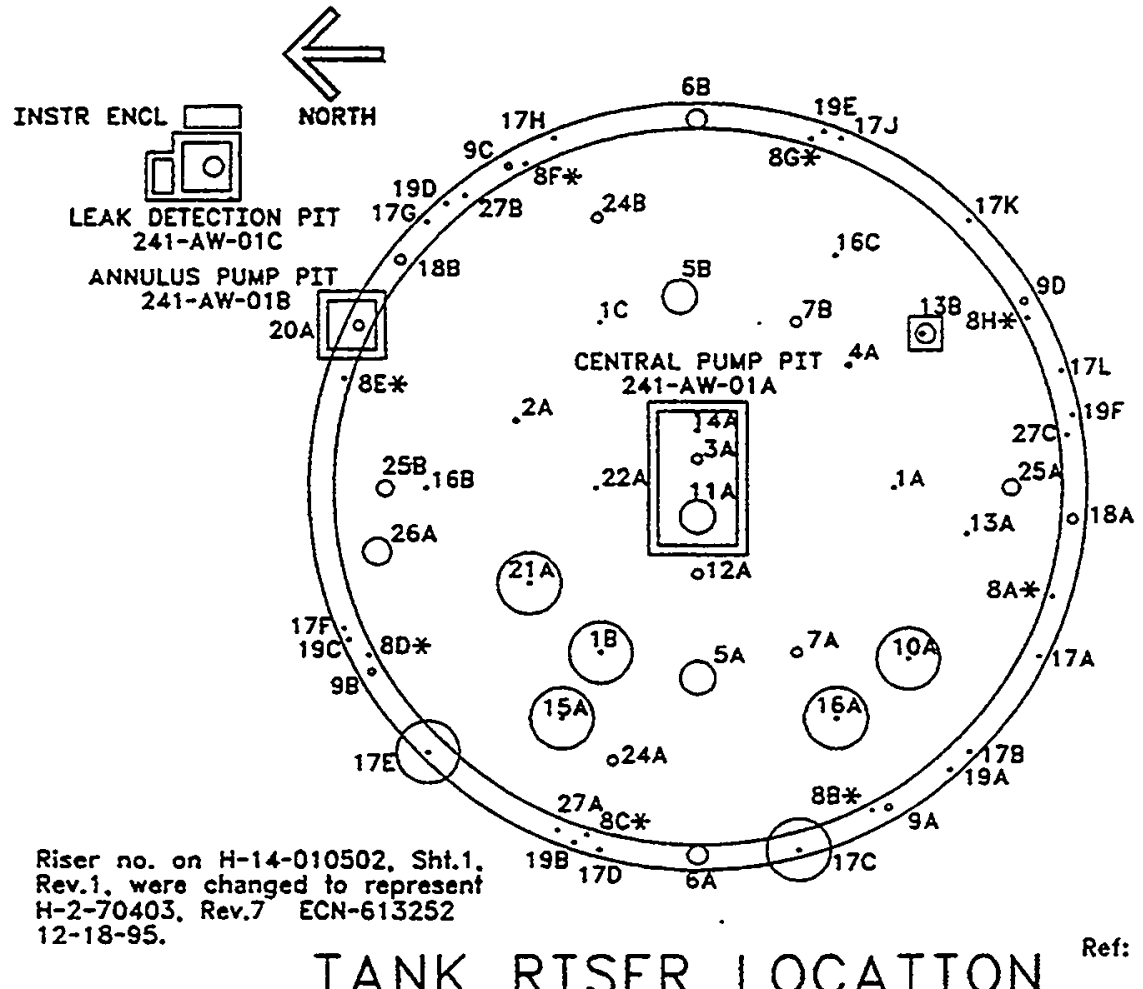

Salazar 1994

H-14-010502 Sh.1. Re H-2-70403, Rov.7

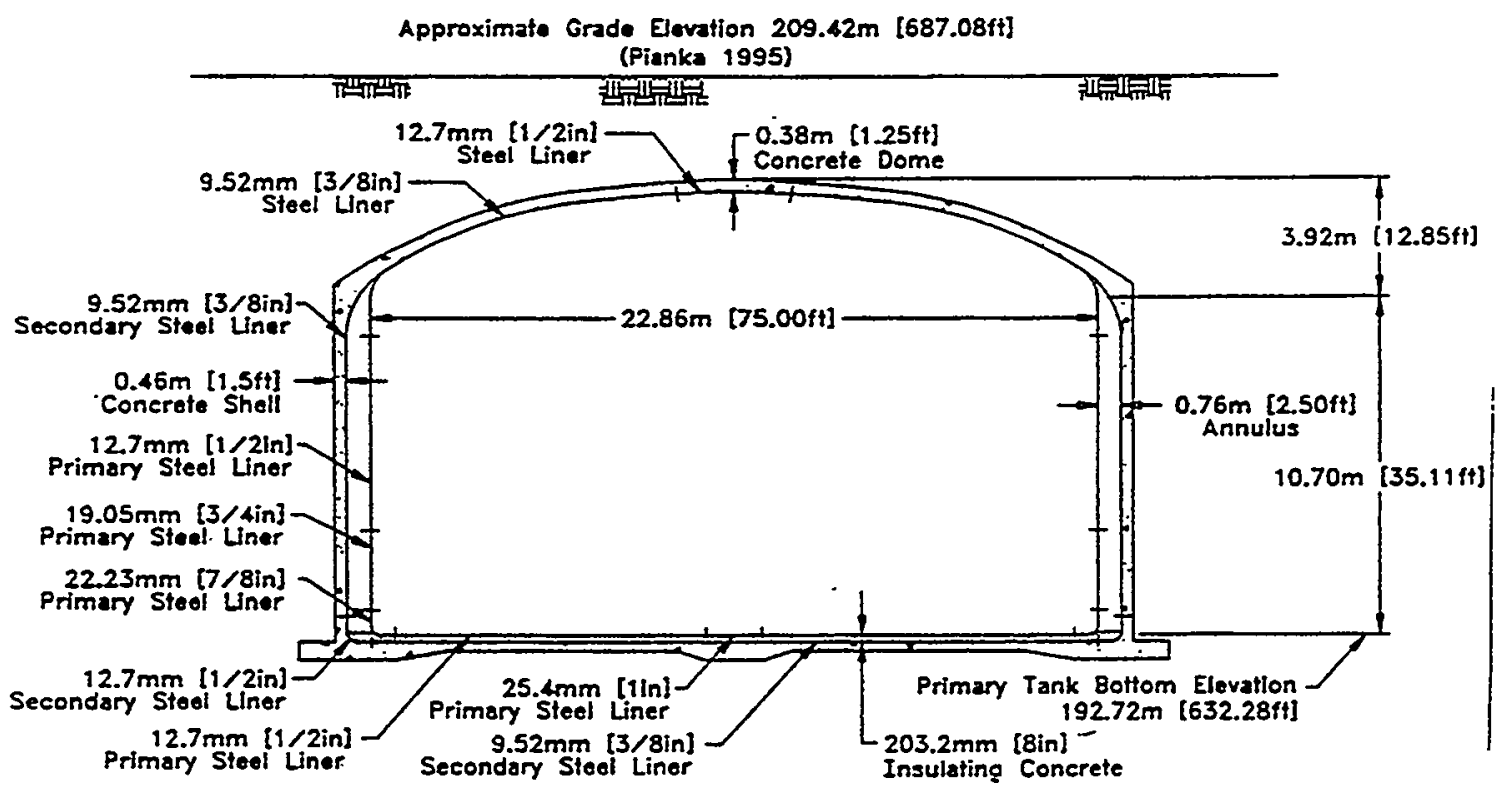

Figure 3.6 Riser locations for Tank 101-AW 


\subsubsection{Tanks 102- and 104-AP}

These two tanks will be used as blending and verification tanks for LAW only; HLW will be pumped directly to the vitrification plant. Solutions in 102- and 104-AP will be blended and chemically adjusted before pumping to the vitrification plant feed Tank 106-AP. For these operations, each tank will be equipped with a 224-kW (300-hp) mixer pump and a new transfer pump. Tank 102-AP riser locations are summarized in Figure 3.7. Tank 104-AP riser locations are summarized in Figure 3.8.

\subsubsection{Tank 106-AP}

This tank will be taken over by the vitrification plant to serve as their feed tank.

\subsubsection{Tank 108-AP}

This tank will receive the vitrification plant wash waste from Tanks 101- and 102-AZ.

\subsubsection{Tank 102-AY}

This tank contains HLW sludge and is scheduled to receive sludge from Tank 106-C. When the 106$C$ sludge-retrieval operation is completed, existing equipment will be removed and the tank will be equipped with four 112-kW (150-hp) mixer pumps installed in the four sluice pits and a combination sluicing/slurry transfer pump in the central pump pit. The new pump will have a valved intake to draw from either the tank bottom for transferring slurry to the vitrification plant or from the $6.1-\mathrm{m}(20-\mathrm{ft})$ level for sluicing Tanks 104- and 102-C. The sluicing schedule includes sending slurry to the vitrification plant three times: after slucing Tank 106-C, the waste will be slurried to Tank 101-AZ; after sluicing Tank 104-C, tank waste from 102-AY will be slurried to 102-AZ; and after sluicing Tank 102-C, tank slurry from 102-AY will be pumped directly to the vitrification plant.

\subsubsection{Tanks 101- and 102-AZ}

The sludge in these two tanks will be suspended using existing supernatant with two new mixer pumps. The resulting HLW slurry will be pumped to the vitrification plant in small batches. The vitrification plant will separate and wash the sludge and pump the wash solution to Tank 108-AP as LAW feed. Tank 102-AZ riser locations are summarized in Figure 3.9. 


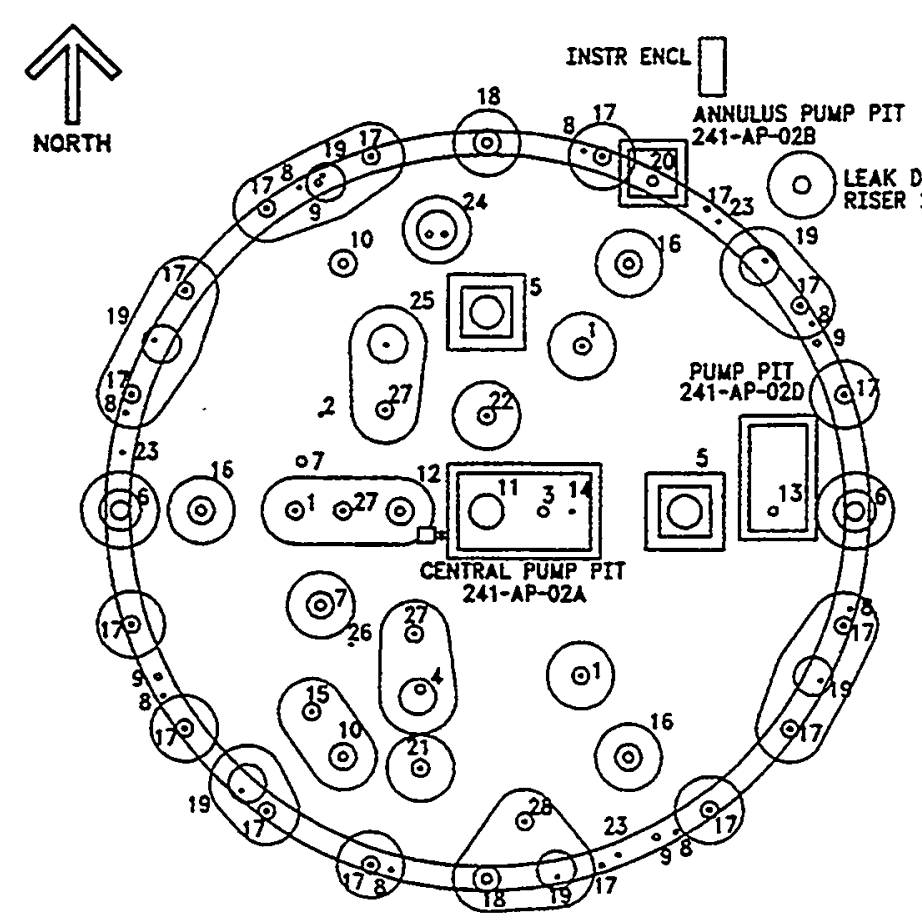

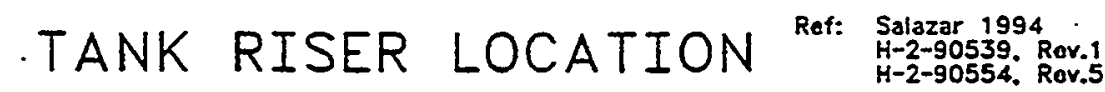

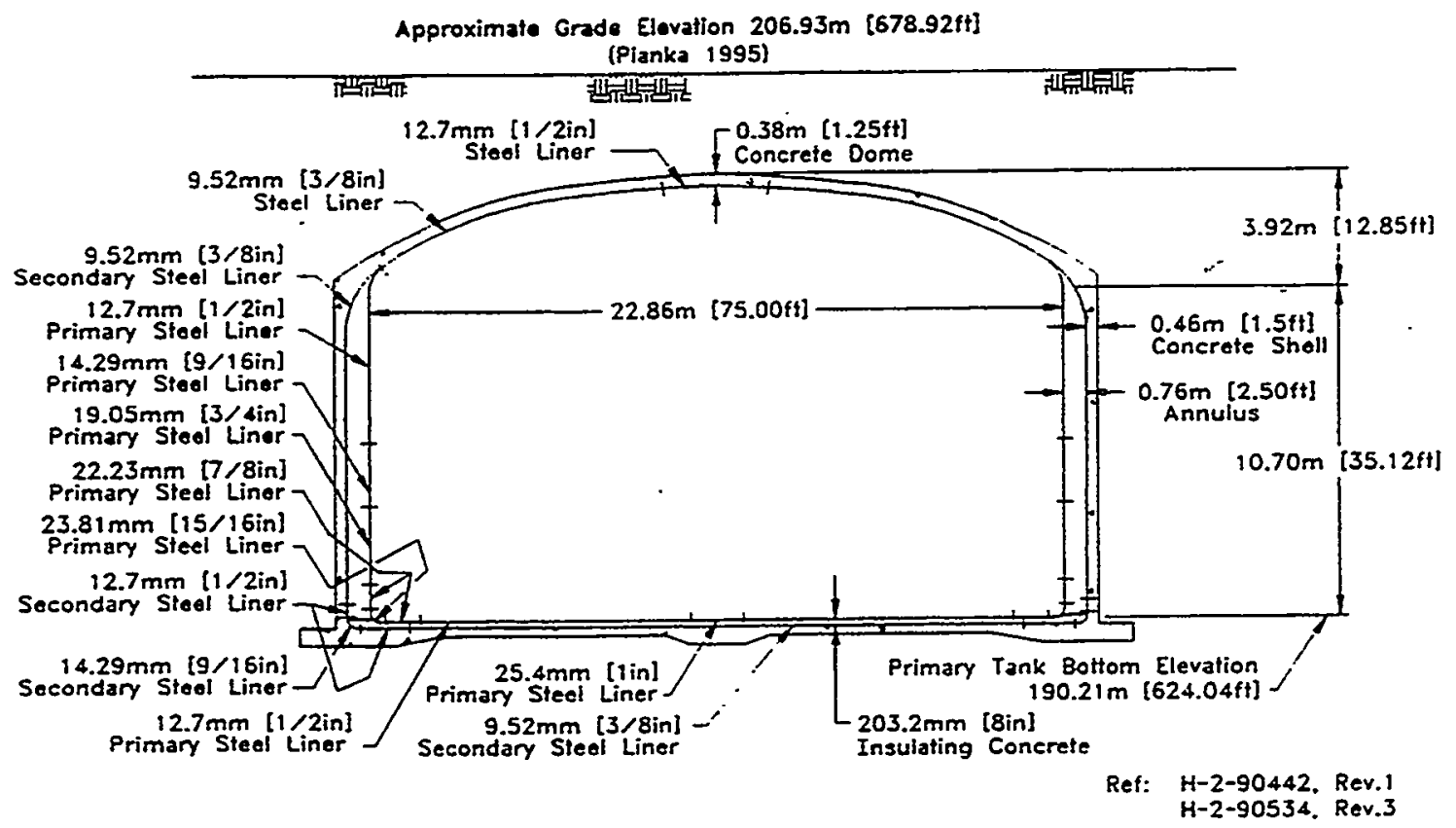

Figure 3.7 Tank 102-AP riser locations 

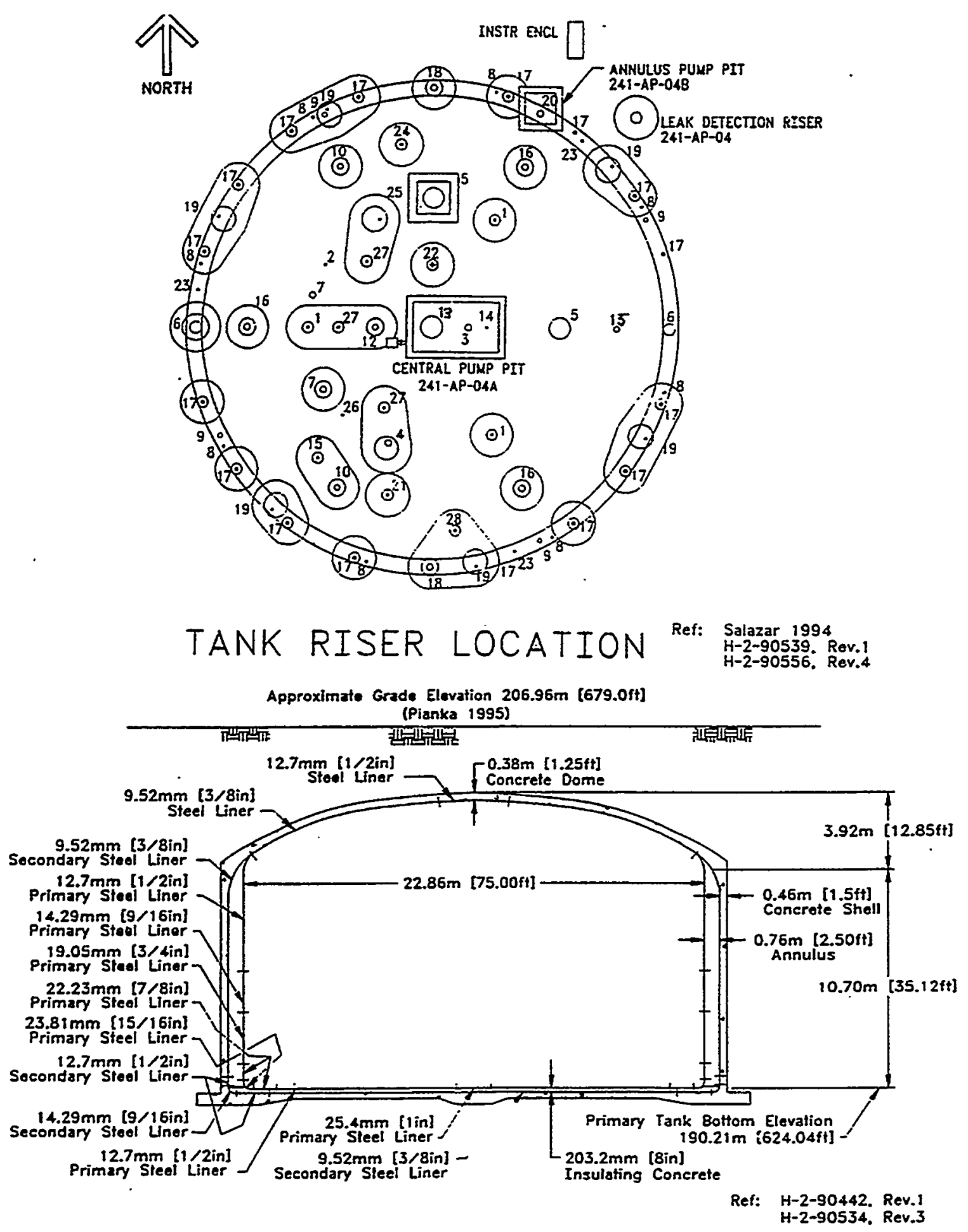

Figure 3.8 Tank 104-AP riser locations 


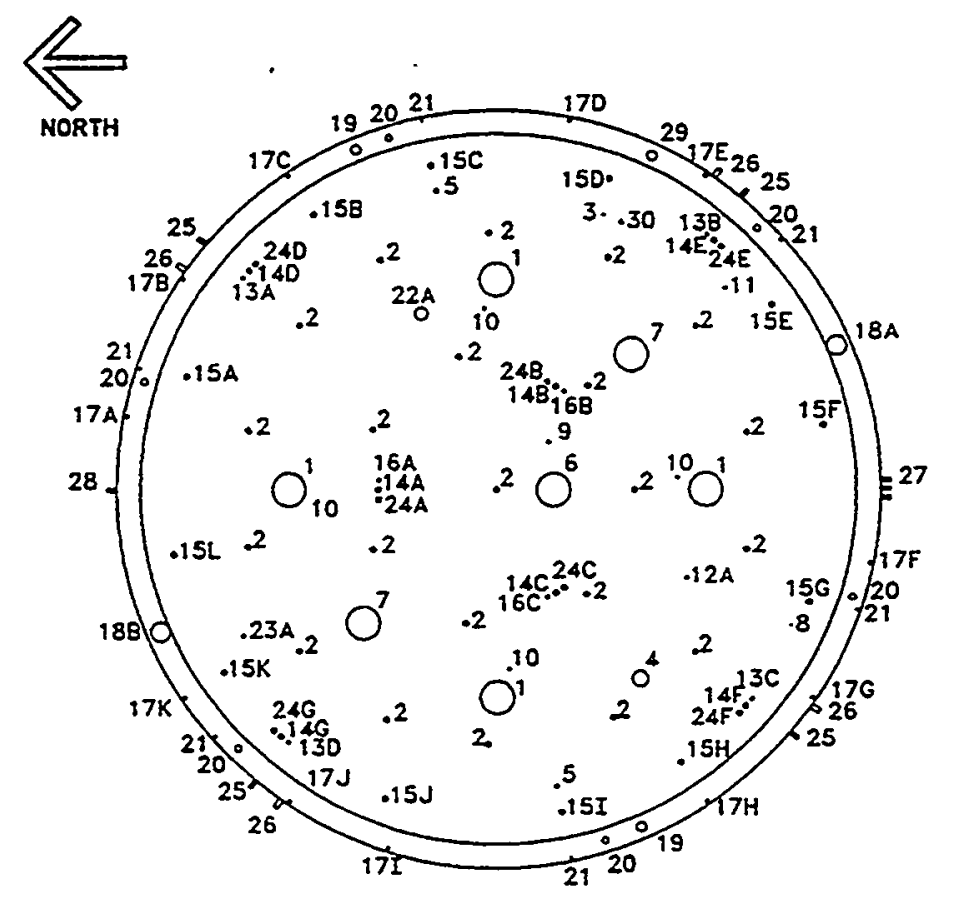

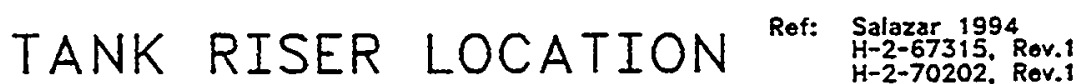

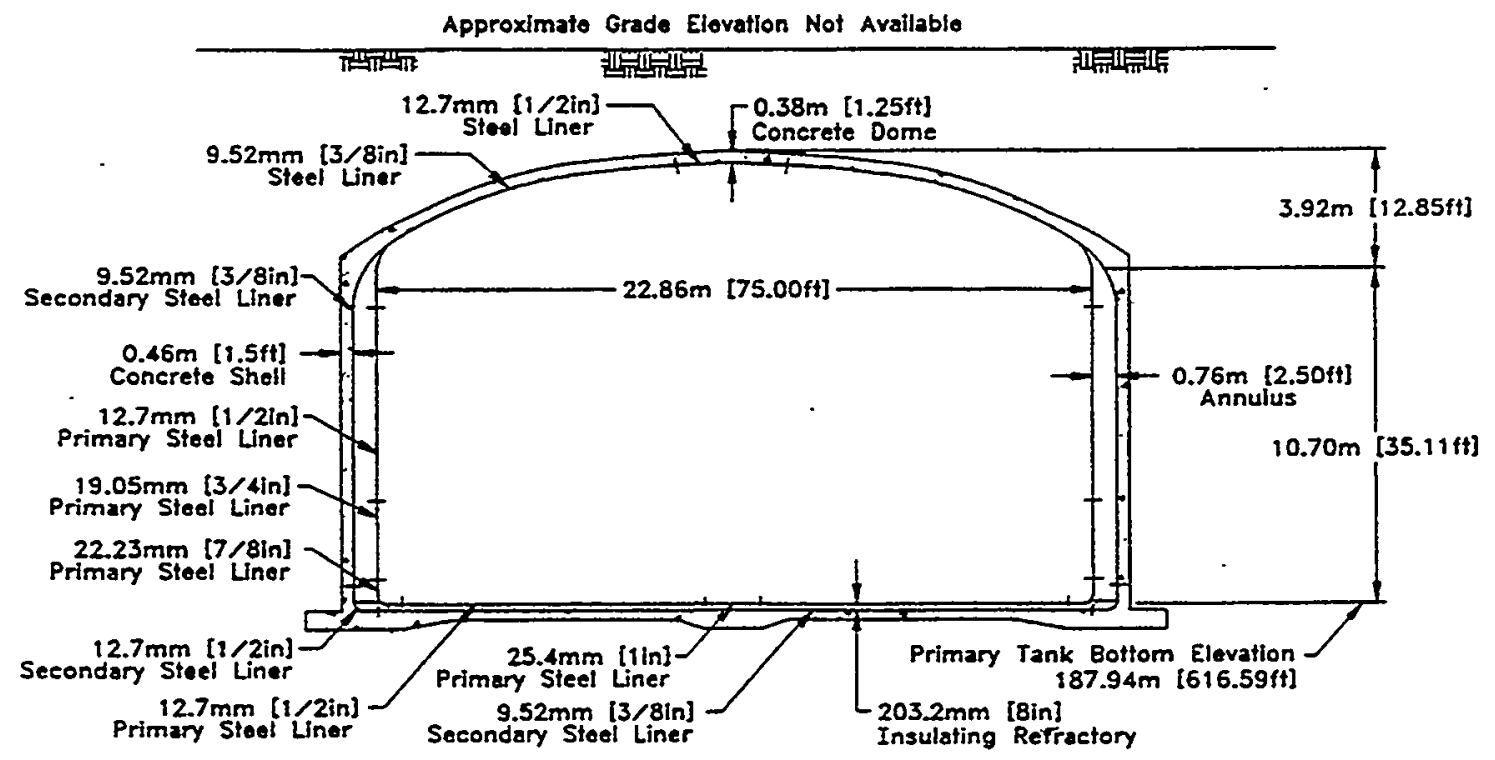

Figure 3.9 Tank 102-AZ riser locations 


\subsubsection{Tanks 102-, 104-, and 106-C}

These three HLW single-shell sludge tanks will be sluiced to Tank 102-AY. Tank 102-AY will be slurried out after receiving each tank batch. Tank 102-C riser locations are summarized in Figure 3.10. Tank 104-C riser locations are summarized in Figure 3.11. Tank 106-C riser locations are summarized in Figure 3.12.

\subsubsection{Tank 101-SY}

Tank 101-SY contains a $155-\mathrm{m}^{3}(41,000$-gal) layer of water-soluble salt covered by a floating crust that varies in thickness from a few $\mathrm{cm}$ to a $\mathrm{m}$ (in. to a ft). Gas buildup in the salt layers resulted in periodic tank pressurization that necessitated installation and operation of the mixer pump to ensure slow gas venting. This waste is maintained in suspension by periodic operation of a $112-\mathrm{kW}(150-\mathrm{hp})$ submersible-motor mixer pump. A new transfer pump with in-line dilution will be installed to dissolve and transfer the slurry to Tank 102-SY. The existing mixer pump will be used to aid in diluting and mixing the tank waste for transfer. Tank 101-SY riser locations are summarized in Figure 3.13.

\subsubsection{Tank 102-SY}

Tank SY-102 is not included as a feed-material tank for Phase 1 of vitrification. This tank contains insoluble sludges that will be cleaned out to allow Tank SY-101 to be slurried into Tank SY-102, where the 101-SY supernatant and dissolved salts will be adjusted for proper concentration before shipment through the cross-site transfer line to the vitrification feed tanks. The current inventory in Tank 102-SY will be slurried to Tank 105-AW via Tank 104-AN using the high-pressure cross-site line. Two mixer pumps and a new in-line dilution transfer pump will be installed in Tank 102-SY. SY-102 riser locations are summarized in Figure 3.14. 


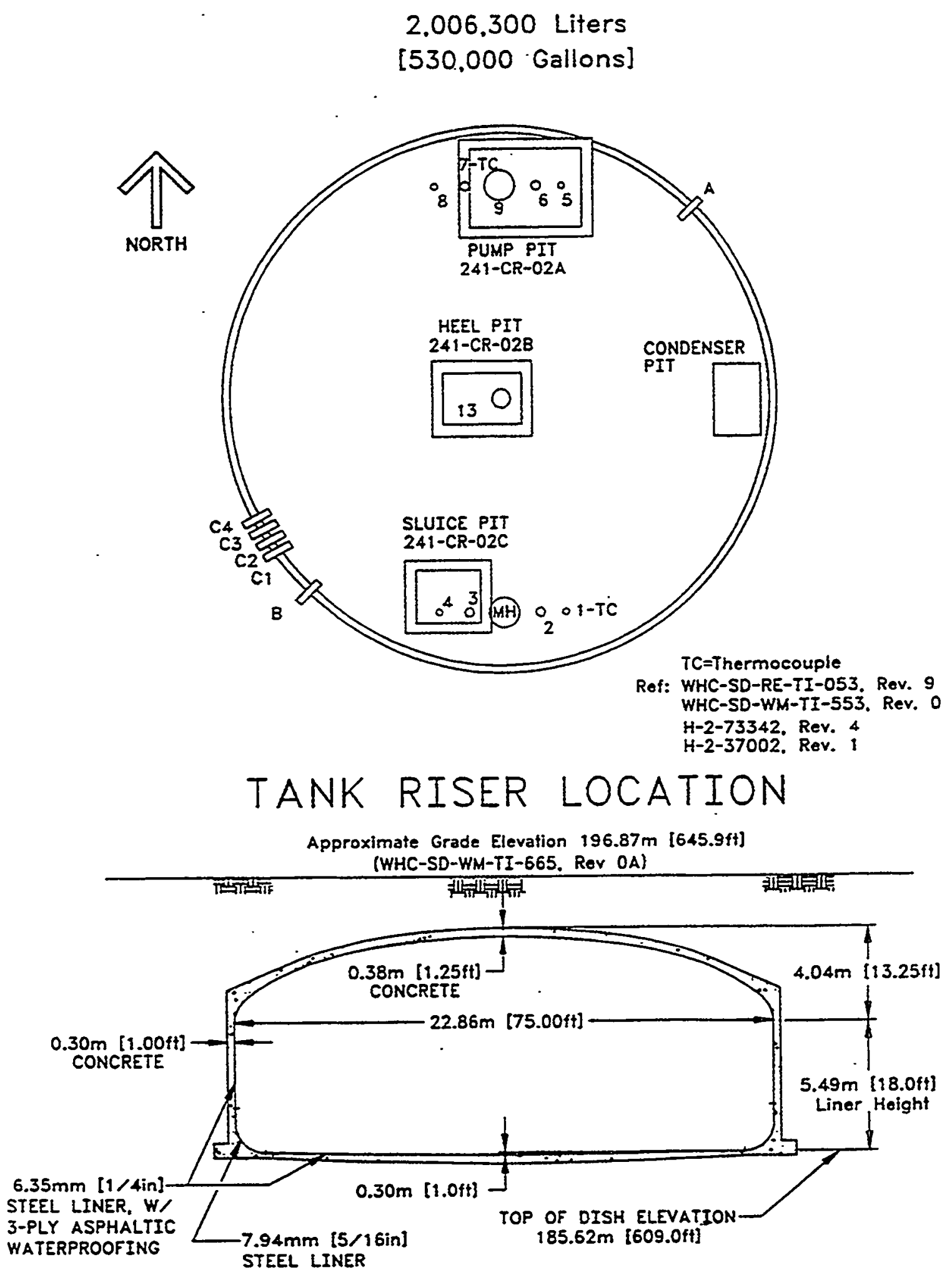

Figure 3.10 Tank 102-C riser locations 


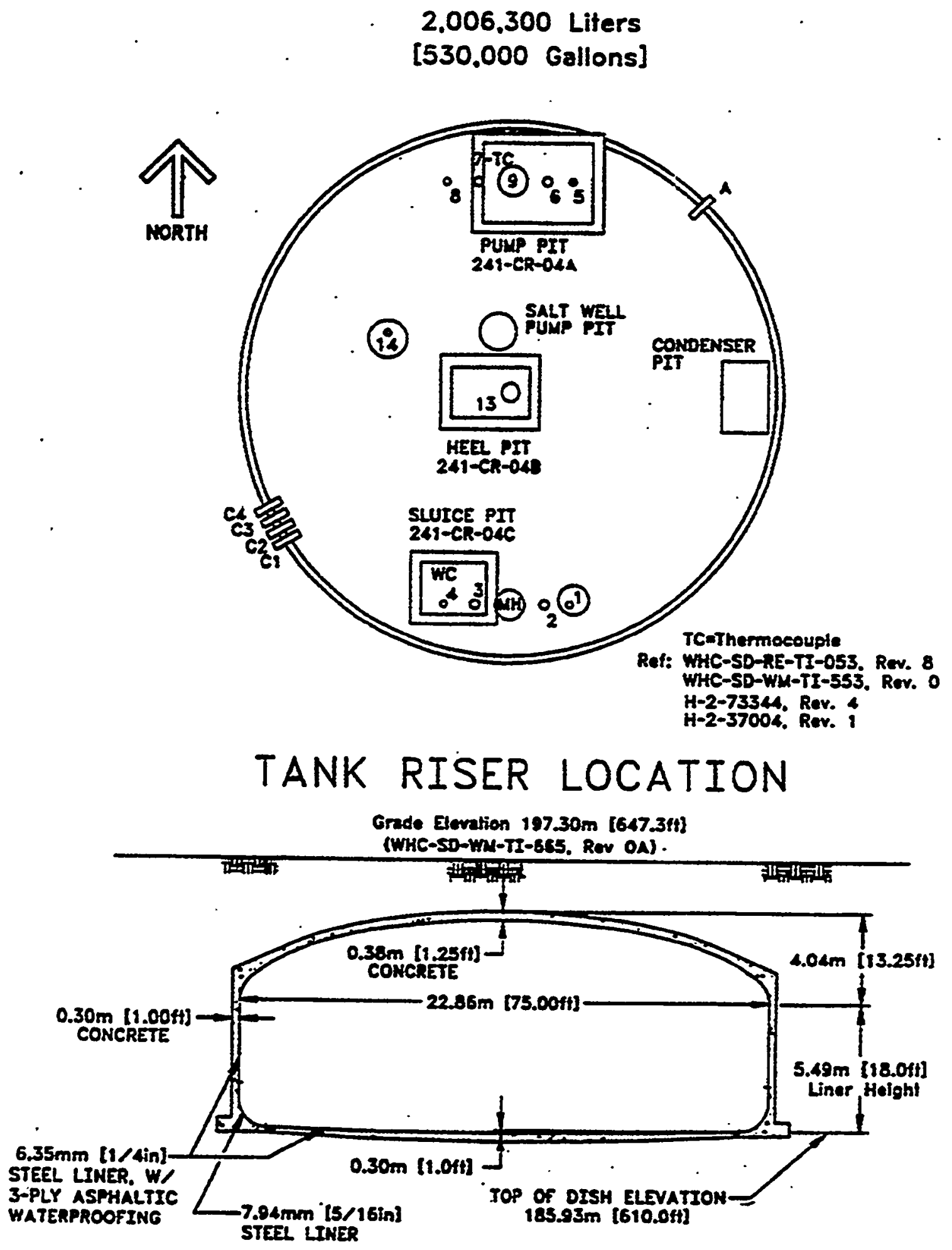

Figure 3.11 Tank 104-C riser locations 


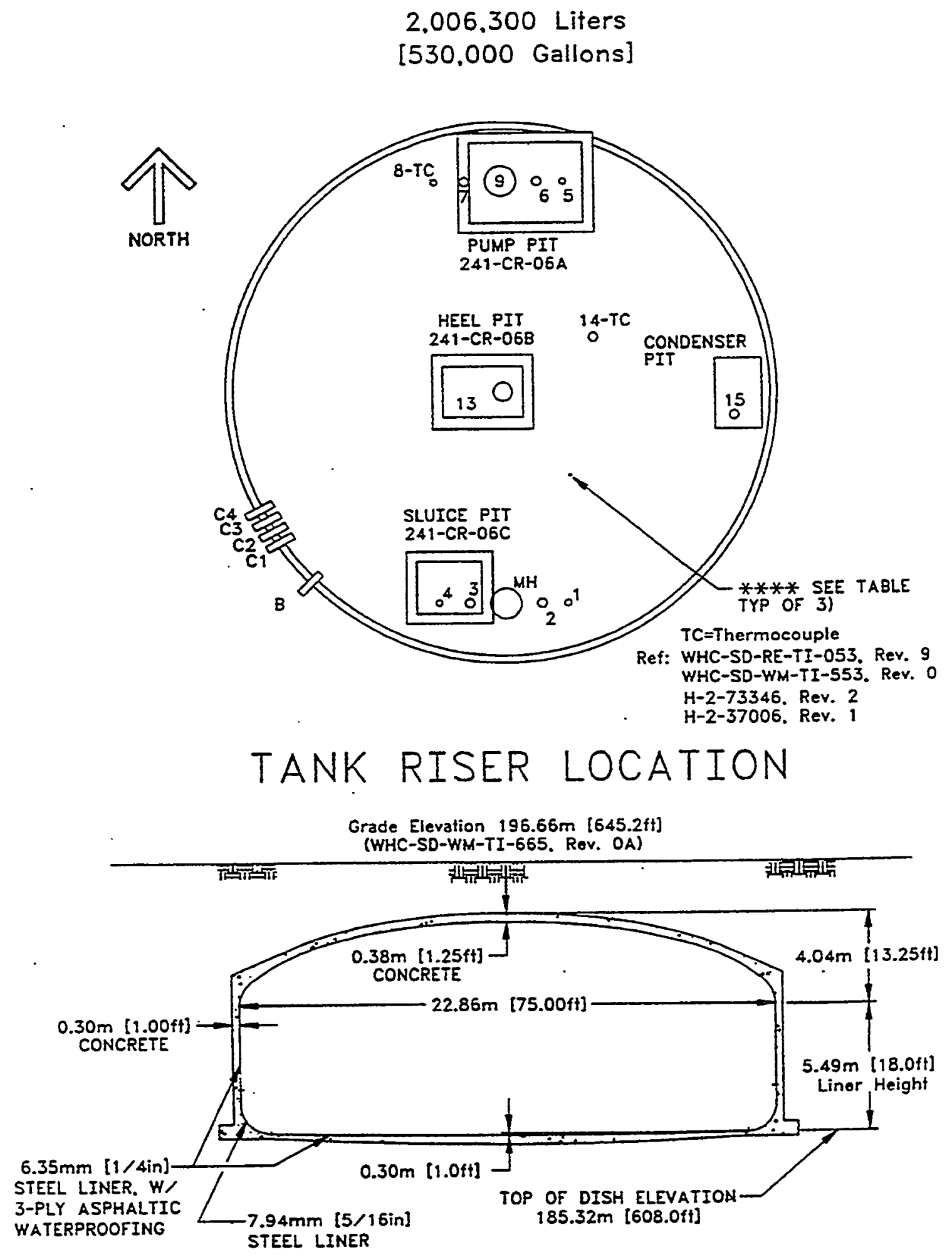

Figure 3.12 Tank 106-C riser locations 


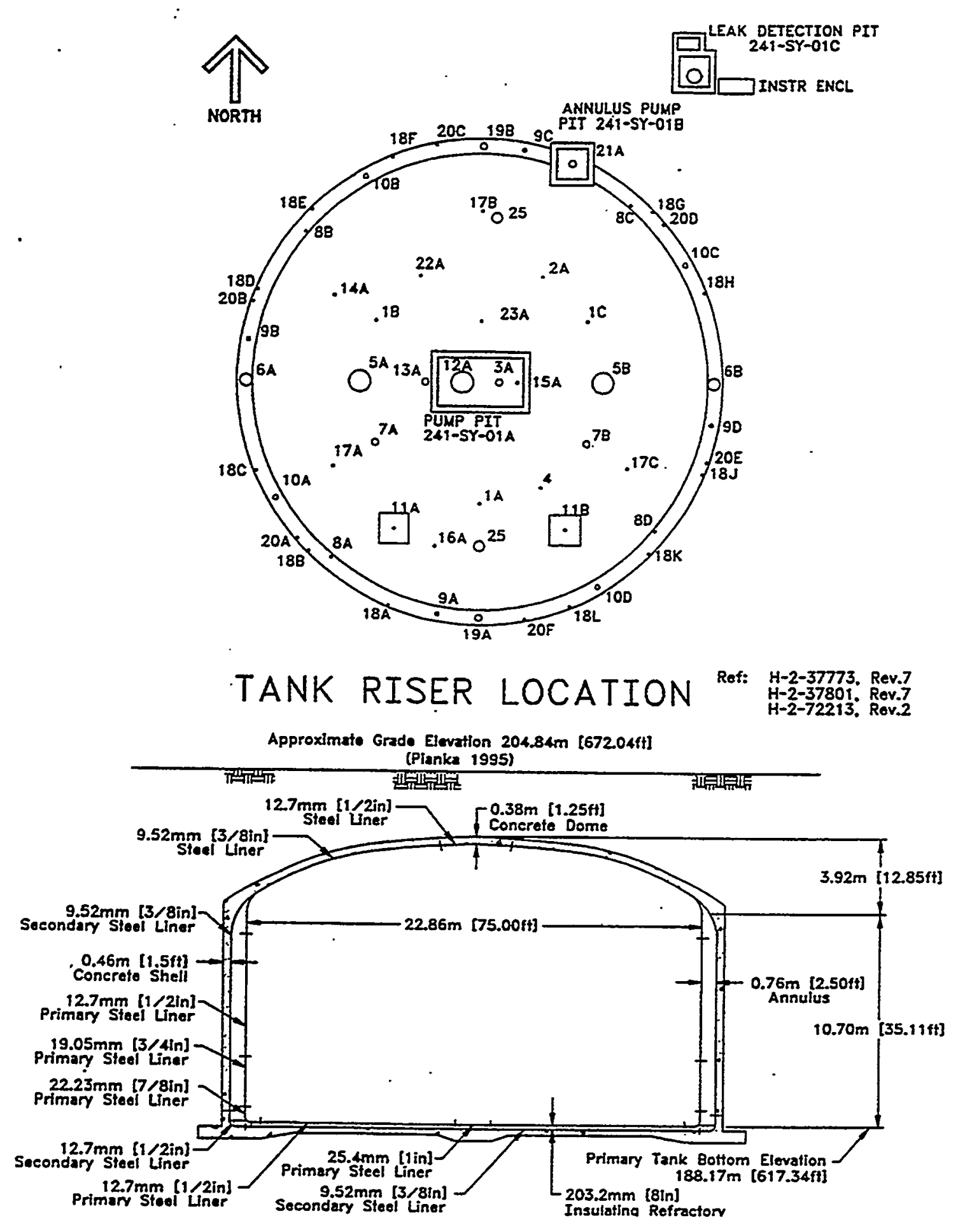

Figure 3.13 Tank 101-SY riser locations 


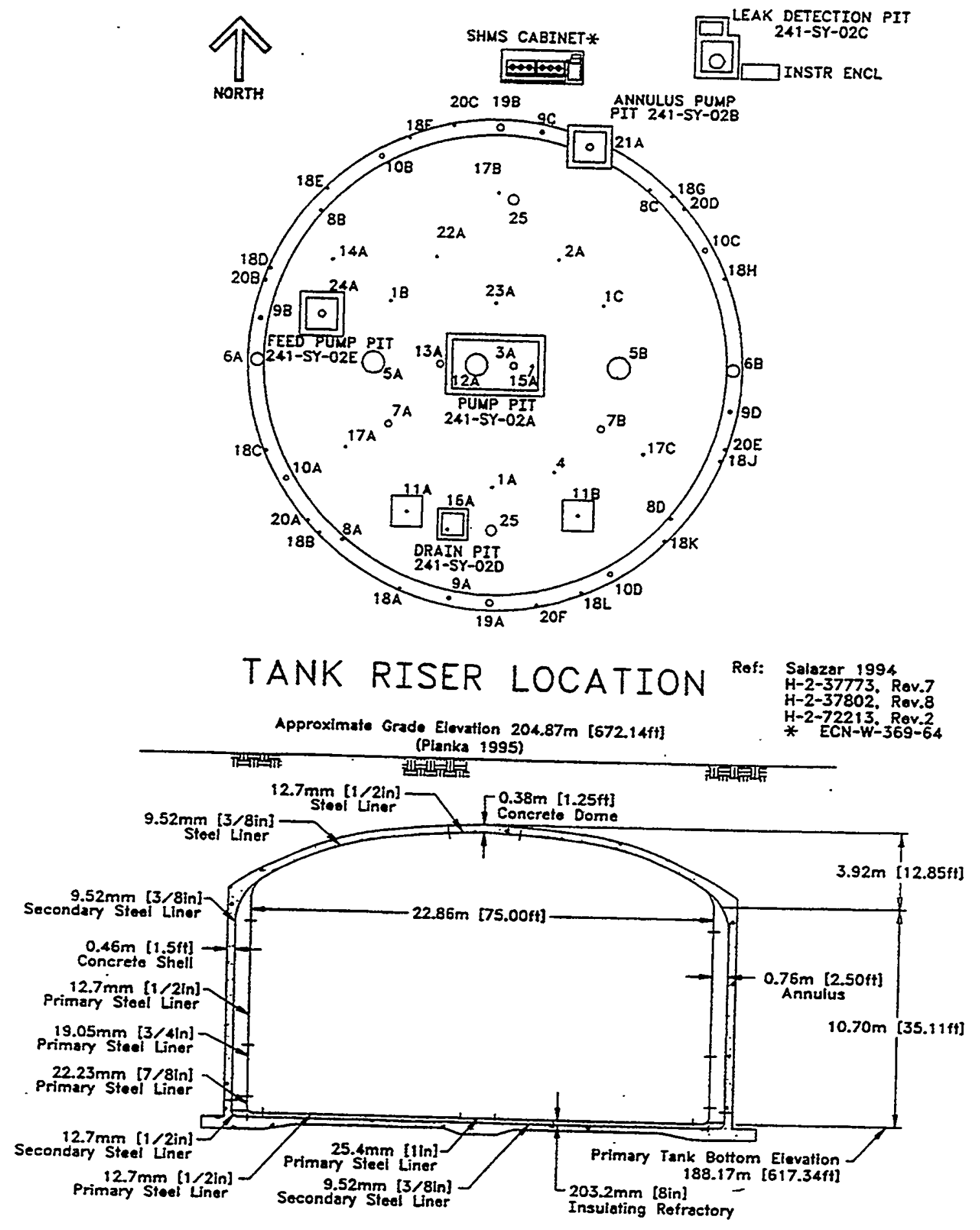

Figure 3.14 Tank 102-SY riser locations 


\subsection{Retrieval Scenarios}

The retrieval sequences are a function of waste type. The retrieval of water from the majority of the tanks involves supernatant and soluble solids, such as found in Tank 105-AN. Four tanks, 101- and 102$\mathrm{AY}$ and 101- and 102-AZ, contain insoluble solids. These tanks provide the additional challenge of being able to suspend, mobilize, and retrieve particulate.

\subsubsection{Retrieval of Waste from Tank 105-AN}

The assumed 105-AN retrieval scenario includes two planned transfers to retrieve supernatant and soluble solids.

Transfer 1 includes the following steps: degas the tank using mixer pumps, allow solids to settle, add water [up to $25.4 \mathrm{~cm}$ (10 in.)] to the tank to soften the crust (so that it will slump with the liquid level as the tank is emptied), decant the supernate to Tanks 104-AP or 102-AP using diluent at the transfer pump impeller (if required).

Transfer 2 includes: add diluent to the remaining waste in 105-AN, mix to dissolve the soluble solids, let the insoluble solids settle, and decant the new supernate to the 102- and 104-AP tanks, leaving the insoluble solids in 105-AN.

\subsubsection{Retrieval of Waste from the AY and AZ Tanks}

Four 112-kW (150-hp) mixer pumps will be installed to mix contents of Tank 102-AY in small batches for transfer to the vitrification plant. Tank 102-AY contains 22 airlift circulators as well as steam coils. This hardware provides a cluttered target for mixer pump operation. Insoluble solids will be accumulated in Tank 102-AY during retrieval of waste from Tanks 102-, 104-, and 106-C. After the retrieval of waste from those tanks is completed, mixer pumps will be installed in Tank 102-AY, and the insoluble solids will be slurried, retrieved, and transported as HLW feed.

\subsubsection{Retrieval System Configurations}

The major components of the retrieval systems include mixer pumps, transfer pumps, instrumentation, and ventilation. The system configurations proposed for these tanks can be compared in the diagrams that follow in Figures 3.15 through 3.23. 


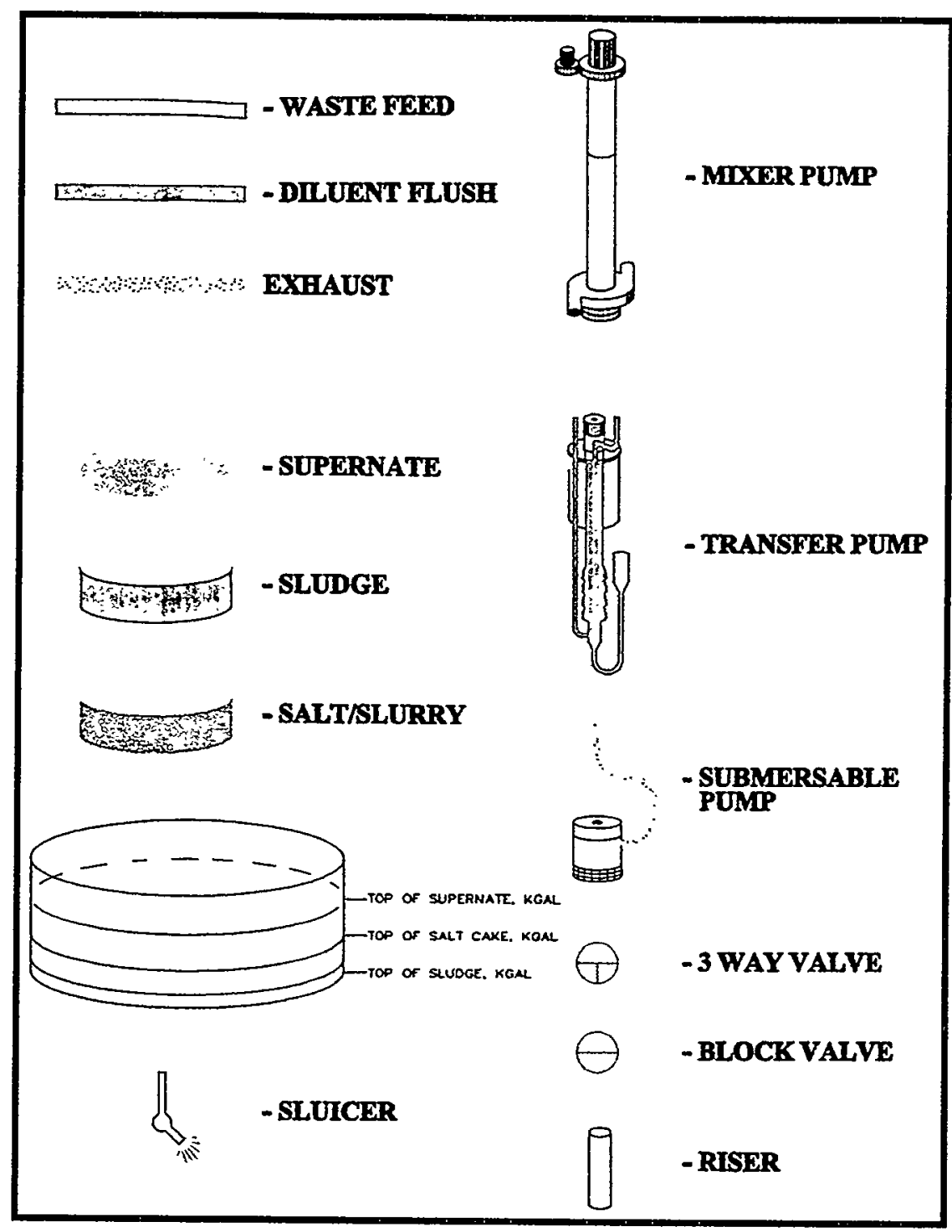

Figure 3.15 Legend for waste retrieval concepts
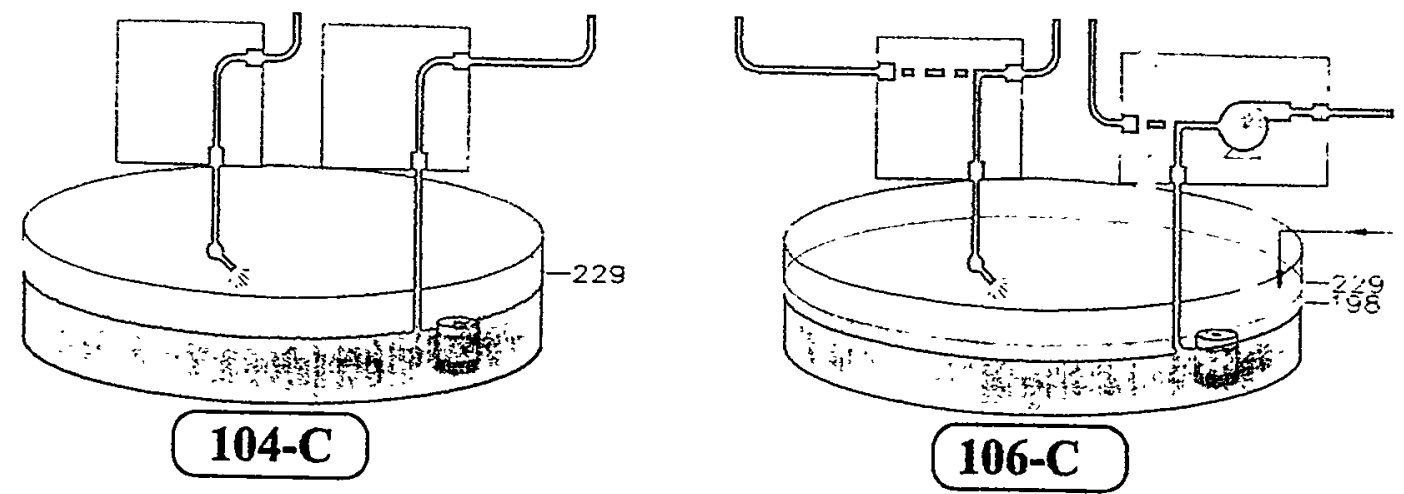

Figure 3.16 $\mathrm{C}$ tank waste retrieval approach 

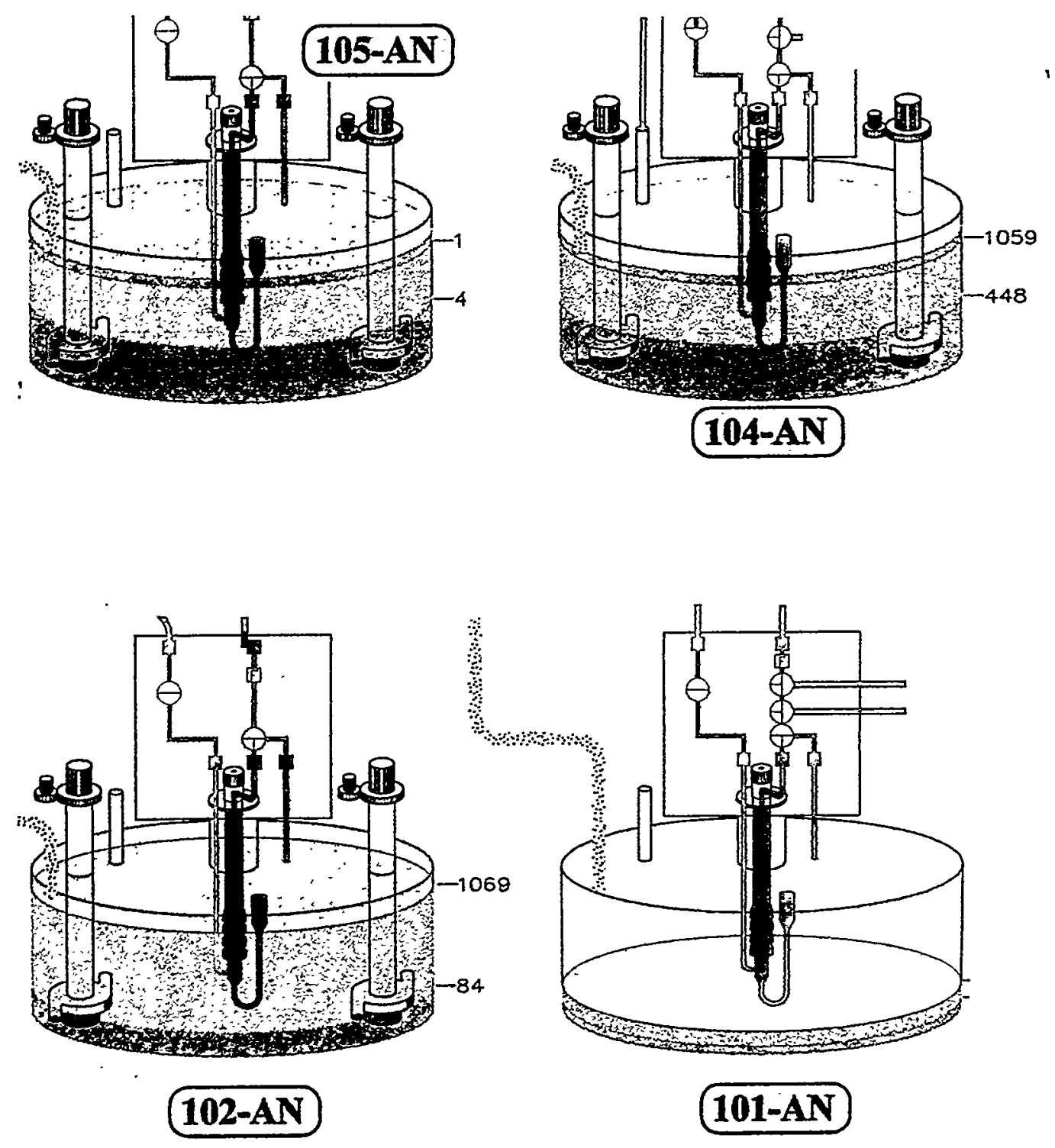

Figure 3.17 AN tank waste retrieval configuration 


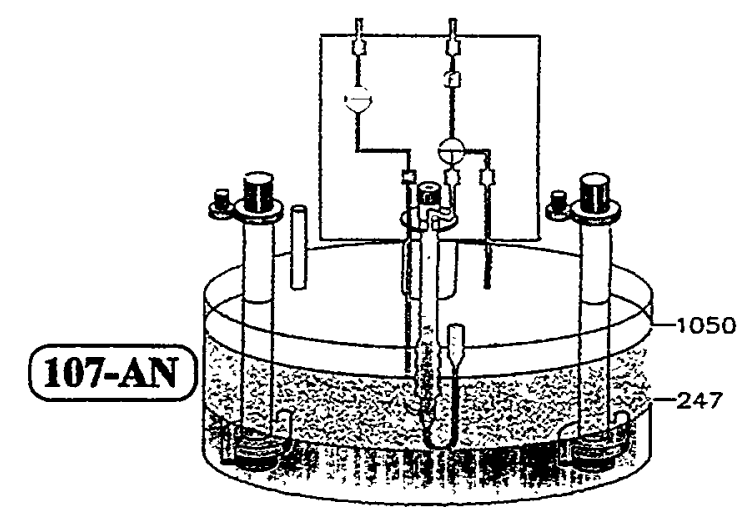

3
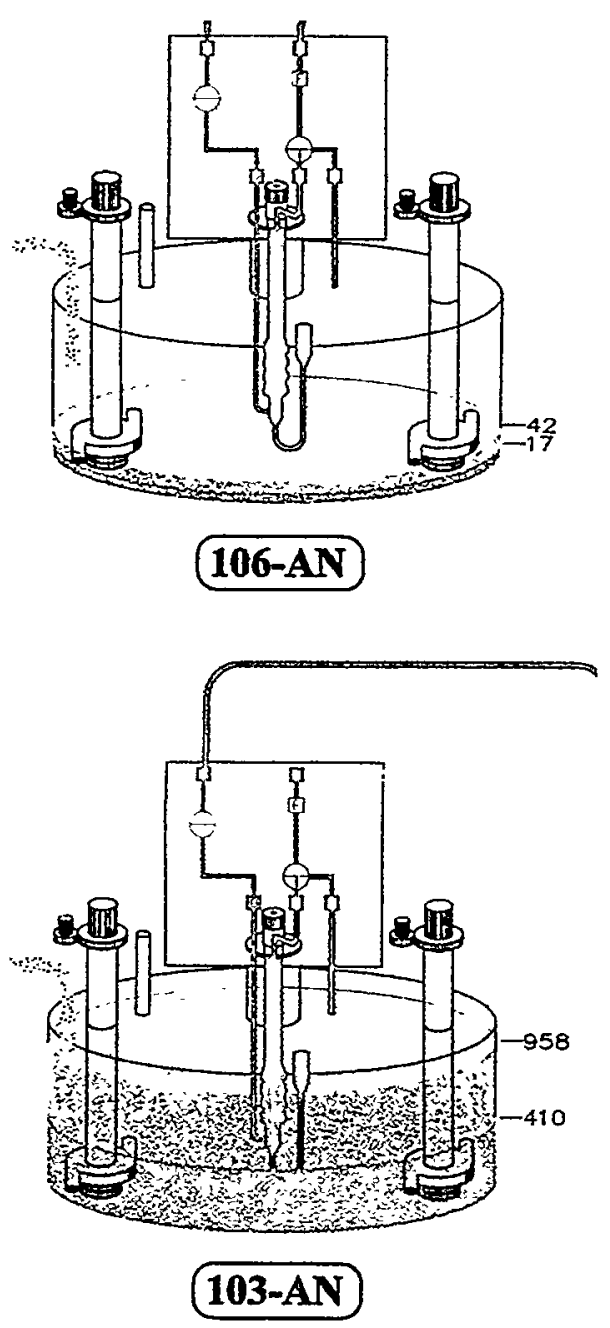

Figure 3.18 AN tank waste retrieval configuration 


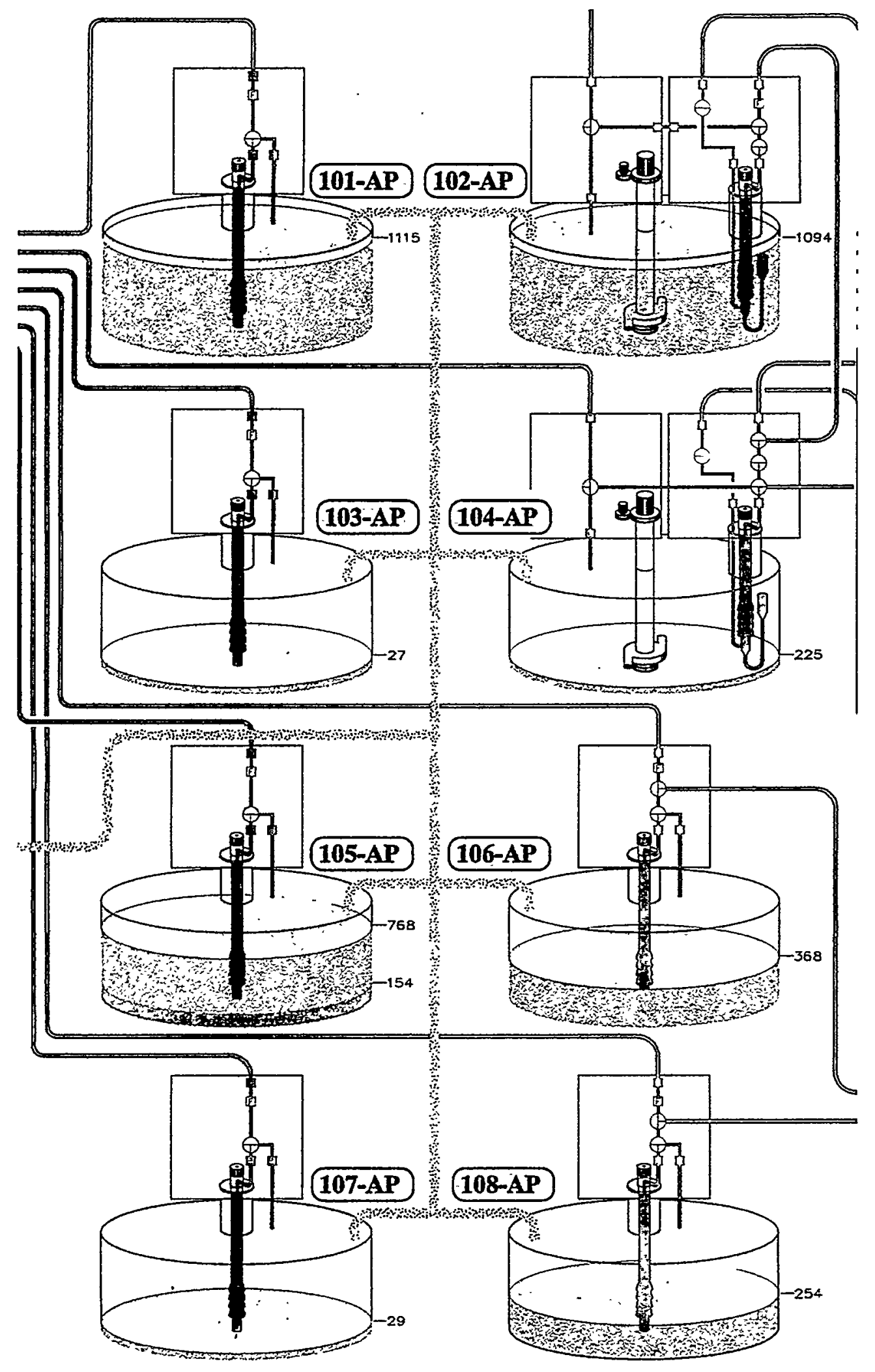

Figure 3.19 AP tank waste retrieval configuration 

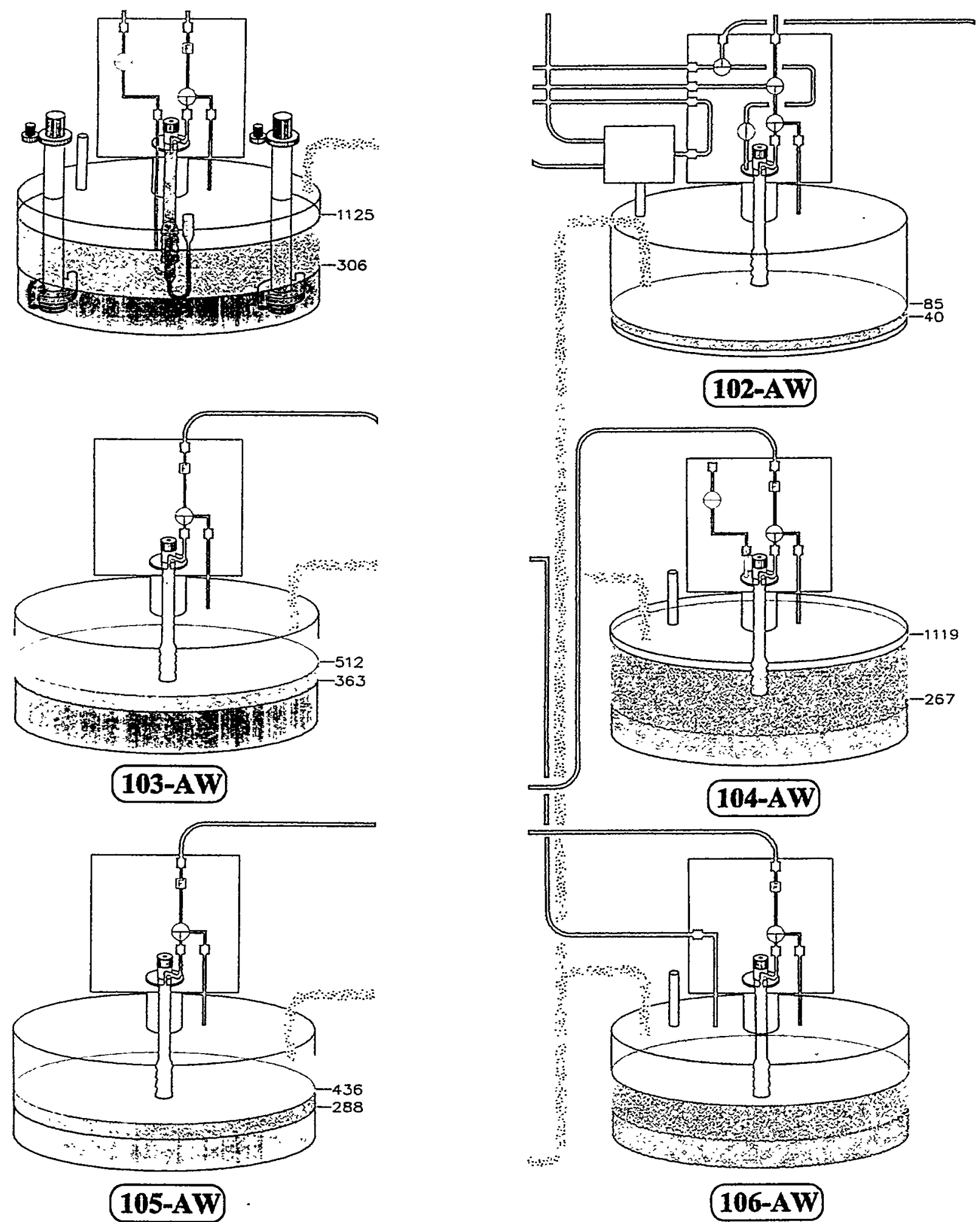

Figure 3.20 AW tank waste retrieval configuration 


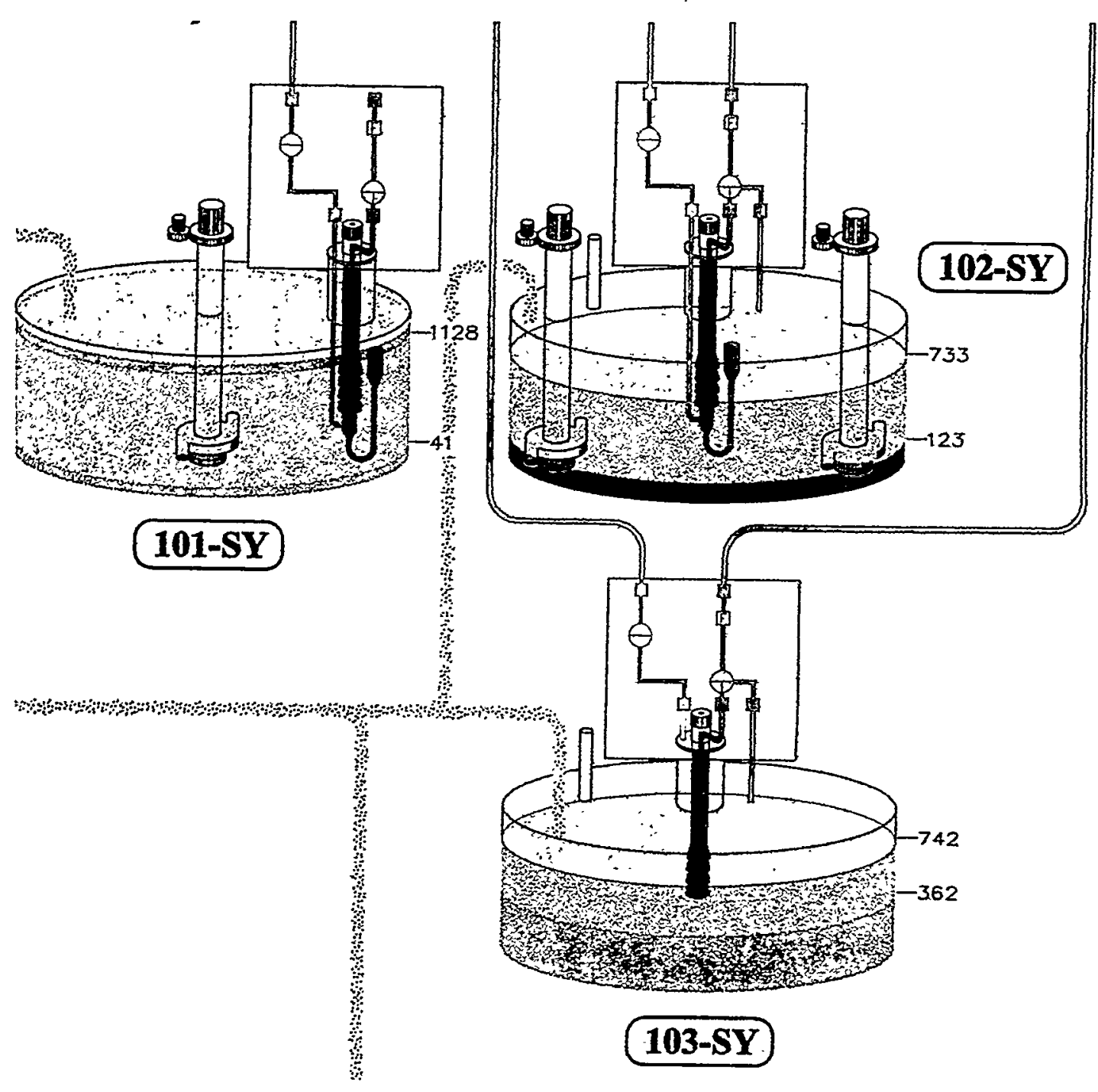

Figure 3.21 SY tank waste retrieval configuration 


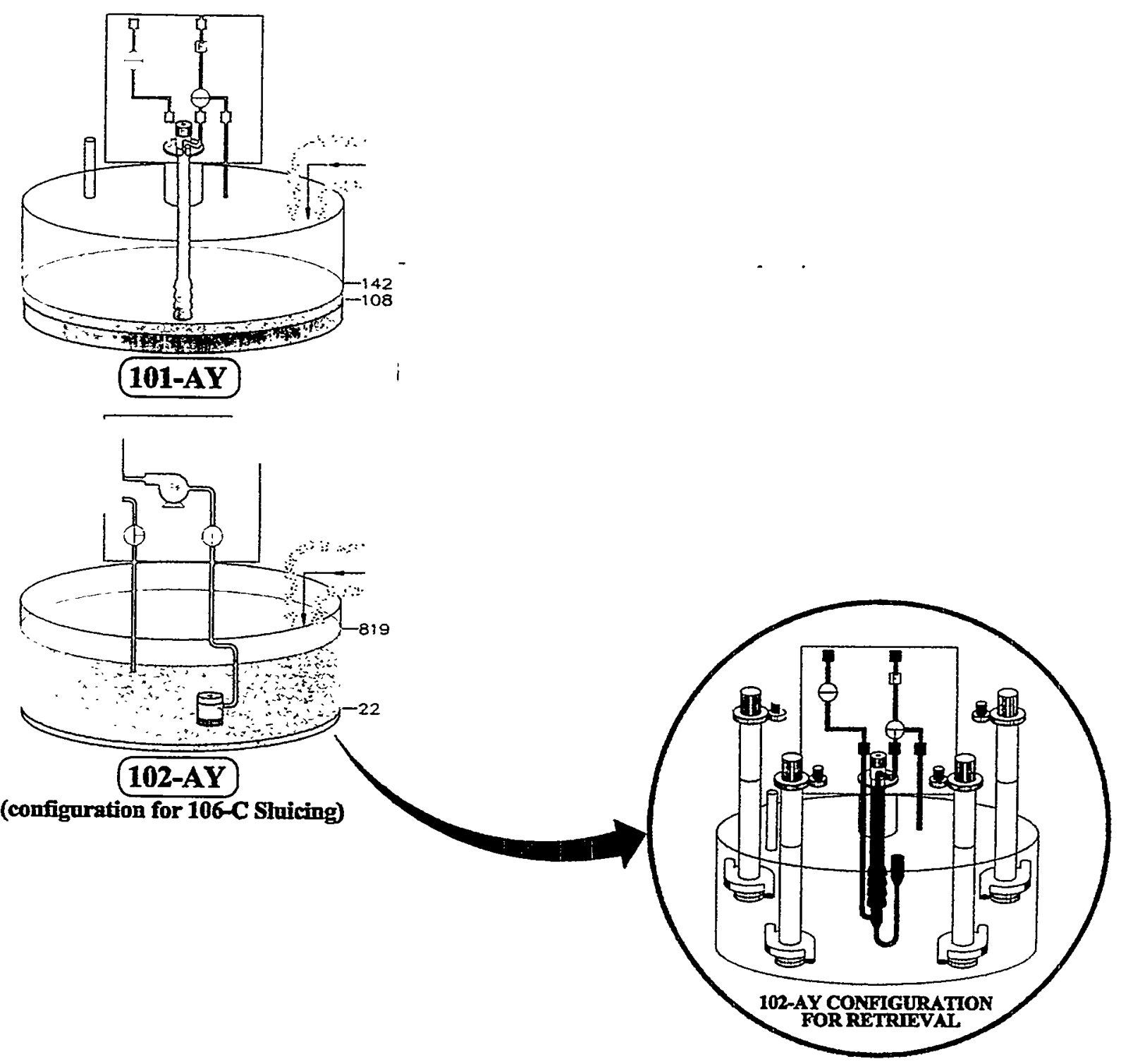

Figure 3.22 Waste retrieval configuration for AY tanks before and after C tank sluicing 


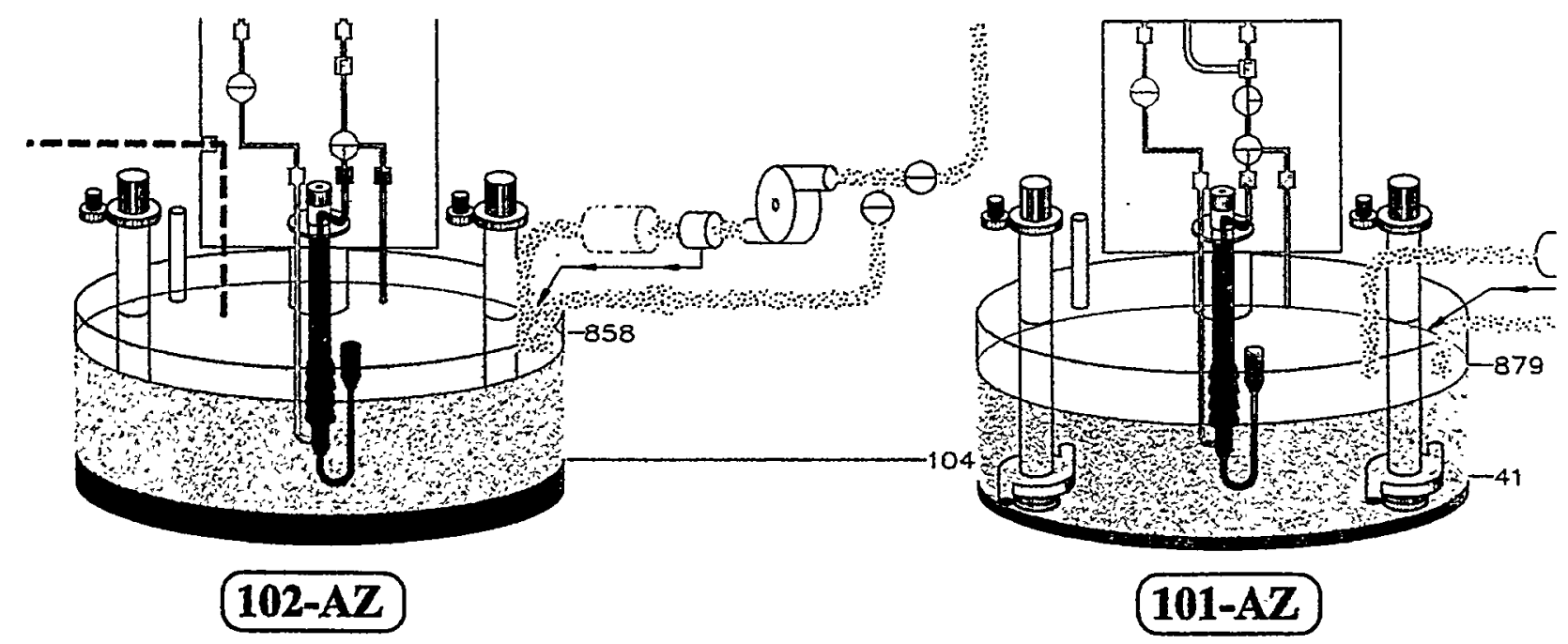

Figure 3.23 AZ tank waste retrieval configuration 


\section{Selection Guidance for Devices to Enhance Sludge Removal}

The following guidance was provided by staff at Numatec Hanford Company ${ }^{1}$ and Cogema Engineering Corp. ${ }^{2}$ to define the requirements for enhanced sludge removal. The document was issued February 23, 1999. ${ }^{3}$ Since that document was issued, staff at Plant Engineering and Retrieval Engineering, River Protection Project have updated and published that report (Tedeschi 2000). The derived requirements from that report are listed in Section 4.8. In the analysis that follows in Sections 5 through 8, notes are made to reflect the updated information presented in Tedeschi (2000) Section 4.8.

\subsection{Introduction}

Submerged jet rotating mixer pumps, in conjunction with transfer pumps, are the baseline method of retrieving waste for feed delivery to vitrification at Hanford. Considerable testing with simulants and computer modeling predicts this baseline method will mobilize and retrieve waste from double-shell tanks; however, the percent of waste removed by this submerged jet method is only an estimate because the effectiveness of submerged jets is directly tied to the in-situ shear strength and viscosity of the settled waste. Knowledge of settled waste in-situ shear strength and viscosity is poorly characterized and constrains the confidence limits of predictions from testing and modeling.

Testing of submerged jet retrieval with simulants in scale-model tanks shows some areas are outside the effective cleaning radius (ECR) of the jet (as shown in Figure 4.1) and not mobilized. If enough waste is trapped in these areas, the ability to meet waste feed delivery (WFD) commitments may be in jeopardy.

To increase confidence in meeting the required WFD schedules, a means to mobilize and retrieve these "dead" areas is needed. The amount of waste that will remain in these areas will not be known until retrieval from specific tanks has progressed substantially. In addition, the composition of waste in the dead area is unknown. Is the waste 1) outside the ECR and simply needs mobilization, 2) deposited in the area like snow in a drift, or 3 ) both?

The mission of the enhanced sludge retrieval device is to enhance removal of waste from double-shell tanks for the purpose of meeting WFD schedules, not to empty the tanks for closure. With this mission in mind, the effectiveness of the device and its life-cycle-cost must be compared against the option of going to another tank as a source of waste to meet the delivery schedule. This cost comparison between the device's life-cycle-cost and choosing an alternate tank is beyond the scope of this document because the information to complete this analysis does not yet exist.

\footnotetext{
${ }^{1}$ Richland, Washington.

${ }^{2}$ Richland, Washington.

${ }^{3}$ Shaw, CP. 1999. Subcontract Number 80232764-9-K001 Deliverable of Technical Task Plan Number RL09WT52 Waste Mixing Mobilization. LHMC-99-51209, COGEMA Engineering, Richland, Washington.
} 


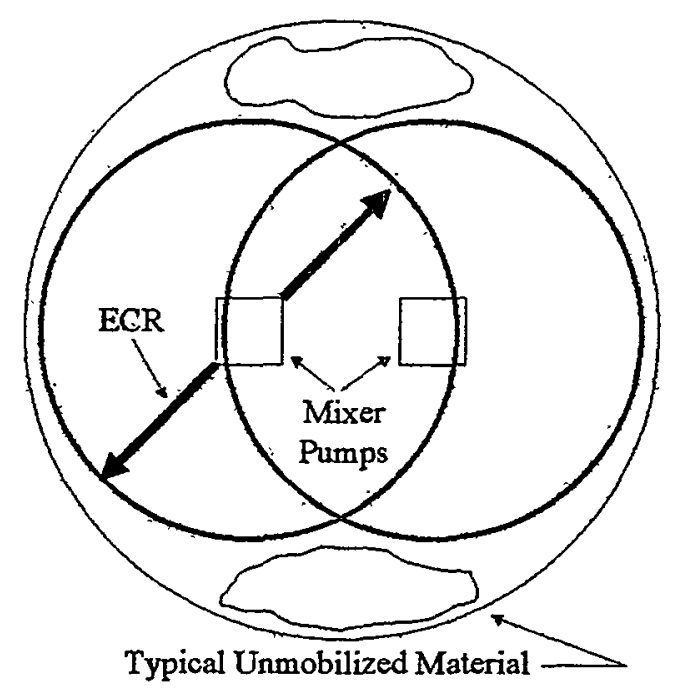

Figure 4.1 Example of mixer pump effective cleaning radius (ECR)

This selection guidance document is not intended to be a detailed analysis of functions and requirements, but rather a broad overview for initial screening criteria of commercial devices to enhance sludge removal. Before a device could be deployed in a radioactive waste tank, a detailed safety analysis would be required, installation decontamination and removal hardware built, and a considerable number of documents generated for the Operational Readiness Review process. Detailed discussion of this additional analysis, hardware, and documentation is premature and beyond the scope of this document.

\subsection{Functions}

This section defines what the device shall accomplish.

4.2.1 The device shall assist waste mobilization in the dead areas within the HLW tanks such that the waste can be removed via the existing transfer pump and, if needed, the operating mixer pump system.

4.2.2 The device shall detect, locate and measure accumulation of residual sludge.

\subsection{Requirements}

This section defines how well the device must perform.its function. (Tank 102-AZ used as base).

4.3.1 The device shall enhance mobilization for a radius of $3.0 \mathrm{~m}(10 \mathrm{ft})$ in waste with a shear strength of $1.96 \mathrm{kPa}\left(41 \mathrm{lbf} / \mathrm{ft}^{2}\right)$.

4.3.2 The device shall locate waste accumulated in the dead area within $+/-0.3 \mathrm{~m}(1 \mathrm{ft})$ vertically. 
4.3.3 The device shall be deployable from the tank bottom up to $3 \mathrm{~m}(10 \mathrm{ft}$ ) above the tank bottom.

4.3.4 The device shall pass though a 15.2-cm- (6-in.-) diameter riser. A 15.2-cm- (6-in.-) diameter riser may not be $15.2-\mathrm{cm}(6-\mathrm{in}$.) $\mathrm{ID}$ (inner diameter) in all cases, therefore, a device OD (outer diameter) of $12.7 \mathrm{~cm}$ ( $5 \mathrm{in}$.) maximum is recommended).

\subsection{Interfaces}

4.4.1 The device shall occupy preexisting available risers located over the dead areas.

4.4.2 The distance from the supporting surface (ground level) to the bottom of the tank is approximately $1.52 \mathrm{~m}(55 \mathrm{ft})$.

4.4.3 The device, and its support equipment, shall provide any special utilities; 480 volt, three-phase power and raw water are reasonably accessible.

4.4.4 The device shall be designed for the natural environmental conditions specified in Conrads (1998) Natural Phenomena Hazards Hanford Site, Washington.

4.4.5 Materials of construction shall be compatible with waste chemistry as specified in Kirkbride (1999) Tank Waste Remediation Operation and Utilization Plan and radiation as specified in Claghorn (1998) Estimated Dose to In-Tank Equipment.

\subsection{Constraints}

This section is a synopsis of the major constraining requirements imposed by WSRC-RP-94-346, Rev 3, June 1997 "Basis for Interim Operation (BIO) for Liquid Radioactive Waste Handling Facilities" and HINF-SD-WM-BIO-001 Rev 0, "Tank Waste Remediation System Bases for Interim Operation". The requirements in these documents will be used as the basis for the review to permit installation and operation of the device in a waste tank.

4.5.1 The device shall maintain tank confinement.

4.5.2 The device shall meet NFPA Class 1, Div. 1, Group B if in a flammable gas tank. Dielectric materials and static discharge must be considered.

4.5.3 The device shall not overload the tank's ventilation and confinement system. 0.142 standard $\mathrm{m}^{3} / \mathrm{s}$ ( $300 \mathrm{scfm}$ ) per tank is the average ventilation flow, selecting devices using more than $0.047 \mathrm{standard} \mathrm{m}^{3} / \mathrm{s}$ (100 scfm) will require close examination because other retrieval activities in the tank are challenging the system capacity). 
4.5.4 The device shall not exceed heat input limits of the tank. For reference, the baseline mixer pumps are two $224 \mathrm{~kW}(300-\mathrm{hp})$ units; 5 days of operating these pumps would raise the temperature of a 3785 $\mathrm{m}^{3}$ (million-gal) tank to near the BIO (basis for interim operation) limit. Potential additional tank cooling needs are being studied. As a target use $22.4 \mathrm{~kW}(30 \mathrm{hp})$ as an energy input limit for the proposed device.

4.5.5 The device shall not exceed dome-loading limits during installation, operation, or removal. This constraint goes beyond the simple weight of the device and must consider dropping the device during installation or removal and take into account any lateral loads the device may couple into the dome. Lateral loads may be either self induced, or induced by a mixer pump or earthquake. The device does not have to remain operable during these loads, but must not damage the tank and must be removable after the loading event. [For reference, mixer pumps weigh about $11340 \mathrm{~kg}(25,000 \mathrm{lbm})]$.

4.5.6 The device shall provide shielding for workers on the top of the tank.

4.5.7 Liquid addition, while allowable, is limited by space available and will be largely determined by prior partial retrieval.

\subsection{Operational Needs}

Operational needs include maintenance, ease of operation, removal and disposal. These requirements simplify operation and are practical considerations in the installation, operation, and removal of hardware.

4.6.1 Hardware features needing maintenance and calibration should be located remotely out of radiation areas.

4.6.2 Rotating seals should be located in the riser or tank, and a drain back to the tank shall be provided.

4.6.3 If possible, active items needing maintenance should not be located in the waste or riser.

4.6.4 The device shall be internally flushable, free draining, with no crud traps, cracks, or crevices.

4.6.5 The device shall have guide fins to prevent snagging during insertion or removal.

4.6.6 The device's internal voids, if not flushable or drainable, should be filled with foam.

4.6.7 The device's wetted surfaces should be stainless steel with a surface finish $125 \mathrm{rms}$ or better. 


\subsection{Assumptions}

The requirements include the following additional assumptions.

4.7.1 Radiation effects on materials understood by screeners. 1000 rads per hour is a conservative assumption.

4.7.2 $93.3 \mathrm{C}(200 \mathrm{~F})$ is the upper bound of waste temperature.

4.7.3 Waste is caustic $\mathrm{pH}>12$.

4.7.4 Soluble LLW tanks will not need sludge removal enhancement.

4.7.5 The tank will have an operating camera system.

\subsection{Updated Derived Requirements}

The updated derived requirements listed in Table 4.1 encompass greater scope than those described in Sections 4.1 through 4.7. References specific to these requirements are listed at the end of the table.

Table 4.1 Updated derived requirements for auxiliary solids mobilization

\begin{tabular}{|c|c|c|c|}
\hline $\begin{array}{l}\text { Function or } \\
\text { Requirement }\end{array}$ & $\begin{array}{c}\text { Value/Specification } \\
\text { Range } \\
\end{array}$ & Basis & Reference \\
\hline \multicolumn{4}{|c|}{ Process Specifications - Waste Properties } \\
\hline $\begin{array}{l}\text { Effective } \\
\text { cleaning radius }\end{array}$ & $\begin{array}{l}3 \mathrm{~m} \text { to } 6 \mathrm{~m}(9.8 \mathrm{ft} \text { to } 19.8 \\
\mathrm{ft}) \\
\text { Minimum performance } \\
\text { criteria }=3 \mathrm{~m}\end{array}$ & $\begin{array}{l}\text { The lower value represents a typical } \\
\text { distance from } 10.2 \mathrm{~cm}(4 \mathrm{in}) / 15.2(6 \\
\text { in.) risers to the interior tank } \\
\text { sidewall. Available } 1.1 \mathrm{~m} \mathrm{(} 42 \mathrm{in} \text {.) } \\
\text { risers are approximately } 6 \mathrm{~m} \text { from } \\
\text { the sidewall. }\end{array}$ & H-14-010507 Sheet 1 \\
\hline $\begin{array}{l}\text { Total waste } \\
\text { volume (includes } \\
\text { saltcake and } \\
\text { supernate) }\end{array}$ & $\begin{array}{l}579 \mathrm{Kl}(153 \mathrm{Kgal}) \text { to } \\
4,232 \mathrm{Kl}(1118 \mathrm{Kgal})\end{array}$ & $\begin{array}{l}\text { The range of reported total waste } \\
\text { volume for the included tanks. }\end{array}$ & (Hanlon 1999) \\
\hline $\begin{array}{l}\text { Sludge shear } \\
\text { strength }\end{array}$ & $\begin{array}{l}1.96 \mathrm{kPa}(19,631 \\
\left.\text { dynes } / \mathrm{cm}^{2}, 41 \mathrm{lbf} / \mathrm{ft}^{2}\right) \text { to } \\
4.8 \mathrm{kPa}(47,900 \\
\left.\text { dynes } / \mathrm{cm}^{2}, 100 \mathrm{lbf} / \mathrm{ft}^{2}\right) \\
\text { Minimum performance } \\
\text { criteria }=3.38 \mathrm{kPa}(33,800 \\
\left.\text { dyne } / \mathrm{cm}^{2}, 71 \mathrm{lbf} / \mathrm{ft}^{2}\right)\end{array}$ & $\begin{array}{l}\text { The lower value is commonly } \\
\text { reported data from past AZ-102 } \\
\text { analyses. The higher value } \\
\text { represents the highest limit reported } \\
\text { in the Tank Waste Remediation } \\
\text { System Operation and Utilization } \\
\text { Plan. }\end{array}$ & $\begin{array}{l}\text { (Kirkbride 1999a), } \\
\text { (Shaw, 1999) }\end{array}$ \\
\hline
\end{tabular}




\begin{tabular}{|c|c|c|c|}
\hline $\begin{array}{l}\text { Function or } \\
\text { Requirement }\end{array}$ & $\begin{array}{c}\text { Value/Specification } \\
\text { Range } \\
\end{array}$ & Basis & Reference \\
\hline Sludge volume & $\begin{array}{l}269 \mathrm{Kl}(71 \mathrm{Kgal}) \text { to } 1196 \\
\mathrm{Kl}(316 \mathrm{Kgal})\end{array}$ & $\begin{array}{l}\text { The lower value is the reported } \\
\text { volume in 214-SY-102. The higher } \\
\text { value is the reported volume for } \\
\text { AW-103. The highest value also } \\
\text { represents the largest reported sludge } \\
\text { volume for the included tanks. } \\
\text { While several of the noted tanks } \\
\text { have no sludge, SY-102 data was } \\
\text { used for lower data because it was a } \\
\text { highlighted tank for auxiliary } \\
\text { mixing. (Obviously } 0 \text { sludge would } \\
\text { be a the maximum low end, but not } \\
\text { practical for this scope.) }\end{array}$ & (Hanlon 1999) \\
\hline $\begin{array}{l}\text { Sludge bulk } \\
\text { density }\end{array}$ & $\begin{array}{l}1000 \text { to } 2000 \mathrm{~kg} / \mathrm{m}^{3} \text { (1 to } 2 \\
\mathrm{gm} / \mathrm{ml})\end{array}$ & $\begin{array}{l}\text { Core sample results of bottom sludge } \\
\text { layers for AW-103 (\#194) and SY- } \\
102 \text { (\#213) (TWINS database) }\end{array}$ & \\
\hline Sludge viscosity & $\begin{array}{l}0.06 \text { to } 10,000 \mathrm{~N}-\mathrm{s} / \mathrm{m}^{2}(0.6 \\
\text { to } 1.0 \mathrm{E}+05 \text { poise })\end{array}$ & $\begin{array}{l}\text { Solids viscosity for } A Z-101 \text { and } \\
\text { other reported slurry viscosities } \\
\text { range from } 0.05 \text { to } 0.1 \mathrm{~N}-\mathrm{s} / \mathrm{m}^{2}(0.5 \text { to } \\
1.0 \text { poise; Other reported data for } \\
\text { solids are noted at } 10 \mathrm{~N}-\mathrm{s} / \mathrm{m}^{2}(10,000 \\
\text { cP). The referenced } \mathrm{PNNL} \text { report is } \\
\text { an internal letter report that } \\
\text { references other reporting data; } \\
\text { characterization data on sludge } \\
\text { viscosity is limited. }\end{array}$ & $\begin{array}{l}\text { (Antoniak 1996) }{ }^{1} \text {, and } \\
\text { (Kirkbride 1999a) }\end{array}$ \\
\hline $\begin{array}{l}\text { Weight percent } \\
\text { solids of in-tank } \\
\text { settled sludge }\end{array}$ & $30-60 \%$ & $\begin{array}{l}\text { From AW-103 core sampling data } \\
\text { extrapolated from reported percent } \\
\text { water values (TWINS database core } \\
\text { 194) }\end{array}$ & \\
\hline $\begin{array}{l}\text { Solids particle } \\
\text { size }\end{array}$ & 0.2 to $50 \mu \mathrm{m}$ & $\begin{array}{l}\text { Commonly reported data for sludges } \\
\text { - typical smaller sizes, which tend to } \\
\text { be highly cohesive; translates to high } \\
\text { yield stresses in both shear and } \\
\text { compressive modes }\end{array}$ & $\begin{array}{l}\text { (Kirkbride 1999a) } \\
\text { (Powell 1997) }\end{array}$ \\
\hline $\begin{array}{l}\text { Supernatant } \\
\text { volume/levels }\end{array}$ & $\begin{array}{l}0 \text { to } 329 \mathrm{Kl}(0 \text { to } 87 \mathrm{Kgal}) \\
0 \text { to } 7.4 \mathrm{~m}(293 \mathrm{in} .)\end{array}$ & $\begin{array}{l}\text { Assuming a nominal ratio of } 410 \\
\mathrm{~m}^{3} / \mathrm{m}(2750 \mathrm{gal} / \mathrm{in} \text {.) }\end{array}$ & (Hanlon 1999) \\
\hline
\end{tabular}

1 Antoniak, Z. I., K. P. Recknagle, Simulation of Tank 241-AZ-101 Mobilization Tests and TEMPEST Code Performance Evaluation, Letter Report RET-093096, September 30, 1996, Pacific Northwest National Laboratory, Richland, Washington. 


\begin{tabular}{|c|c|c|c|}
\hline $\begin{array}{l}\text { Function or } \\
\text { Requirement }\end{array}$ & $\begin{array}{l}\text { Value/Specification } \\
\text { Range }\end{array}$ & Basis & Reference \\
\hline $\begin{array}{l}\text { Supernatant } \\
\text { specific gravity }\end{array}$ & 1.0 to 1.2 & $\begin{array}{l}\text { Supernatant grab sample results } \\
\text { obtained from TWINS database }\end{array}$ & \\
\hline $\begin{array}{l}\text { Supernatant } \\
\text { viscosity }\end{array}$ & $\begin{array}{l}0.0003 \text { to } 0.003 \mathrm{~N}-\mathrm{s} / \mathrm{m}^{2} \\
(0.3 \text { to } 3.0 \mathrm{cP})\end{array}$ & $\begin{array}{l}\text { Reported values from tank data and } \\
\text { simulation runs }\end{array}$ & (Kirkbride 1999a) \\
\hline Waste $\mathrm{pH}$ & Caustic, 12 to +14 & $\begin{array}{l}\text { Commonly reported data; waste } \\
\text { streams are a variety of sodium and } \\
\text { other metallic salts }\end{array}$ & \\
\hline Radioactive dose & $\begin{array}{l}\text { Peak dose rate } 10 \text { to } 1100 \\
\text { R/hr } \\
\text { Total Integrated Dose } 3.6 \\
\text { E05 to } 9.5 \mathrm{E} 07 \mathrm{R}\end{array}$ & Reported ranges & (Claghorn 1998) \\
\hline $\begin{array}{l}\text { Waste } \\
\text { temperature }\end{array}$ & $\begin{array}{l}15.5 \text { to } 35 \mathrm{C}(60 \text { to } 95 \mathrm{~F}) \\
\text { for } \mathrm{AW}-103 \text { \& SY-102 } \\
15.5 \text { to } 87.8 \mathrm{C}(60 \text { to } 190 \\
\text { F) for remaining tanks }\end{array}$ & Reported ranges & $\begin{array}{l}\text { Surveillance } \\
\text { Monitoring (TMACs) } \\
\text { for AW-103 and SY- } \\
102 \text { and Temperature } \\
\text { profile data from } \\
\text { Characterization } \\
\text { database (Twins) }\end{array}$ \\
\hline \multicolumn{4}{|c|}{ Operational Configuration Boundaries } \\
\hline Discharge angle & $\begin{array}{l}\text { Adjustable angles in both } \\
\text { the vertical and horizontal } \\
\text { plane. Best operation } \\
\text { would allow adjustment } \\
\text { remotely without breaking } \\
\text { of confinement. }\end{array}$ & $\begin{array}{l}\text { Mixing may be adequate with a fixed } \\
\text { angle position directed at a single } \\
\text { dead zone or buildup area. Waste } \\
\text { performance and shear strengths may } \\
\text { require a variable angle to enhance } \\
\text { mixing and impacting of thicker } \\
\text { sludges. }\end{array}$ & $\begin{array}{l}\text { Operation/design team } \\
\text { request }\end{array}$ \\
\hline Mixer height & $\begin{array}{l}\text { Variable (ability to } \\
\text { mobilize waste on bottom } \\
\text { and at increments } 4.6 \text { to } \\
6.1 \mathrm{~m} \text { ( } 15 \text { to } 20 \mathrm{ft} \text { ) above } \\
\text { bottom tank elevation) }\end{array}$ & $\begin{array}{l}\text { Mixing may be adequate with a fixed } \\
\text { position unit set on tank floor } \\
\text { directed at a single dead zone or } \\
\text { buildup area. Waste properties, } \\
\text { specifically shear strengths, may } \\
\text { require a phased lowering of the } \\
\text { mixer to start movement of lower } \\
\text { density material before impacting on } \\
\text { thicker sludges. Also, mixer may } \\
\text { need to be elevated to mobilize } \\
\text { suspended solids in waste layers. }\end{array}$ & $\begin{array}{l}\text { Operation/design team } \\
\text { request }\end{array}$ \\
\hline
\end{tabular}




\begin{tabular}{|c|c|c|c|}
\hline $\begin{array}{l}\text { Function or } \\
\text { Requirement }\end{array}$ & $\begin{array}{c}\text { Value/Specification } \\
\text { Range }\end{array}$ & Basis & Reference \\
\hline \multicolumn{4}{|c|}{ Installation Constraints } \\
\hline $\begin{array}{l}\text { Riser installation } \\
\text { width for pump } \\
\text { and related } \\
\text { assembly/mast }\end{array}$ & $\begin{array}{l}\text { Available nominal riser } \\
\text { sizes: } 10.2 \mathrm{~cm}, 15.2 \mathrm{~cm} \text {, } \\
30.5 \mathrm{~cm} \text {, and } 1.1 \mathrm{~m}(4 \mathrm{in} . \\
6 \mathrm{in.}, 12 \mathrm{in} . \text {, and } 42 \mathrm{in} .)\end{array}$ & $\begin{array}{l}\text { Varied spare risers, and risers used } \\
\text { for operations that could be } \\
\text { accessed (e.g., construction ports, } \\
\text { defunct installed equipment, } \\
\text { camera ports etc.) }\end{array}$ & $\begin{array}{l}\text { H-2-64447 Rev } 7 \\
\text { H-14-010501 Sheet } 4 \\
\text { Rev } 2 \\
\text { H-14-010502 Sheet } 2 \\
\text { Rev } 1 \\
\text { H-14-010502 Sheet } 4 \\
\text { Rev } 1 \\
\text { H-14-010507 Sheet } 1 \\
\text { Rev 0 } \\
\text { H-14-010507 Sheet } 2 \\
\text { Rev 0 } \\
\text { H-14-010531 Sheet } 2 \\
\text { Rev 2 }\end{array}$ \\
\hline $\begin{array}{l}\text { Utilities } \\
\text { availability }\end{array}$ & $\begin{array}{l}240 / 480 \text { VAC } \\
\text { Flush water through tanker } \\
\text { or existing piping } \\
\text { No instrument or } \\
\text { compressed air }\end{array}$ & $\begin{array}{l}\text { Current tank farm configurations; } \\
\text { systems requiring compressed air } \\
\text { or continual flushing will need to } \\
\text { install auxiliary provisions }\end{array}$ & N/A \\
\hline $\begin{array}{l}\text { Natural } \\
\text { phenomena } \\
\text { design }\end{array}$ & None & $\begin{array}{l}\text { Final Safety Analysis } \\
\text { Report/Technical Safety } \\
\text { Requirements, however dependent } \\
\text { upon final design }\end{array}$ & (LMHC 1999a) \\
\hline $\begin{array}{l}\text { Ventilation } \\
\text { system impacts }\end{array}$ & $\begin{array}{l}<0.24 \text { standard } \mathrm{m}^{3} / \mathrm{s}(50 \\
\mathrm{scfm}) \text { additional load }\end{array}$ & $\begin{array}{l}\text { Conservative design estimate with } \\
\text { existing ventilation systems }\end{array}$ & Estimate \\
\hline $\begin{array}{l}\text { Delivered } \\
\text { horizontal } \\
\text { displacement on } \\
\text { vertical } \\
\text { protuberances } \\
\text { (e.g., } \\
\text { thermocouple } \\
\text { probes) in } \\
\text { cleaning radius }\end{array}$ & $\begin{array}{l}\text { Maximum } 2.54 \mathrm{~cm}(1 \text { in. }) \\
\text { at tank bottom elevation }\end{array}$ & $\begin{array}{l}\text { Calculations for specific tanks and } \\
\text { waste protuberances will need to } \\
\text { be made on a case-by-case basis. } \\
\text { The reported range value is } \\
\text { derived from calculation in } \mathrm{AZ} \text { - } \\
101 \text { but represents a conservative } \\
\text { target for further evaluation }\end{array}$ & (Julyk 1997) \\
\hline $\begin{array}{l}\text { Material of } \\
\text { construction }\end{array}$ & $\begin{array}{l}\text { Wetted materials shall } \\
\text { maintain 5-year life } \\
\text { expectancy within waste } \\
\text { conditions; minimum } 304 \\
\text { stainless steel on all } \\
\text { wetted parts }\end{array}$ & $\begin{array}{l}5 \text { years estimated maximum life } \\
\text { for staging tank application }\end{array}$ & Estimate \\
\hline
\end{tabular}




\begin{tabular}{|c|c|c|c|}
\hline $\begin{array}{l}\text { Function or } \\
\text { Requirement }\end{array}$ & $\begin{array}{c}\text { Value/Specification } \\
\text { Range } \\
\end{array}$ & Basis & Reference \\
\hline Pit confinement & $\begin{array}{l}\text { Installation on potential } \\
\text { risers within pits shall not } \\
\text { intrude upon piping, and } \\
\text { shall allow for } \\
\text { reinstallation of all } \\
\text { existing pit covers. }\end{array}$ & $\begin{array}{l}\text { Minimization of operational and } \\
\text { project impact }\end{array}$ & $\begin{array}{l}\text { Operation cost } \\
\text { effectiveness }\end{array}$ \\
\hline \multicolumn{4}{|c|}{ Safety Requirements } \\
\hline Lift criteria & $\begin{array}{l}\text { Installation/removal will } \\
\text { be per critical lift } \\
\text { requirements of Hanford } \\
\text { Hoisting \& Rigging } \\
\text { Manual }\end{array}$ & $\begin{array}{l}\text { Final Safety Analysis } \\
\text { Report/Technical Safety } \\
\text { Requirement dome loading controls }\end{array}$ & $\begin{array}{l}\text { (LMHC 1999a) } \\
\text { AC } 5.16\end{array}$ \\
\hline $\begin{array}{l}\text { Electrical systems } \\
\text { within tank vapor } \\
\text { space, and pits }\end{array}$ & $\begin{array}{l}\text { Meets NFPA Class 1, Div } \\
1 \text {, Group B; design criteria } \\
\text { shall be reviewed by } \\
\text { independent buyer expert } \\
\text { group }\end{array}$ & $\begin{array}{l}\text { Final Safety Analysis } \\
\text { Report/Technical Safety } \\
\text { Requirement ignition controls }\end{array}$ & $\begin{array}{l}\text { (LMHC 1999a) } \\
\text { AC } 5.10\end{array}$ \\
\hline $\begin{array}{l}\text { Electrical systems } \\
\text { within submerged } \\
\text { waste streams }\end{array}$ & $\begin{array}{l}\text { Meets NFPA Class 1, Div } \\
1, \text { Group B or be } \\
\text { demonstrated by process } \\
\text { that submerged system } \\
\text { provides no spark to tank } \\
\text { vapor space }\end{array}$ & $\begin{array}{l}\text { Final Safety Analysis } \\
\text { Report/Technical Safety } \\
\text { Requirement ignition controls }\end{array}$ & $\begin{array}{l}\text { (LMHC 1999a) } \\
\text { AC } 5.10\end{array}$ \\
\hline Weight & $\begin{array}{l}\text { Free supporting mast and } \\
\text { pump assembly must meet } \\
\text { allowable limits in } \\
\text { addition to mixer pumps } \\
\text { and retrieval pumps OR } \\
\text { may be designed to rest on } \\
\text { tank bottom, fully } \\
\text { supported by floor }\end{array}$ & $\begin{array}{l}\text { Final Safety Analysis } \\
\text { Report/Technical Safety } \\
\text { Requiremient Dome Loading } \\
\text { Controls; value will need specific } \\
\text { calculation however generic rule is } \\
\text { that riser may support } 45,359 \mathrm{~kg} \text { ( } 50 \\
\text { ton) load limit }\end{array}$ & $\begin{array}{l}\text { (LMHC 1999a) } \\
\text { AC } 5.16\end{array}$ \\
\hline Control system & $\begin{array}{l}\text { Capable of being } \\
\text { interlocked or remotely } \\
\text { shut down upon indication } \\
\text { of high waste temperature } \\
\text { or tank ventilation } \\
\text { shutdown }\end{array}$ & $\begin{array}{l}\text { Final Safety Analysis } \\
\text { Report/Technical Safety } \\
\text { Requirement waste temperature and } \\
\text { ventilation controls }\end{array}$ & $\begin{array}{l}\text { (LMHC 1999a) } \\
\text { LCOs 3.2.1, 3.2.2, } \\
3.2 .3,3.3 .1 \text {, and 3.3.2 }\end{array}$ \\
\hline
\end{tabular}




\begin{tabular}{|c|c|c|c|}
\hline $\begin{array}{l}\text { Function or } \\
\text { Requirement }\end{array}$ & $\begin{array}{c}\text { Value/Specification } \\
\text { Range } \\
\end{array}$ & Basis & Reference \\
\hline Heat input & $\begin{array}{l}\text { Maximum sludge/waste } \\
\text { temperature rise of } 5.6 \mathrm{C} \\
(10 \mathrm{~F}) \text { during continuous } \\
\text { equipment operation and } \\
\text { following } 12 \text { hours }\end{array}$ & $\begin{array}{l}\text { Final Safety Analysis } \\
\text { Report/Technical Safety } \\
\text { Requirement waste temperature } \\
\text { controls, estimated conservative } \\
\text { value based upon safety } \\
\text { requirements; target motor energy } \\
\text { output should be in the range of } 37 \\
\text { to } 75 \mathrm{~kW} \text { ( } 50 \text { to } 100 \mathrm{hp)}\end{array}$ & $\begin{array}{l}\text { (LMHC 1999a) } \\
\text { and engineering } \\
\text { estimation }\end{array}$ \\
\hline \multicolumn{4}{|c|}{ Operation, Maintenance, \& Radiological Control Constraints } \\
\hline $\begin{array}{l}\text { Location of } \\
\text { control } \\
\text { mechanisms }\end{array}$ & $\begin{array}{l}\text { Localized control at tank } \\
\text { farm within tank farm } \\
\text { control room (greater than } \\
100 \mathrm{~m} \text { ( } 328 \mathrm{ft} \text { ) away from } \\
\text { tank) }\end{array}$ & ALARA, and Conduct of operations & None \\
\hline $\begin{array}{l}\text { Location of } \\
\text { electrical } \\
\text { components } \\
\text { requiring } \\
\text { calibration } \\
\end{array}$ & $\begin{array}{l}\text { Not located within pits or } \\
\text { shielded areas }\end{array}$ & $\begin{array}{l}\text { ALARA and conduct of operations } \\
\text { allowing routine access for } \\
\text { calibration without removing } \\
\text { shielding }\end{array}$ & None \\
\hline Riser seal & $\begin{array}{l}\text { Shall maintain existing } \\
\text { confinement; riser seal } \\
\text { shall be gasketed. } \\
\text { Rotating seals shall be } \\
\text { liquid sealed with drain } \\
\text { back to the tank }\end{array}$ & ALARA & None \\
\hline Decontamination & $\begin{array}{l}\text { Free draining, internal } \\
\text { flushable, with internal } \\
\text { void areas for material } \\
\text { trapping filled with } \\
\text { compatible solids (e.g., } \\
\text { foam) }\end{array}$ & $\begin{array}{l}\text { Conduct of operations; current } \\
\text { planning does not involve reuse of } \\
\text { mixer }\end{array}$ & None \\
\hline Shielding & $\begin{array}{l}\text { System shall be provide } \\
\text { with shielding for } \\
\text { protection of workers } \\
\text { during installation and } \\
\text { removal for disposal }\end{array}$ & $\begin{array}{l}\text { ALARA; current planning does not } \\
\text { involve reuse of mixer }\end{array}$ & None \\
\hline
\end{tabular}




\section{Evaluation of Enhanced Sludge Removal Technologies}

Several studies have been conducted to provide background and a decision analysis for mobilizing and retrieving sludge from double-shell tanks (Brothers et al. 1997, Powell et al. 1997). These studies focus on all of the double-shell tanks. Specific criteria are required to evaluate technologies for enhanced sludge removal.

Based on the selection guidance provided in Section 4, criteria for evaluation are developed in Section 5.1. These criteria are summarized in tabular form in Section 5.2. In Section 5.3, the criteria are applied to the technologies described in detail in Section 6.

\subsection{Criteria for Evaluation}

The selection guidance listed in Section 4.0 provides the framework to tailor a system for deployment in a Hanford tank to assist in waste mobilization. Some of these criteria are essential qualities that a device must possess to be considered for this application. Other criteria define parameters that could be modified during construction to ensure that the device mates with the existing tank infrastructure. Other criteria define qualities that can be added to an existing device to meet a specified function. The guidance is prioritized to permit evaluation of existing commercial equipment for applicability for providing a device to enhance sludge removal. In addition, changes noted in the Tedeschi (2000) that further define these criteria are noted in bold.

\subsubsection{Primary Requirements}

Primary requirements are those that must be met by the device in order to perform the desired task. Three items were identified.

- The device shall assist waste mobilization in dead areas.

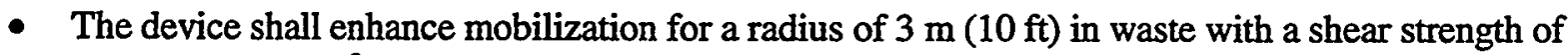
$1.96 \mathrm{kPa}\left(41 \mathrm{lbf} / \mathrm{ft}^{2}\right)$.

Note: Tedeschi (2000) defined the effective cleaning radius as $3 \mathrm{~m}$ to $6 \mathrm{~m}(9.8$ to $19.8 \mathrm{ft})$ and defined the minimum waste shear strength minimum performance criteria as $3.38 \mathrm{kPa}\left(71 \mathrm{lbf} / \mathrm{ft}^{2}\right)$

- To put the shear strength value in perspective, it is compared with simulants developed at Pacific Northwest National Laboratory to model waste properties (Powell et al. 1997, Bamberger et al. 1998). A 50\% kaolin, 13\% plaster, 37\% water simulant developed to model sludge had a shear strength of $2.5 \mathrm{kPa}\left(52 \mathrm{lbf} / \mathrm{ft}^{2}\right)$. A $22.5 \%$ kaolin, $40 \%$ plaster, $37.5 \%$ water simulant developed to

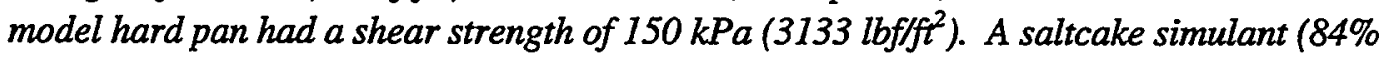
dynamate in water) had a compressive strength of $19 \mathrm{MPa}\left(396,825 \mathrm{lbf} / \mathrm{ft}^{2}\right)$. The shear strength 
of $1.96 \mathrm{kPa}\left(41 \mathrm{lb} / \mathrm{ft}^{2}\right)$ selected by Shaw and the minimum performance criteria shear strength of $3.38 \mathrm{kPa}\left(71 \mathrm{lb} / \mathrm{ft}^{2}\right)$ defined in Tedeschi (2000) are both very low.

- The device shall pass through a 12.7- to 15.2-cm- (5- to 6-in.-) diameter riser.

Note: Tedeschi (2000) defined available nominal riser diameters of $10.2,15.2,30.5 \mathrm{~cm}$ and 1.1 $\mathrm{m}(4,6,12$, and $42 \mathrm{in}$.)

\subsubsection{Secondary Requirements}

Secondary requirements include the ability to assess the condition of the waste in the tank. One item was identified.

- The device shall detect, locate, and measure accumulation of residual sludge.

4.3.2 The device shall locate waste accumulated in the dead area within $\pm 0.3 \mathrm{~m}(1 \mathrm{ft})$ vertically.

Assessing the location of waste in the tank could be addressed by using the tank operating camera system (identified as item 4.7.5) or by deploying specialized instrumentation as a part of, or in conjunction with, the enhanced removal device.

\subsubsection{Safety Requirements}

The device operation must not compromise the integrity of the tank. All of the items listed in Section 4.5 constraints fall into this category. Several of the items affect device operation and potentially performance.

4.5.2 The device shall meet NFPA Class 1, Div 1, Group B if in a flammable gas tank. Dielectric materials and static discharge must be considered.

4.5.3 The device shall not overload the tank's ventilation and confinement system. [0.142 standard $\mathrm{m}^{3} / \mathrm{s}(300 \mathrm{scfm})$ per tank is the average ventilation flow, selecting devices using more than $0.047 \mathrm{standard} \mathrm{m}^{3} / \mathrm{s}(100 \mathrm{scfm})$ will require close examination because other retrieval activities in the tank are challenging the system capacity].

Note: Tedeschi (2000) defines the ventilation system impact as $<0.023 \mathrm{standard} \mathrm{m}^{3} / \mathrm{s}(50$ scfm) additional load.

4.5.4 The device shall not exceed heat input limits of the tank. As a target, use $22.4 \mathrm{~kW}$ (30 hp) as an energy input limit for the proposed device.)

Note: Tedeschi (2000) defines the heat input as a maximum sludge/waste temperature rise of $5.6 \mathrm{C}(10 \mathrm{~F})$ during continuous equipment operation and following 12 hours.

4.5.5 The device shall not exceed dome loading limits during installation, operation, or removal. [For reference, mixer pumps weigh about $11,340 \mathrm{~kg}(25,000 \mathrm{lbm})$.

4.5.7 Liquid addition, while allowable, is limited by space available and will be largely determined by prior partial retrieval. 


\subsubsection{Design - Construction - Installation Details}

Many of the operational needs and materials of construction can be addressed after selection of the type of enhanced retrieval system during its design and construction for deployment in a specific tank riser or series of tank risers.

\subsection{Evaluation Matrix}

Based on the information presented above, two tables were constructed to permit comparison of the technologies. In Table 5.1, the sludge mobilization technologies are compared. In Table 5.2, the technologies are compared against the ranking criteria.

\subsection{Technology Evaluation}

The technologies described in Sections 6 and 7 have enough information regarding operation during testing for radioactive deployment or actual operation in a radioactive waste environment; therefore, they were selected for comparison to the deployment selection criteria. In Table 5.3, the technologies are compared with respect to the ability to mobilize sludge. In Table 5.4, the technologies are grouped into three categories: 1) meeting the ranking criteria, 2) the ability to be modified to meet the ranking criteria, and 3) not readily modified to meet the ranking criteria.

\subsection{Technology Summary}

Based on the acceptance criteria, one technology, the borehole-miner extendible-nozzle has the proven ability to meet key primary requirements. The borehole-miner extendible-nozzle can mobilize extremely hard waste at a distance of $3 \mathrm{~m}(10 \mathrm{ft})$. The arm extension of $3 \mathrm{~m}(10 \mathrm{ft})$, and its ability to move back and forth, can be used to sweep waste from collection piles deposited by the mixer pump back into the mixer pump path or toward the retrieval pump inlet. The current device mast is larger than the 15.2-cm- (6-in.-) diameter riser; however, this dimension could be modified for the application.

Two other technologies, the pulsating mixer pump and fluidic pulse-jet mixing will fit through a 15.2cm- (6-in.-) diameter riser, however, the technologies need to be evaluated to determine the effective cleaning radius of the technology and the range of shear strengths of sludge that they can dislodge. 
Table 5.1 Matrix for technology comparison

\begin{tabular}{||l|l||}
\hline Criteria & Technology \\
\hline Technique & Type of mobilization system \\
\hline Jet pressure & Provides jet pressure range and fluid \\
\hline Flow rate & Fluid flow rate per jet \\
\hline Enhances dissolution & Technology specific \\
\hline Mixes viscous liquids & Technology specific \\
\hline Mixes slurries & Technology specific \\
\hline Mobilizes settled solids & Technology specific \\
\hline Dislodges solid heels & Technology specific \\
\hline Power & Power required to produce jet \\
\hline $\begin{array}{l}\text { Adds heat to tank during } \\
\text { operation }\end{array}$ & Technology specific \\
\hline Operating limits & $\begin{array}{l}\text { Is system operation limited by the waste level in the tank or other } \\
\text { constraints? }\end{array}$ \\
\hline $\begin{array}{l}\text { Percent secondary waste } \\
\text { generated }\end{array}$ & Based on the amount of water the system adds to the tank \\
\hline Deployment & How is the system deployed? \\
\hline Remotely deployed & Yes or no. \\
\hline Maintainability & What parts need periodic maintenance and where are they located? \\
\hline Removal & How is the system removed from the tank? \\
\hline
\end{tabular}


Table 5.2 Criteria for technology selection

\begin{tabular}{|c|c|c|c|}
\hline Number and Criteria & $\begin{array}{l}\text { Technology Meets } \\
\text { The Criteria }\end{array}$ & $\begin{array}{l}\text { Technology Can Be } \\
\text { Modified To Meet } \\
\text { Criteria }\end{array}$ & $\begin{array}{l}\text { Technology Cannot } \\
\text { Readily Be Modified } \\
\text { To Meet Criteria }\end{array}$ \\
\hline \multicolumn{4}{|l|}{$\begin{array}{l}\text { 4.2.1 Assist waste } \\
\text { mobilization in dead areas }\end{array}$} \\
\hline \multicolumn{4}{|l|}{$\begin{array}{l}\text { 4.3.1 Enhance mobilization } \\
\text { for a radius of } 3 \mathrm{~m}(10 \mathrm{ft})\end{array}$} \\
\hline \multicolumn{4}{|l|}{$\begin{array}{l}\text { 4.3.1 Enhance mobilization } \\
\text { of } 1.96 \mathrm{kPa}\left(41 \mathrm{lbf} / \mathrm{ft}^{2}\right) \text { shear } \\
\text { strength sludge }\end{array}$} \\
\hline \multicolumn{4}{|l|}{$\begin{array}{l}\text { 4.3.4 Pass through } 15.2-\mathrm{cm}- \\
\text { (6-in.-) diameter riser }\end{array}$} \\
\hline \multicolumn{4}{|l|}{$\begin{array}{l}\text { 4.2.2 Detect, locate and } \\
\text { measure accumulation of } \\
\text { residual sludge }\end{array}$} \\
\hline \multicolumn{4}{|l|}{$\begin{array}{l}\text { 4.3.2 Locate waste } \\
\text { accumulated in a dead area } \\
\text { within } \pm 0.3 \mathrm{~m}(1 \mathrm{ft}) \\
\text { vertically }\end{array}$} \\
\hline \multicolumn{4}{|l|}{$\begin{array}{l}\text { 4.5.2 Meets NFPA Class 1, } \\
\text { Div 1, Group B for } \\
\text { flammable gas tank }\end{array}$} \\
\hline \multicolumn{4}{|l|}{$\begin{array}{l}\text { 4.5.3 Does not overload } \\
\text { tanks ventilation or } \\
\text { confinement system } \\
\text { [generates }<0.047 \text { standard } \\
\mathrm{m}^{3} / \mathrm{s}(100 \mathrm{scfm}) \text { aerosol] }\end{array}$} \\
\hline \multicolumn{4}{|l|}{$\begin{array}{l}\text { 4.5.4 Does not exceed tank } \\
\text { heat input }[22.4 \mathrm{~kW}(30 \mathrm{hp})]\end{array}$} \\
\hline \multicolumn{4}{|l|}{$\begin{array}{l}\text { 4.5.5 Does not exceed dome } \\
\text { loading limits }[<11340 \mathrm{~kg} \\
(25,000 \mathrm{lbm})]\end{array}$} \\
\hline 4.5.7 Limited liquid addition & & & \\
\hline
\end{tabular}


Table 5.3 Comparison of the waste mobilization technologies

\begin{tabular}{|c|c|c|c|c|c|c|c|c|c|}
\hline Criteria & Pulsed Air & $\begin{array}{c}\text { Pulsating } \\
\text { Mixer Pump }\end{array}$ & $\begin{array}{c}\text { Fluidic } \\
\text { Pulse-Jet } \\
\text { Mixing }\end{array}$ & $\begin{array}{l}\text { C-106 } \\
\text { Sluicer }\end{array}$ & $\begin{array}{l}\text { Borehole- } \\
\text { Miner } \\
\text { Extendible- } \\
\text { Nozzle }\end{array}$ & $\begin{array}{c}\text { Waste- } \\
\text { Retrieval } \\
\text { End Effector }\end{array}$ & $\begin{array}{c}\text { High- } \\
\text { Pressure } \\
\text { Scarifier }\end{array}$ & Flygt Mixer & $\begin{array}{l}\text { Mixer } \\
\text { Pump }\end{array}$ \\
\hline Technique & $\begin{array}{l}\text { compressed } \\
\text { air pulses }\end{array}$ & $\begin{array}{l}\text { compressed } \\
\text { air propels } \\
\text { slurry jet }\end{array}$ & $\begin{array}{l}\text { compressed } \\
\text { air propels } \\
\text { slurry jet }\end{array}$ & $\begin{array}{l}\text { water or fluid } \\
\text { jet }\end{array}$ & $\begin{array}{l}\text { water or fluid } \\
\text { jet }\end{array}$ & water jet & water jet & $\begin{array}{l}\text { propeller } \\
\text { creates a fluid } \\
\text { jet }\end{array}$ & $\begin{array}{l}\text { high-volume } \\
\text { oscillatory } \\
\text { fluid jets }\end{array}$ \\
\hline $\begin{array}{l}\text { Jet } \\
\text { pressure }\end{array}$ & $\begin{array}{l}0.35 \text { to } 0.69 \\
\mathrm{MPa}(5 \text { to } \\
100 \text { psi) air }\end{array}$ & $\begin{array}{l}0 \text { to } 0.69 \\
\mathrm{MPa}(0 \text { to } \\
100 \mathrm{psi})\end{array}$ & $\begin{array}{l}0 \text { to } 0.69 \\
\mathrm{MPa}(0 \text { to } \\
100 \mathrm{psi})\end{array}$ & $\begin{array}{l}\text { to } 2.07 \mathrm{MPa} \\
\text { (300 psi) }\end{array}$ & $\begin{array}{l}0 \text { to } 20.7 \\
\mathrm{MPa}(0 \text { to } \\
3000 \mathrm{psi})\end{array}$ & $\begin{array}{l}0 \text { to } 69 \text { or } 207 \\
\mathrm{MPa}(0 \text { to } \\
10,000 \text { or } \\
30,000 \mathrm{psi})\end{array}$ & $\begin{array}{l}379 \mathrm{MPa} \\
(55,000 \\
\text { psi) }\end{array}$ & & $\begin{array}{l}\text { up to } 2.8 \\
\mathrm{MPa}(400 \\
\text { psi )liquid }\end{array}$ \\
\hline Flow rate & $\begin{array}{l}0.005 \\
\text { standard } \\
\mathrm{m}^{3} / \mathrm{s}(10 \\
\mathrm{scfm}) \text { air } \\
\text { per plate }\end{array}$ & tbd & tbd & $\begin{array}{l}0.022 \mathrm{~m}^{3} / \mathrm{s} \\
(350 \mathrm{gal} / \mathrm{min})\end{array}$ & $\begin{array}{l}0 \text { to } 0.0095 \\
\mathrm{~m}^{3} / \mathrm{s}(0 \text { to } \\
150 \mathrm{gal} / \mathrm{min})\end{array}$ & $\begin{array}{l}0.0063 \mathrm{~m}^{3} / \mathrm{s} \\
(10 \mathrm{gal} / \mathrm{min}) \\
\text { /jet }\end{array}$ & $\begin{array}{l}0.00038 \\
\mathrm{~m}^{3} / \mathrm{s}(6 \\
\mathrm{gal} / \mathrm{min}) \\
/ \mathrm{jet}\end{array}$ & $\begin{array}{l}1.1 \mathrm{~m}^{3} / \mathrm{s} \\
(17,500 \\
\mathrm{gal} / \mathrm{min})\end{array}$ & $\begin{array}{l}\text { up to } 0.315 \\
\mathrm{~m}^{3} / \mathrm{s}(5000 \\
\mathrm{gal} / \mathrm{min}) / \mathrm{jet}\end{array}$ \\
\hline $\begin{array}{l}\text { Enhances } \\
\text { dissolution }\end{array}$ & tbd & yes & yes & yes & yes & yes & yes & yes & yes \\
\hline $\begin{array}{l}\text { Mixes } \\
\text { viscous } \\
\text { liquids } \\
\end{array}$ & yes & yes & yes & yes & yes & yes & yes & yes & yes \\
\hline $\begin{array}{l}\text { Mixes } \\
\text { slurries }\end{array}$ & yes & yes & yes & yes & yes & yes & yes & yes & yes \\
\hline $\begin{array}{l}\text { Mobilizes } \\
\text { settled } \\
\text { solids }\end{array}$ & $\begin{array}{l}\text { to some } \\
\text { extent }\end{array}$ & $\begin{array}{l}\text { to some } \\
\text { extent }\end{array}$ & $\begin{array}{l}\text { to some } \\
\text { extent }\end{array}$ & $\begin{array}{l}\text { to some } \\
\text { extent }\end{array}$ & yes & yes & yes & to some extent & yes \\
\hline $\begin{array}{l}\text { Dislodges } \\
\text { solid heels }\end{array}$ & no & no & no & perhaps & yes & yes & yes & no & $\begin{array}{l}\text { if close to } \\
\text { mixer pump }\end{array}$ \\
\hline Power & $\begin{array}{l}7.5 \text { to } 15 \\
\mathrm{~kW}(10 \text { to } \\
20 \mathrm{hp}) \\
\end{array}$ & tbd & tbd & $\begin{array}{l}186 \mathrm{~kW}(250 \\
\mathrm{hp})\end{array}$ & $\begin{array}{l}149 \mathrm{~kW}(200 \\
\mathrm{hp})\end{array}$ & tbd & tbd & $37 \mathrm{~kW}(50 \mathrm{hp})$ & $\begin{array}{l}224 \mathrm{~kW}(300 \\
\mathrm{hp})\end{array}$ \\
\hline
\end{tabular}




\begin{tabular}{|c|c|c|c|c|c|c|c|c|c|}
\hline Criteria & Pulsed Air & $\begin{array}{c}\text { Pulsating } \\
\text { Mixer Pump }\end{array}$ & $\begin{array}{c}\text { Fluidic } \\
\text { Pulse-Jet } \\
\text { Mixing }\end{array}$ & $\begin{array}{l}\text { C-106 } \\
\text { Sluicer }\end{array}$ & $\begin{array}{c}\text { Borehole- } \\
\text { Miner } \\
\text { Extendible- } \\
\text { Nozzle } \\
\end{array}$ & $\begin{array}{c}\text { Waste- } \\
\text { Retrieval } \\
\text { End Effector }\end{array}$ & $\begin{array}{l}\text { High- } \\
\text { Pressure } \\
\text { Scarifier }\end{array}$ & Flygt Mixer & $\begin{array}{l}\text { Mixer } \\
\text { Pump }\end{array}$ \\
\hline $\begin{array}{l}\text { Deploy- } \\
\text { ment }\end{array}$ & $\begin{array}{l}\text { riser mast, } \\
\text { system } \\
\text { unfolds }\end{array}$ & riser mast & riser mast & riser mast & riser arm & $\begin{array}{l}\text { arm or remote } \\
\text { vehicle }\end{array}$ & $\begin{array}{l}\text { arm or } \\
\text { remote } \\
\text { vehicle }\end{array}$ & $\begin{array}{l}\text { riser mast, } \\
\text { system unfolds }\end{array}$ & $\begin{array}{l}\text { riser mast, } \\
\text { system } \\
\text { remains } \\
\text { under riser }\end{array}$ \\
\hline $\begin{array}{l}\text { Remotely } \\
\text { deployed }\end{array}$ & yes & yes & yes & yes & yes & yes & yes & yes & yes \\
\hline
\end{tabular}




\begin{tabular}{|c|c|c|c|c|c|c|c|c|c|}
\hline Criteria & Pulsed Air & $\begin{array}{c}\text { Pulsating } \\
\text { Mixer Pump }\end{array}$ & $\begin{array}{c}\text { Fluidic } \\
\text { Pulse-Jet } \\
\text { Mixing }\end{array}$ & $\begin{array}{l}\text { C-106 } \\
\text { Sluicer }\end{array}$ & $\begin{array}{c}\text { Borehole- } \\
\text { Miner } \\
\text { Extendible- } \\
\text { Nozzle }\end{array}$ & $\begin{array}{c}\text { Waste- } \\
\text { Retrieval } \\
\text { End Effector }\end{array}$ & $\begin{array}{c}\text { High- } \\
\text { Pressure } \\
\text { Scarifier }\end{array}$ & Flygt Mixer & $\begin{array}{l}\text { Mixer } \\
\text { Pump }\end{array}$ \\
\hline $\begin{array}{l}\text { Maintain- } \\
\text { ability }\end{array}$ & $\begin{array}{l}\text { compressor } \\
\text { located } \\
\text { outside the } \\
\text { tank, plates } \\
\text { submerged } \\
\text { in waste }\end{array}$ & $\begin{array}{l}\text { valves and } \\
\text { compressor } \\
\text { located } \\
\text { outside tank }\end{array}$ & $\begin{array}{l}\text { valves and } \\
\text { compressor } \\
\text { located } \\
\text { outside tank }\end{array}$ & $\begin{array}{l}\text { pump located } \\
\text { outside of } \\
\text { tank, pump } \\
\text { may be } \\
\text { contaminated } \\
\text { based on } \\
\text { source of } \\
\text { fluid }\end{array}$ & $\begin{array}{l}\text { pump located } \\
\text { outside of } \\
\text { tank, pump } \\
\text { may be } \\
\text { contaminated } \\
\text { based on } \\
\text { source of } \\
\text { fluid }\end{array}$ & $\begin{array}{l}\text { pump located } \\
\text { outside of } \\
\text { tank, arm or } \\
\text { vehicle inside } \\
\text { tank, pump } \\
\text { may be } \\
\text { contaminated } \\
\text { based on } \\
\text { source of fluid }\end{array}$ & $\begin{array}{l}\text { pump } \\
\text { located } \\
\text { outside of } \\
\text { tank arm or } \\
\text { vehicle } \\
\text { inside tank }\end{array}$ & $\begin{array}{l}\text { entire mixer } \\
\text { including } \\
\text { motor is } \\
\text { submerged }\end{array}$ & $\begin{array}{l}\text { pump motor } \\
\text { located } \\
\text { above the } \\
\text { tank riser, } \\
\text { pump } \\
\text { internals } \\
\text { submerged } \\
\text { in waste }\end{array}$ \\
\hline Removal & $\begin{array}{l}\text { system must } \\
\text { be collapsed } \\
\text { prior to } \\
\text { removal }\end{array}$ & $\begin{array}{l}\text { system } \\
\text { removed } \\
\text { through riser }\end{array}$ & $\begin{array}{l}\text { system } \\
\text { removed } \\
\text { through } \\
\text { riser }\end{array}$ & $\begin{array}{l}\text { system } \\
\text { removed } \\
\text { through riser }\end{array}$ & $\begin{array}{l}\text { system } \\
\text { removed } \\
\text { through riser }\end{array}$ & $\begin{array}{l}\text { system } \\
\text { removed } \\
\text { through riser }\end{array}$ & $\begin{array}{l}\text { system } \\
\text { removed } \\
\text { through } \\
\text { riser }\end{array}$ & $\begin{array}{l}\text { system must } \\
\text { be collapsed } \\
\text { prior to } \\
\text { removal }\end{array}$ & $\begin{array}{l}\text { system } \\
\text { removed } \\
\text { through riser }\end{array}$ \\
\hline
\end{tabular}


Table 5.4 Comparison of the enhanced removal technologies with the acceptance criteria

\begin{tabular}{|c|c|c|c|}
\hline Number and Criteria & $\begin{array}{l}\text { Technology Meets The } \\
\text { Criteria }\end{array}$ & $\begin{array}{l}\text { Technology Can Be Modified } \\
\text { To Meet Criteria }\end{array}$ & $\begin{array}{l}\text { Technology Cannot Readily Be Modified To Meet } \\
\text { Criteria }\end{array}$ \\
\hline $\begin{array}{l}4.2 .1 \text { Assist waste } \\
\text { mobilization in dead } \\
\text { areas }\end{array}$ & $\begin{array}{l}\text { Pulsed Air } \\
\text { Pulsating Mixer Pump } \\
\text { Fluidic Pulse-Jet Mixing } \\
\text { C-106 Sluicer } \\
\text { Borehole-Miner Extendible-Nozzle } \\
\text { Waste-Retrieval End Effector } \\
\text { High-Pressure Scarifier } \\
\text { Flygt Mixer }\end{array}$ & . & 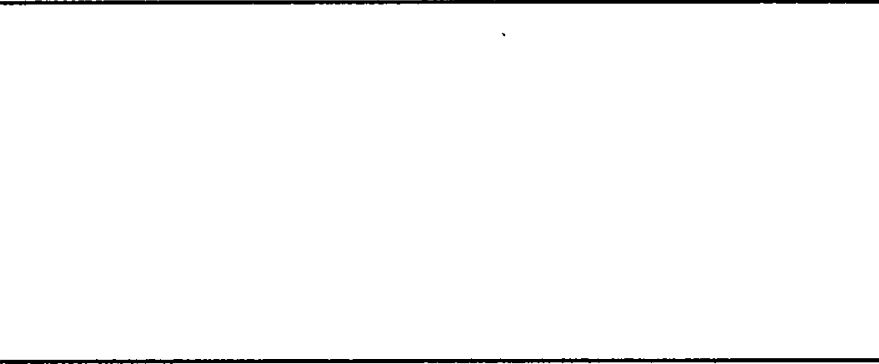 \\
\hline $\begin{array}{l}\text { 4.3.1 Enhance } \\
\text { mobilization for a radius } \\
\text { of } 3 \mathrm{~m}(10 \mathrm{ft})\end{array}$ & $\begin{array}{l}\text { C-106 Sluicer } \\
\text { Borehole-Miner Extendible-Nozzle }\end{array}$ & $\begin{array}{l}\text { Pulsed Air } \\
\text { Pulsating Mixer Pump } \\
\text { Fluidic Pulse-Jet Mixing } \\
\text { Waste-Retrieval End Effector } \\
\text { High-Pressure Scarifier } \\
\end{array}$ & \\
\hline $\begin{array}{l}\text { 4.3.1 Enhance } \\
\text { mobilization of } 1.96 \mathrm{kPa} \\
\left(41 \mathrm{lbf} / \mathrm{ft}^{2}\right) \text { shear } \\
\text { strength sludge }\end{array}$ & $\begin{array}{l}\text { C-106 Sluicer } \\
\text { Borehole-Miner Extendible-Nozzle } \\
\text { Waste-Retrieval End Effector } \\
\text { High-Pressure Scarifier }\end{array}$ & & $\begin{array}{l}\text { Pulsed Air } \\
\text { Pulsating Mixer Pump } \\
\text { Fluidic Pulse-Jet Mixing } \\
\text { Flygt Mixer } \\
\text { The jet performance must be evaluated to determine whether } \\
\text { mobilization of this shear strength sludge could occur at a } \\
\text { radius of } 3 m(10 \mathrm{ft})\end{array}$ \\
\hline $\begin{array}{l}\text { 4.3.4 Pass through } 15.2- \\
\mathrm{cm}-(6-\text {-in.-) diameter } \\
\text { riser }\end{array}$ & $\begin{array}{l}\text { Fluidic Pulse-Jet Mixing } \\
\text { C-106 Sluicer }\end{array}$ & $\begin{array}{l}\text { Pulsed Air } \\
\text { Pulsating Mixer Pump } \\
\text { Borehole-Miner Extendible-Nozzle }\end{array}$ & $\begin{array}{l}\text { Waste-Retrieval End Effector } \\
\text { High-Pressure Scarifier } \\
\text { Flygt Mixer } \\
\text { The design of these devices and their deployment system } \\
\text { would need to be radically modified to fit through a } 15.2-\mathrm{cm} \text { - } \\
\text { (6-in.-) diameter riser }\end{array}$ \\
\hline
\end{tabular}




\begin{tabular}{|c|c|c|c|}
\hline Number and Criteria & \begin{tabular}{|l|} 
Technology Meets The \\
Criteria \\
\end{tabular} & $\begin{array}{l}\text { Technology Can Be Modified } \\
\text { To Meet Criteria }\end{array}$ & $\begin{array}{l}\text { Technology Cannot Readily Be Modified To Meet } \\
\text { Criteria }\end{array}$ \\
\hline $\begin{array}{l}4.2 .2 \text { Detect, locate and } \\
\text { measure accumulation of } \\
\text { residual sludge }\end{array}$ & & & $\begin{array}{l}\text { Pulsed Air } \\
\text { Pulsating Mixer Pump } \\
\text { Fluidic Pulse-Jet Mixing } \\
\text { C-106 Sluicer } \\
\text { Borehole-Miner Extendible-Nozzle } \\
\text { Waste-Retrieval End Effector } \\
\text { High-Pressure Scarifier } \\
\text { Flygt Mixer } \\
\text { None of the technologies are equipped with sensors of this } \\
\text { type }\end{array}$ \\
\hline $\begin{array}{l}4.3 .2 \text { Locate waste } \\
\text { accumulated in a dead } \\
\text { area within } \pm 0.3 \mathrm{~m}(1 \mathrm{ft}) \\
\text { vertically }\end{array}$ & & & $\begin{array}{l}\text { Pulsed Air } \\
\text { Pulsating Mixer Pump } \\
\text { Fluidic Pulse-Jet Mixing } \\
\text { C-106 Sluicer } \\
\text { Borehole-Miner Extendible-Nozzle } \\
\text { Waste-Retrieval End Effector } \\
\text { High-Pressure Scarifier } \\
\text { Flygt Mixer } \\
\text { None of the technologies are equipped with sensors of this } \\
\text { type. }\end{array}$ \\
\hline $\begin{array}{l}\text { 4.5.2 Meets NFPA Class } \\
\text { 1, Div 1, Group B for } \\
\text { flammable gas tank }\end{array}$ & $\begin{array}{l}\text { Pulsed Air } \\
\text { Pulsating Mixer Pump } \\
\text { Fluidic Pulse-Jet Mixing } \\
\text { C-106 Sluicer } \\
\text { Borehole-Miner Extendible-Nozzle }\end{array}$ & $\begin{array}{l}\text { Waste-Retrieval End Effector } \\
\text { High-Pressure Scarifier }\end{array}$ & $\begin{array}{l}\text { Flygt Mixer } \\
\text { The system motor is located inside the tank. }\end{array}$ \\
\hline $\begin{array}{l}4.5 .3 \text { Does not overload } \\
\text { tanks ventilation or } \\
\text { confinement system } \\
\text { [generates }<0.047 \\
\text { standard } \mathrm{m}^{3} / \mathrm{s}(100 \mathrm{scfm}) \\
\text { aerosol] }\end{array}$ & High-Pressure Scarifier & $\begin{array}{l}\text { Pulsed Air } \\
\text { Pulsating Mixer Pump } \\
\text { Fluidic Pulse-Jet Mixing } \\
\text { C-106 Sluicer } \\
\text { Borehole-Miner Extendible-Nozzle } \\
\text { Waste-Retrieval End Effector } \\
\text { Flygt Mixer }\end{array}$ & \\
\hline
\end{tabular}




\begin{tabular}{|c|c|c|c|}
\hline Number and Criteria & $\begin{array}{l}\text { Technology Meets The } \\
\text { Criteria }\end{array}$ & $\begin{array}{l}\text { Technology Can Be Modified } \\
\text { To Meet Criteria }\end{array}$ & $\begin{array}{l}\text { Technology Cannot Readily Be Modified To Meet } \\
\text { Criteria }\end{array}$ \\
\hline $\begin{array}{l}\text { 4.5.4 Does not exceed } \\
\text { tank heat input }[22.4 \mathrm{~kW} \\
(30 \mathrm{hp})]\end{array}$ & $\begin{array}{l}\text { Pulsed Air } \\
\text { Pulsating Mixer Pump } \\
\text { Fluidic Pulse-Jet Mixing } \\
\text { C-106 Sluicer } \\
\text { Borehole-Miner Extendible-Nozzle } \\
\text { Waste-Retrieval End Effector } \\
\text { High-Pressure Scarifier }\end{array}$ & & Flygt Mixer \\
\hline $\begin{array}{l}\text { 4.5.5 Does not exceed } \\
\text { dome-loading limits } \\
{[<11,340 \mathrm{~kg}(25,000} \\
\mathrm{lbm})]\end{array}$ & $\begin{array}{l}\text { Pulsed Air } \\
\text { Pulsating Mixer Pump } \\
\text { Fluidic Pulse-Jet Mixing } \\
\text { C-106 Sluicer } \\
\text { Borehole-Miner Extendible-Nozzle } \\
\text { Waste-Retrieval End Effector } \\
\text { High-Pressure Scarifier } \\
\text { Flygt Mixer } \\
\end{array}$ & & \\
\hline $\begin{array}{l}4.5 .7 \text { Limited liquid } \\
\text { addition }\end{array}$ & $\begin{array}{l}\text { Pulsed Air } \\
\text { Pulsating Mixer Pump } \\
\text { Fluidic Pulse-Jet Mixing } \\
\text { C-106 Sluicer } \\
\text { Borehole-Miner Extendible-Nozzle } \\
\text { Flygt Mixer } \\
\end{array}$ & Waste-Retrieval End Effector & $\begin{array}{l}\text { High-Pressure Scarifier } \\
\text { The } 379 \mathrm{MPa}(55,000 \mathrm{psi}) \text { intensifier pumps operate with } \\
\text { filtered water. }\end{array}$ \\
\hline
\end{tabular}




\section{Deployed Technologies for Enhanced Sludge Removal}

A series of technologies to mobilize, mix, and retrieve waste have been deployed at US Department of Energy sites. Many of these technologies were developed as a part of the Tanks Focus Area Retrieval Process Development and Enhancements project ${ }^{1}$ (Rinker et al. 1996, 1997, Bamberger and Rinker 1996). Some of these technologies may be applicable for enhanced sludge removal at Hanford. Because they have been deployed at radioactive waste sites, these technologies may be more mature with respect to issues specific to deployment at Hanford; therefore, they are grouped together and discussed in this section. Each of the technologies is assessed to determine whether the technology can meet two criteria: 1) be configured for installation in a 15.2-cm- (6-in.-) diameter riser and 2) mobilize sludge with a shear strength of $1.96 \mathrm{kPa}\left(41 \mathrm{lbf} / \mathrm{ft}^{2}\right)$.

\subsection{Fluidic Pulse Jet Mixing}

Fluidic pulse-jet mixing utilizes pulse-jet agitation to mix sludge with liquid supernatant. The system mixes the sludge and supernatant via a three-phase mixing process: a suction phase, a drive phase, and a vent phase, shown in Figure 6.1. This approach has been deployed at Oak Ridge National Laboratory to mobilize and retrieve waste from five horizontal storage tanks (W21, W22, W23, C1, and C2) (Murray and Peters 1999, Kent et al. 1998a, b).

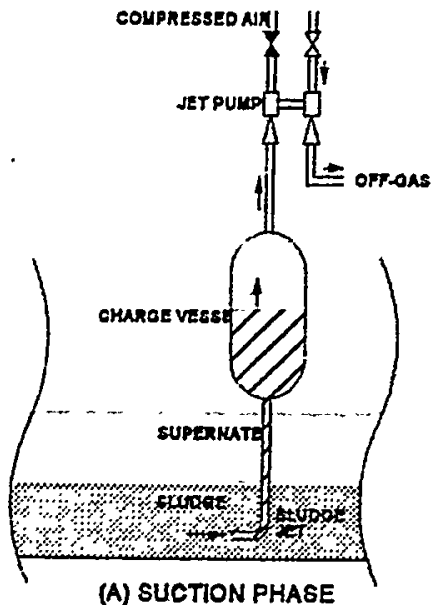

(A) SUCTION PHASE

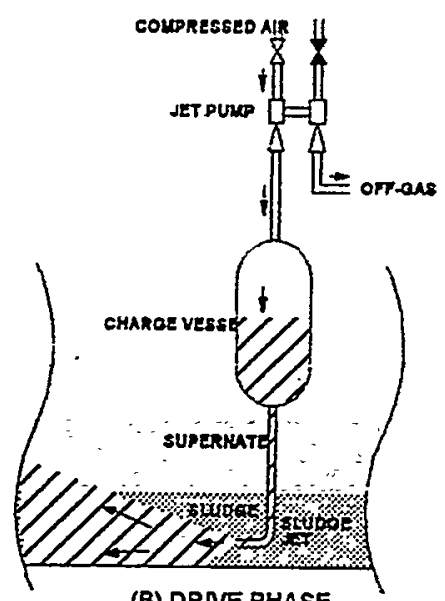

(B) DRNE PHASE

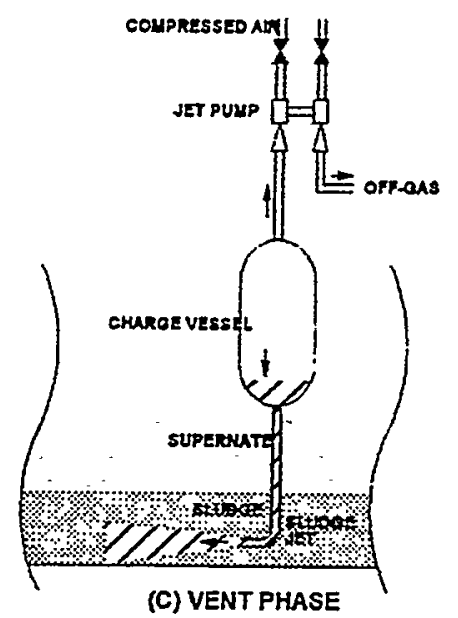

(C) VENT PHASE

Figure 6.1 Pulse jet operating phases

1 Rinker, MW, JA Bamberger, FF Erian, TA Eyre, BK Hatchell, OD Mullen, MR Powell, TJ Samuel, GA Whyatt, and JA Yount. 1998 EM-50 Tanks Focus Area Retrieval Process Development and Enhancements FY98 Technology Development Summary Report. PNNL-12015 Draft, Pacific Northwest National Laboratory, Richland, Washington. 


\subsubsection{Pulse-Jet Mixer Operating Cycle}

During the suction phase, the jet pumps create a partial vacuum in the charge vessel, which in turn draws liquid up from the waste tank into the vessel. Once the charge vessel has been filled with supernatant, the jet pump pressurizes the charge vessel, which drives the supernatant back into the tank; this flow agitates the contents of the tank and resuspends settled solids into the supernatant. This is the drive phase. When the supernatant levels have reached the bottom of the charge vessels, the drive phase is terminated and the charge vessel is depressurized through the jet pump in the vent phase. The cycle is then repeated until the sludge and the supernatant have been mixed.

\subsubsection{Pulse-Jet Mixer System Components}

The pulse-jet mixer system is modular. It consists of the charge vessel assembly, piping manifold, jet pump skid, valve skid, off-gas skid, and control system.

\subsubsection{Charge Vessel Assembly}

The charge vessel assembly includes the charge vessel (with a sludge nozzle at its base), a rotating mechanism to move the nozzle position, and a support assembly that houses the rotating mechanism. The stainless steel charge vessel operates at pressures from vacuum to $0.69 \mathrm{MPa}(100 \mathrm{psi})$. The nozzle at the base is configured to meet the needs of the application. One application used a 3.8-cm-(1.5-in.-) diameter forward facing nozzle and a 1.0-cm-(0.375-in.-) diameter rear-facing nozzle attached to a 7.62-cm-(3-in.-) diameter pipe. The purpose of the smaller nozzle was to clear sludge away from the tank wall; the purpose of the larger nozzle was to mobilize the majority of sludge toward the center of the tank.

\subsubsection{Jet Pump Skid}

The air line piping that connects the jet pump to the charge vessel extends vertically upward to barometrically protect the jet pumps so that no sludge would be able to reach the jet pumps during the

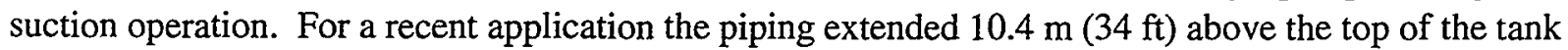
being mobilized. A charge vessel requires two jet pumps, a drive jet pump and a suction jet pump as shown in Figure 6.2. The diffuser end of each drive pump is connected to the charge vessel. The diffuser end of each suction pump is connected to the off-gas system. The inlets to both of the paired pumps are connected to the compressed air supply via the piping manifold and valve skid.

\subsubsection{Off-Gas Skid}

During the vent phase of the pulse-jet mixing system, gas is vented from the charge vessels via jet pumps. The off-gas will have been in contact with contaminated supernatant in the charge vessel; therefore, a protective off-gas system is required. The off-gas first passes through a demister; the 
demister drain line could be routed back into the tank. At ORNL the off-gas intermittent flow rate ranged from 0 to $0.40 \mathrm{~m}^{3} / \mathrm{s}$ [ 0 to $850 \mathrm{cfm}(0$ to $4000 \mathrm{l} / \mathrm{s}$ )], sufficient capacity to operate two charge vessels simultaneously.

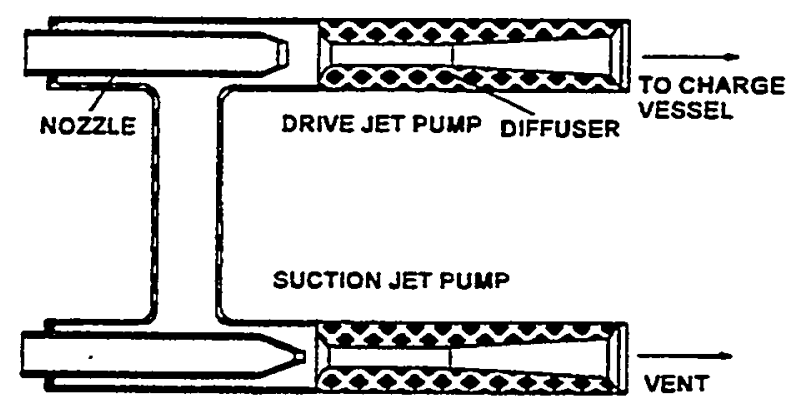

(a) JET PUMP PAIR

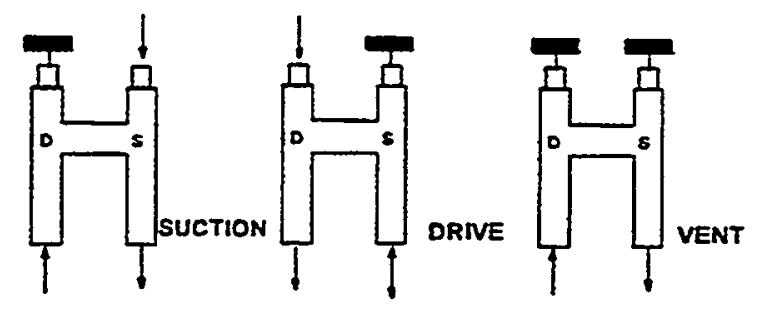

(b) OPERATING MODES

Figure 6.2 Jet pump configuration and operation

\subsubsection{Pulse-Jet Mixer Performance}

The rheological properties of the ORNL sludge were evaluated. The maximum shear strength observed was $20 \mathrm{~Pa}\left(0.42 \mathrm{lbf} / \mathrm{ft}^{2}\right), 100$ times less than that anticipated in the Hanford high level waste. Tests using china clay with a shear strength of $16 \mathrm{~Pa}\left(0.33 \mathrm{lbf} / \mathrm{ft}^{2}\right)$ as a waste simulant were also conducted at ORNL.

Kent (et al. 1998a, b) reports that the pulse-jet mixer skids were installed at ORNL over a period of 7 weeks. The system was operated remotely for 52 days; during that period, $88 \%$ of existing sludge was removed from a $189-\mathrm{m}^{3}$ (50,000-gal) horizontal tank. $242 \mathrm{~m}^{3}$ (64,000 gal) of liquid was required to transfer $23.6 \mathrm{~m}^{3}$ ( $\left.6300 \mathrm{gal}\right)$ of sludge. $88 \%$ of the liquid used was existing or recycled tank supernatant. Only $29.4 \mathrm{~m}^{3}$ (7770 gal) of process water was added to the system. Kent also reports that a simple manual sluicer was used periodically to wash down and aid the removal of localized sludge heels.

Murray and Peters (1999) reported that the campaign to retrieve waste from Tanks C-1 and C-2 was to be initiated in early 1999. Dahl et al. (1999) described the results from these transfers. Tank C-2 was emptied first. A total of $30.7 \mathrm{~m}^{3}$ (8100 gal) of sludge, $99 \%$, was transferred to Tank W-23. After the 
charge vessels were moved from Tank C-2 to Tank C-1, approximately $11.7 \mathrm{~m}^{3}$ (3100 gal) of sludge (95\%) were transferred from Tank C-1 to Tank W-23. Total waste removed from Tank W-23, as a result of this and an earlier campaign, was $71.1 \mathrm{~m}^{3}(18,775 \mathrm{gal})$, almost $99 \%$.

\subsubsection{Pulse-Jet Mixer Deployment for Enhanced Sludge Retrieval}

The pulse-jet mixer piping can be configured to fit through a 15.2-cm- (6-in.-) diameter riser. The charge vessel assembly would need to be located above the tank.

The pulse-jet mixer data indicates that the system was only used to resuspend slurries with very low shear strengths. Testing would be required to determine the effective cleaning radius for slurries and sludges with shear strengths of $1.96 \mathrm{kPa}\left(41 \mathrm{lbf} / \mathrm{ft}^{2}\right)$.

\subsection{Borehole-Miner Extendible-Nozzle Sluicer}

The borehole-miner extendible-nozzle sluicer, shown in Figure 6.3, uses a semi-flexible, extendible, erectable arm to direct a high-pressure sluicer jet. The arm extension and position are controlled remotely from a control console. This system was deployed at Oak Ridge National Laboratory to dislodge and remediate four horizontal underground radioactive waste tanks in 1998 (Bamberger et al. 1998, 1999a, b).

\subsubsection{Extendible-Nozzle Operation}

The extendible nozzle uses supernatant to form a low-flow-rate, high-pressure fluid jet. The nozzle diameter ranges from 0.51 to $1.02 \mathrm{~cm}(0.2$ to $0.4 \mathrm{in}$.) diameter, operating pressures range from line pressure up to $20.7 \mathrm{MPa}\left(3000 \mathrm{psi}\right.$ ), and flow rates range from 0.0032 to $0.0095 \mathrm{~m}^{3} / \mathrm{s}$ (50 to $150 \mathrm{gal} / \mathrm{min}$ ). The jet range is up to $15.2 \mathrm{~m}(50 \mathrm{ft})$ stand-off distance, and the arm can extend up to $3 \mathrm{~m}(10 \mathrm{ft})$, providing a potential reach of $18.3 \mathrm{~m}(60 \mathrm{ft})$. Using supernatant as the jet fluid limits water addition to system flushing activities at the end of daily operation. Specifications for the system deployed at Oak Ridge are listed in Table 6.1.

\subsubsection{Extendible-Nozzle System Components}

The extendible-nozzle system includes the mast, pump, piping, and ventilation system. 

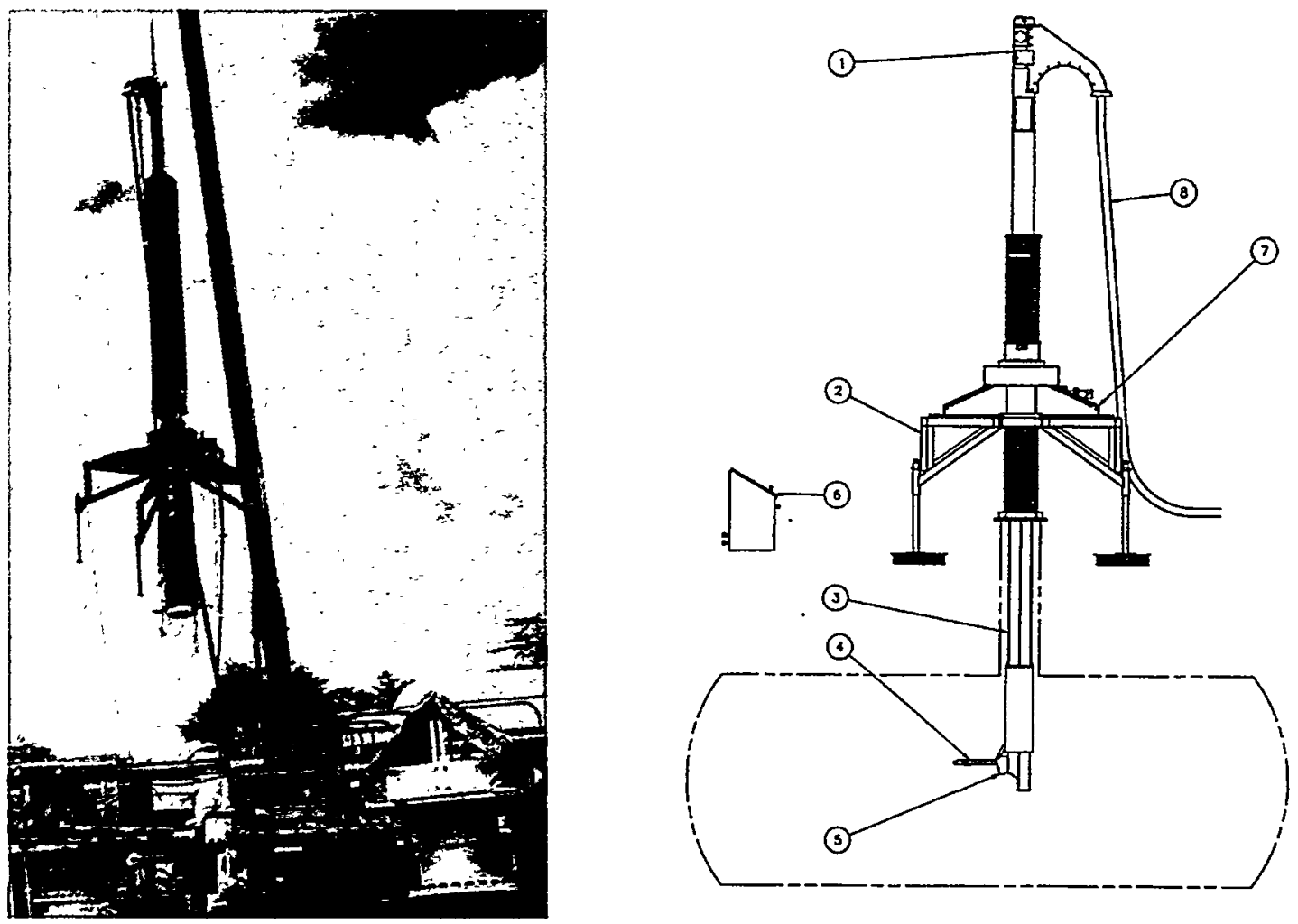

Figure 6.3 Extendible nozzle deployment and configuration

Legend: 1) top mast assembly, 2) platform assembly, 3) lower mast assembly, 4) arm assembly, 5) launch assembly, 6) control console, 7) bridge mount, and 8) containment hose assembly

\subsubsection{Mast}

The mast houses the extendible-nozzle arm. The arm consists of small metallic links that are held together with tensioning cables. The arm links mesh together by cylindrically shaped bearings and bearing sockets (pivot points). The $20.7 \mathrm{MPa}$ (3000 psi) water hose runs through the center of the arm links. The arm is extended and retracted into the mast by a hydraulic motor-driven chain and tie rod system. While tensioned, the arm can be deployed radially to a distance of $3 \mathrm{~m}$ ( $10 \mathrm{ft}$ ) from the mast centerline, and also from a horizontal position to vertically downward. In addition, the mast and nozzle assembly can be rotated \pm 180 degree to give complete coverage of the tank. Movement and tensioning of the arm are accomplished hydraulically, and the arm's position and extension are determined by potentiometer-type encoders.

A double-conduit coaxial hose is used to feed the high-pressure water to the inside of the upper mast. The outer shell is constructed from a 6.2-MPa (900-psi) working pressure, 24.8-MPa (3600-psi) burst pressure hose. In the event of a hose burst, the maximum pressure in the shell is estimated to be less than $0.69 \mathrm{MPa}(100 \mathrm{psi})$. 
Table 6.1 Extendible-nozzle specifications

\begin{tabular}{||l|c||}
\hline \hline Description & Specification \\
\hline \hline Maximum slurry line working pressure & $20.7 \mathrm{MPa}(3000 \mathrm{psi})$ \\
\hline Design flow rate & $0.0095 \mathrm{~m}^{3} / \mathrm{s}(150 \mathrm{gpm})$ \\
\hline Maximum arm extension & $3 \mathrm{~m}(10 \mathrm{ft})$ from mast centerline \\
\hline $\begin{array}{l}\text { Arm range of motion } \\
\text { Rotation } \\
\text { Azimuth }\end{array}$ & $\begin{array}{c}180 \text { degree } \\
90 \text { degree (horizontal to vertically downward })\end{array}$ \\
\hline Platform vertical range & $76 \mathrm{~cm}(30$ in. $)$ \\
\hline Weight & $2835 \mathrm{~kg}(6250 \mathrm{lbm})$ \\
\hline Maximum arm extension rate & $25.4 \mathrm{~cm} / \mathrm{s}(10 \mathrm{in} . / \mathrm{s})$ \\
\hline Minimum launch angle rate & $9 \mathrm{degree} / \mathrm{s}$ \\
\hline Mast rotation speed & 0.012 to $1.2 \mathrm{rpm}$ \\
\hline Maximum arm rinse working pressure & $1.0 \mathrm{MPa}(150 \mathrm{psi})$ \\
\hline Maximum spray ring working pressure & $1.7 \mathrm{MPa}(250 \mathrm{psi})$ \\
\hline \hline $\begin{array}{l}\text { Exposed materials. Materials exposed to waste are stainless steel (300 series, } 15 \text { to } 5 \mathrm{pH}), \text { hard } \\
\text { chromium plate, nickel plate, polyurethane enamel-coated carbon steel, polyurethane, neoprene, } \\
\text { polyethylene, nylon. }\end{array}$ \\
\hline
\end{tabular}

The extendible-arm assembly has four mechanical motions: arm tensioning, angle positioning, arm extension, and mast rotation. Each of these four motions is accomplished with a single independent hydraulic manifold. Each manifold is supplied with a joystick-operated, manual, flow-control valve. The four joy sticks are the interface between the operator and the motion. During sluicing, the position of the extendible nozzle was controlled manually using the control console. A lifting shackle to carry the weight of the mast and mast mount assemblies is located at the top end of the mast. A fulcrum is located as the bottom of the mast so that the mast can be pinned to a support structure and put in a lay down position.

The mast length is designed for each application and is based on the height of the tank. When deployed at ORNL the extendible nozzle was designed for dimensions of $4.5 \mathrm{~m}$ (14.9) $\mathrm{ft}$ from grade to tank bottom and $2.4 \mathrm{~m}(8 \mathrm{ft})$ diameter; the mast was approximately $8.8 \mathrm{~m}(29 \mathrm{ft})$ in length and was made up of two sections with a bolted flange joint. A design, for deployment at Savannah River Site Tank 19 with dimensions of $13.7 \mathrm{~m}$ (45.1 ft) from grade to tank bottom tank and $13.0 \mathrm{~m}(42.5 \mathrm{ft})$ high; required mast length extensions to permit deployment in a deeper tank. The Savannah River site design is very similar to that required for deployment at Hanford. Hanford $3875 \mathrm{~m}^{3}$ (million-gal) tanks are

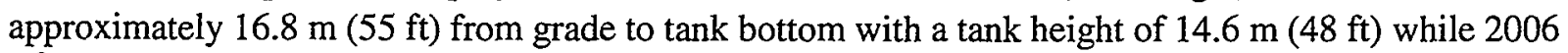
$\mathrm{m}^{3}(530,000 \mathrm{gal})$ tanks are approximately $11.3 \mathrm{~m}(37 \mathrm{ft})$ from grade to tank bottom with a tank height of $9.5 \mathrm{~m}(31.25 \mathrm{ft})$.

The mast support mount consists of a bridge mount assembly that is bolted to a portable platform over the tank riser and supports the mast assembly at the desired elevation over the tank floor. To ensure 
that no radioactivity will escape through the mast, the mast mount assembly includes a bellows-type expanding containment cover, shown in Figure 6.3, which encloses the portion of the mast that will be exposed to tank waste. A clamp-on cover plate is used to close the end of the containment cover during storage. A second bellows cover is located between the bridge mount and riser flange. An interface flange is located at the bottom of the cover to attach to the riser. During transfers from tank-to-tank, the bottom of the second bellows is sealed to enclose the extendible-nozzle components.

\subsubsection{Sluicer Pump Skid}

The sluicer pump skid includes the high-pressure pump, variable-speed drive, valves, and instrumentation to control and monitor the pump pressure.

\subsubsection{Pumping System}

The primary components of the pumping system are:

- Low-pressure transfer pump to transfer contents from the sluicing tank to the mixing tank

- Mixer in mixing tank to maximize slurry mixing

- Low-pressure feed pump [1.4 MPa (200 psi) progressive cavity Moyno pump] to lift contents from the mixing tank and feed to the high-pressure pump

- Strainer to remove larger particles from the feed to the nozzle

- Process water system used to flush the lines after transfer and provide other process water needs at the site

- Associated piping and valves including tank drop legs and riser modifications

- Containment piping, riser confinement boxes and confinement skid enclosures.

\subsubsection{Ventilation System}

The primary components of the ventilation system are:

- High-efficiency particulate air (HEPA) filter system on the air intake to minimize treatment HEPA loading and minimize discharges to atmosphere in the event of a ventilation system shutdown

- Demister to remove water vapor from the air stream

- Heater to reduce the relative humidity of the air stream

- Primary and secondary HEPA system to filter air discharged from the ventilation system

- Single-speed fan to drive the air flow

- Discharge stack and associated stack monitoring.

\subsubsection{ORNL Configuration Extendible-Nozzle Weight}

The bridge mount and stand are estimated to weigh $1361 \mathrm{~kg}$ (3600 lbm). The combined weight of the mast and bridge mount is estimated to be $\sim 2880 \mathrm{~kg}(6350 \mathrm{lbm})$, distributed over an area $2.4 \mathrm{~m} \mathrm{x} 2.4 \mathrm{~m}$ (8 
$\mathrm{ft} x 8 \mathrm{ft}$ ) on the surface. The maximum force load that is transferred to the supporting surface (ground) as a result of the jet thrust moment is $\sim 481 \mathrm{~kg}(1060 \mathrm{lbm}$ ) (at maximum jet thrust with the moment load taken on one leg of the stand). The mast weight is estimated to be $\sim 1247 \mathrm{~kg}(2750 \mathrm{lbm})$. Lifting shackles to carry the weight of the bridge mount during installation and removal are incorporated in the bridge mount structure.

\subsubsection{Extendible-Nozzle Operating Experience and Performance}

The borehole miner extendible nozzle was deployed at Oak Ridge National Laboratory to mobilize and $\operatorname{mix} 159 \mathrm{~m}^{3}(42,000 \mathrm{gal})$ of low level waste stored in five horizontal underground storage tanks. The tanks contained $45.7 \mathrm{~cm}$ (18 in.) of sludge covered by supernate. In 1998, over a period of less than 3 weeks, the borehole-miner extendible-nozzle system was deployed to remediate these tanks.

Prior to deployment at ORNL, tests were conducted at Pacific Northwest National Laboratory to characterize the performance of the borehole-miner extendible-nozzle. The tests were conducted using sludge waste simulants with shear strengths ranging from 2 to $150 \mathrm{kPa}$ (42 to $3133 \mathrm{lbf} / \mathrm{ft}^{2}$ ) and salt cake simulants with compressive strengths up to $19 \mathrm{MPa}\left(396,825 \mathrm{lbf} / \mathrm{ft}^{2}\right)$. The nozzle stand-off distances evaluated ranged from 1.5 to $15 \mathrm{~m}$ ( 5 to $50 \mathrm{ft}$ ). The borehole-miner extendible-nozzle was able to dislodge and mobilize simulants with this broad range of physical and rheological properties.

The extendible-nozzle system at ORNL was designed to penetrate through a $30.5-\mathrm{cm}$ (12-in.) riser. The mast, hose, and extension mechanism could be reconfigured to be deployed through a 15.2-cm- (6in.-) diameter riser. A configuration for extended sludge resuspension would probably not require an

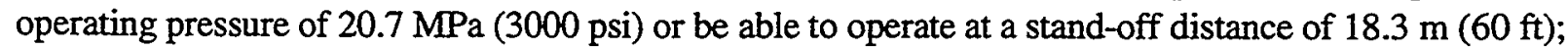
therefore, the system size could be reduced for this application.

\subsubsection{Extendible-Nozzle Deployment for Enhanced Sludge Removal}

The extendible-nozzle can be configured to fit through a 15.2-cm- (6-in.) diameter riser. The nozzle length of extension would be configured so that the unit could be deployed to reach specified areas to dislodge and mobilize waste with the nozzle water jet.

The extendible-nozzle performance data indicate that the system is well suited for dislodging and moving waste with physical properties that are much more challenging than the specified shear strength of $1.96 \mathrm{kPa}\left(41 \mathrm{lbf} / \mathrm{ft}^{2}\right)$. Testing would be required to determine the effective cleaning radius for slurries and sludges with shear strengths of $1.96 \mathrm{kPa}\left(41 \mathrm{lbf} / \mathrm{ft}^{2}\right)$; it is expected that the ECR would be on the order of the extendible nozzle range of 15.2 to $18.3 \mathrm{~m}$ (50 to $60 \mathrm{ft}$ ) stand-off distance. 


\subsection{C-106 Sluicer}

Hanford Project W-320 installed the waste retrieval sluicing system (WRSS) in Tank 106-C to mobilize high-heat generating sludge in Tank 106-C to transfer it to Tank 102-AY. The tank was classified as a high heat watch list tank with a heat load estimated to be $34.6 \mathrm{~kW}(118,000 \mathrm{Btu} / \mathrm{hr})$,

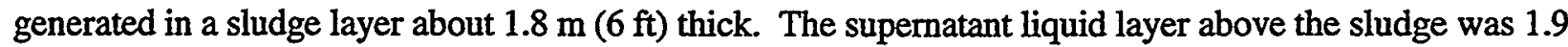
$\mathrm{m}$ (77 in.) deep, varying over the range from 1.92 to $1.99 \mathrm{~m}$ (75.6 to $78.4 \mathrm{in}$.) due to evaporation and the addition of cooling water every 20 to 30 days. These additions were typically on the order of 7.6 to 11.4 $\mathrm{m}^{3}$ (2000 to $3000 \mathrm{gal}$ ) and raised the tank liquid level by approximately $2.54 \mathrm{~cm}$ (1 in.). Evaporation would subsequently lower the liquid level at a steady rate until the next addition. The process flow sheet, shown in Figure 6.4, defines system components, operating pressures and flow rates; the sluicer details are shown in Figure 6.5 (Carothers et al. 1999).

\subsubsection{Sluicer System Components}

The sluicer is constructed of $304 \mathrm{~L}$ stainless steel and has a $2.54-\mathrm{cm}$ - (1-in.-) diameter nozzle with two degrees of motion control (rotation 194 degrees) and nozzle elevation (130 degrees). The nozzle pivots/rotates at a fixed elevation in the tank and can be aimed with a dedicated hydraulic system. The sluicer controls can be operated in manual or semi-automatic mode.

The sluicer pump system is a tandem pump that includes an adjustable height, submersible slurry pump in the tank and a variable-speed slurry booster pump in the pit above (May 1996). The submersible slurry pump is a centrifugal, direct-drive, end suction, $30-\mathrm{kW}(40-\mathrm{hp})$ immersible pump with a $0.6-\mathrm{cm}-$ (0.25-in.-) mesh intake screen. The submersible pump pumps waste from the tank to the $186-\mathrm{kW}$ (250-hp vertical direct-drive, variable-speed, centrifugal slurry booster pump. The sluicer is approximately 29.2 $\mathrm{cm}$ (11.5 in.) in diameter and is installed in a 30.5 (12-in.)-diameter riser. 


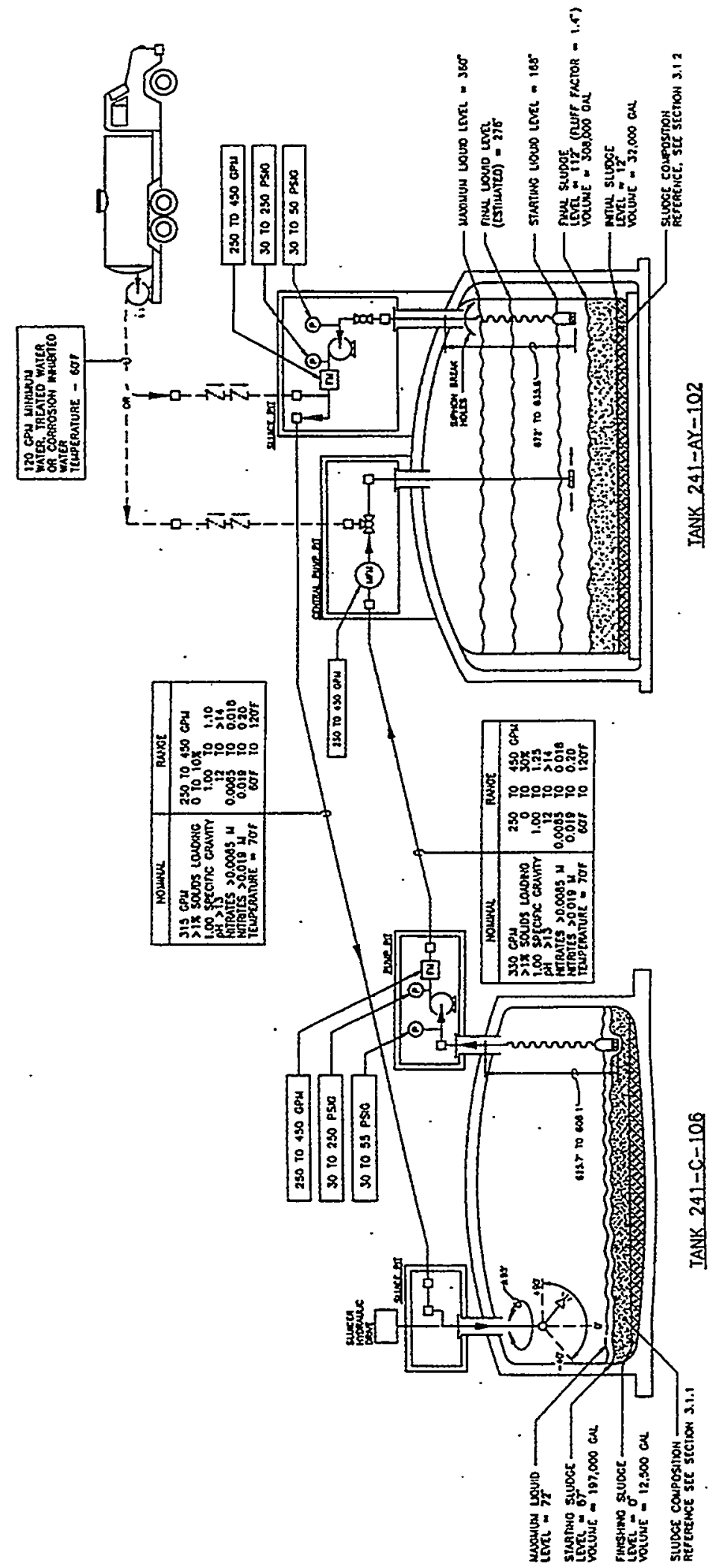

Figure 6.4 Tank 106-C process flow sheet

$$
6.10
$$




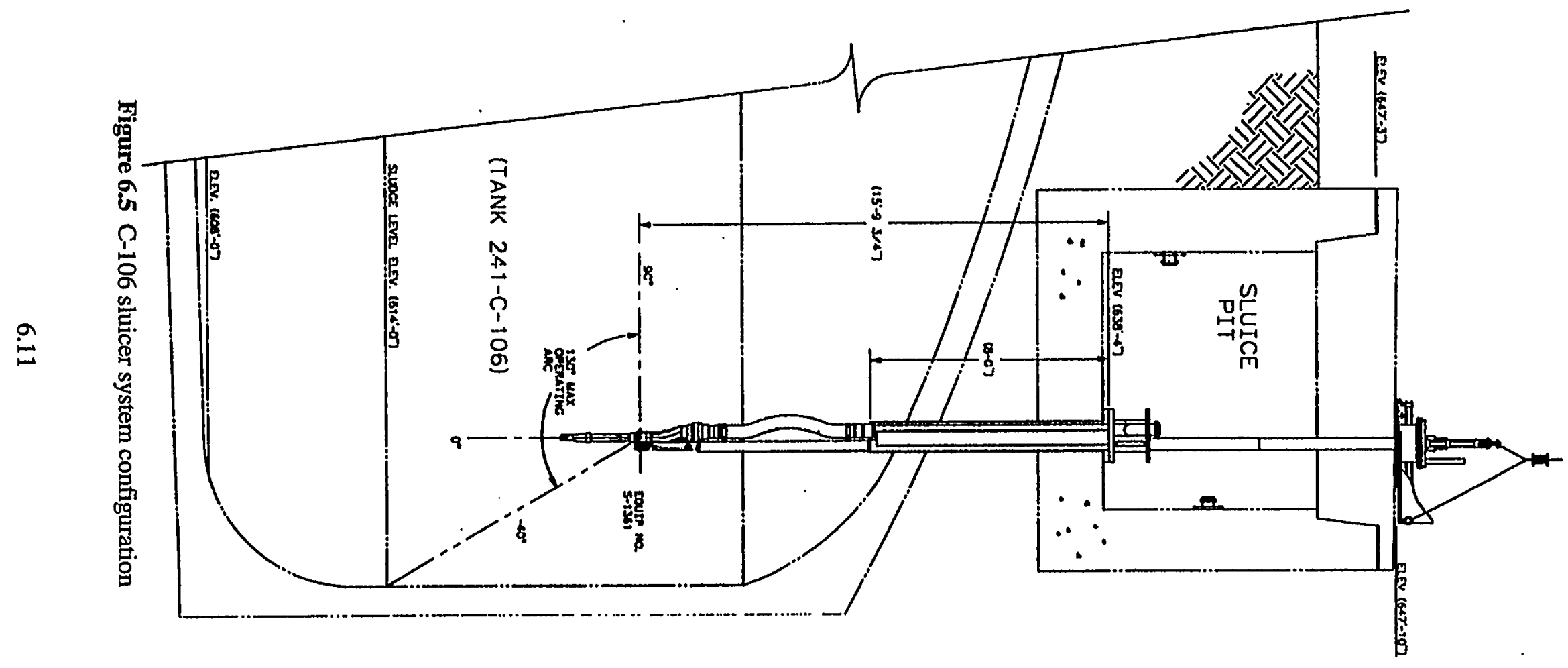




\subsubsection{Sluicer Operation}

The sluice nozzle orientation is hydraulically controlled. The nozzle swings through a 130 degree vertical arc, from horizontal to $-40 \mathrm{deg}$. On the horizontal axis, the sluicer can sweep in a $194 \mathrm{deg}$ arc. The sluicer can operate in a fixed position, sweep in an automatic mode, or be controlled by the joy stock. Maximum operating pressure is $2.07 \mathrm{MPa}$ (300 psi). The nominal sluicer flow rate is $0.022 \mathrm{~m}^{3} / \mathrm{s}$ [ 350 $\mathrm{gal} / \mathrm{min}(140 \mathrm{ft} / \mathrm{s})]$; the minimum flow rate to keep solids in suspension is $0.019 \mathrm{~m}^{3} / \mathrm{s}[300 \mathrm{gal} / \mathrm{min}$ (120 $\mathrm{ft} / \mathrm{s})]$. The system safety limit is $0.041 \mathrm{~m}^{3} / \mathrm{s}$ [650 gal/min $\left.(270 \mathrm{ft} / \mathrm{s})\right]$. Nozzle horizontal and vertical position is indicated on the sluicer controller. The sluice stream can also be monitored on the video monitor in the control trailer. The sluicer was used to mobilize the waste in phases. The proposed operation is shown in Figure 6.6. The actual operations are summarized in Table 6.2.'

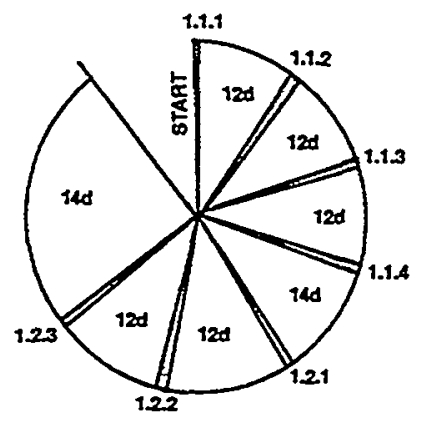

CAMPAIGN 1

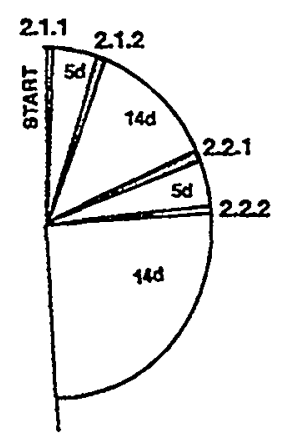

CAMPAIGN 2

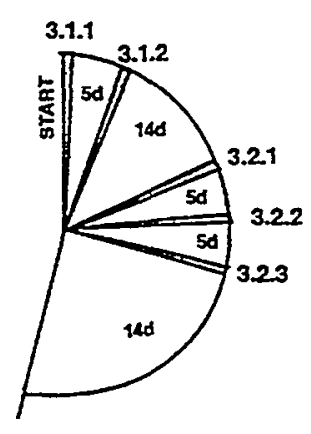

CAMPAIGN 3

Notation: $X Y Z$

X-campaign

Y-bateh

Figure 6.6 Planned sluicer operation

\subsubsection{Sluicer Performance}

The sluicer has been successfully operated between November 1998 and October 1999 to sluice waste in Tank C-106. No information regarding the waste theology is available. This lack of information suggests that the shear strength is not a significant issue. The liquid density is $\sim 1.2 \mathrm{~g} / \mathrm{cm}^{3}\left(74.92 \mathrm{lbm} / \mathrm{ft}^{3}\right)$, the sludge bulk density is $1.6 \mathrm{~g} / \mathrm{cm}^{3}\left(99.89 \mathrm{lbm} / \mathrm{ft}^{3}\right)$, and the waste particulate density is $2.6 \mathrm{~g} / \mathrm{cm}^{3}(162.3$ $\left.\mathrm{lbm} / \mathrm{ft}^{3}\right)$.

${ }^{1}$ Cuta, J.M., K.G. Carothers, D.W. Damschen, J.A. Lechelt, B.E. Wells, K. Sathyanarayana, and L.A. Stauffer. 1999. Review of Waste Retrieval Sluicing System Operations and Tank Data for 241-C-106 and 241-AY-102. Draft. Pacific Northwest National Laboratory, Richland, Washington. 
Table 6.2 History of Tank 106-C sluicing transfers

\begin{tabular}{|c|c|c|c|c|c|c|c|}
\hline \multirow[t]{2}{*}{ Date } & $\begin{array}{l}\text { Heat Load } \\
\text { Transferred } \\
\text { in Batch }\end{array}$ & $\begin{array}{l}\text { Sludge } \\
\text { Volume }\end{array}$ & $\begin{array}{l}\text { Net Heat } \\
\text { Load } \\
\text { Transferred }\end{array}$ & $\begin{array}{l}\text { Net Sludge } \\
\text { Transferred, }\end{array}$ & \multirow[t]{2}{*}{$\begin{array}{l}\text { Cam- } \\
\text { paign } \\
\text { Phase }\end{array}$} & \multirow{2}{*}{$\begin{array}{l}\text { Plan- } \\
\text { ned } \\
\text { Dur- } \\
\text { ation } \\
\text { da }\end{array}$} & \multirow{2}{*}{$\begin{array}{l}\text { Actual } \\
\text { Dur- } \\
\text { ation } \\
\text { da }\end{array}$} \\
\hline & $\begin{array}{|ll|}\mathbf{k W} & \mathbf{B t u} / \mathbf{h r} \\
\end{array}$ & gal & $\mathbf{k W} \quad$ Btu/hr & gal & & & \\
\hline $11 / 18 / 98$ & 0.199 & 29.567810 & 0.199 & 29.56 & 1.1 .1 & 12 & 28 \\
\hline $12 / 16 / 98$ & 0.144 & 8.7442310 & $\begin{array}{ll}0.343 & 1171\end{array}$ & $\begin{array}{ll}38.31 & 10120\end{array}$ & $\begin{array}{l}\text { Process } \\
\text { Test, } \\
\text { Phase } 1\end{array}$ & & 81 \\
\hline $3 / 7 / 99$ & 0.804 & 88.2723320 & $1.147 \quad 3918$ & $126.6 \quad 33440$ & $\begin{array}{l}\text { Process } \\
\text { Test, } \\
\text { Phase } 2\end{array}$ & & 21 \\
\hline $3 / 28 / 99$ & 2.211 & 158.941965 & $3.359 \quad 11465$ & 285.475405 & $\begin{array}{l}\text { Process } \\
\text { Test, } \\
\text { Phase } 3\end{array}$ & & 26 \\
\hline $\begin{array}{l}\text { Total for } \\
\text { Campaign } \\
\# 1\end{array}$ & $\begin{array}{|ll|}3.359 & 11465 \\
\end{array}$ & 285.475405 & & & & 88 & 156 \\
\hline $4 / 23 / 99$ & 0.0969 & \begin{tabular}{|ll}
6.98 & 1843 \\
\end{tabular} & $3.455 \quad 11797$ & $292.4 \quad 77248$ & 2.1 .1 & 5 & 5 \\
\hline $\begin{array}{l}4 / 28 / 99 \text { and } \\
4 / 30 / 99\end{array}$ & 0.927 & 55.2814603 & $4.968 \quad 16963$ & $\begin{array}{ll}47.7 & 91851\end{array}$ & 2.1 .2 & 14 & 26 \\
\hline $5 / 24 / 99$ & $0.0536 \quad 1830$ & $25.30 \quad 6683$ & $\begin{array}{ll}4.918 & 16793\end{array}$ & $373.0 \quad 98534$ & 2.2 .1 & 5 & 10 \\
\hline $6 / 3 / 99$ & 2.641 & 107.328353 & 0.075825809 & 480.3126887 & 2.2 .2 & 14 & 48 \\
\hline $\begin{array}{l}\text { Total for } \\
\text { Campaign } \\
\text { \#2 }\end{array}$ & $\begin{array}{|ll|}4.201 & 14344 \\
\end{array}$ & 194.951482 & & & & 38 & 89 \\
\hline $\begin{array}{l}7 / 21 / 99 \text { and } \\
7 / 22 / 99\end{array}$ & $0.0155 \quad 5208$ & 50.5913365 & $9.084 \quad 31017$ & $530.9 \quad 140252$ & $\begin{array}{l}3.1 .1 \\
\text { (part 1) }\end{array}$ & 5 & 14 \\
\hline $8 / 4 / 99$ & 0.132 & $\begin{array}{ll}4.37 & 1155 \\
\end{array}$ & $9.216 \quad 31467$ & $\begin{array}{ll}535.3 & 141407 \\
\end{array}$ & 3.1 .2 & 14 & 16 \\
\hline $8 / 20 / 99$ & 0.535 & $20.19 \quad 5335$ & $9.751 \quad 33293$ & $555.5 \quad 146742$ & 3.1 .3 & & 21 \\
\hline $9 / 10 / 99$ & \begin{tabular}{|l|}
0.977 \\
\end{tabular} & $33.73 \quad 8910$ & $10.73 \quad 36630$ & $\begin{array}{ll}589.2 & 155652 \\
\end{array}$ & 3.2 .1 & 5 & 4 \\
\hline $9 / 14 / 99$ & \begin{tabular}{|l|}
0.534 \\
\end{tabular} & $18.43 \quad 4868$ & $11.26 \quad 38453$ & $607.6 \quad 160520$ & 3.2 .2 & 5 & 2 \\
\hline $9 / 16 / 99$ & \begin{tabular}{|l|}
1.121 \\
\end{tabular} & 44.5511770 & $12.38 \quad 42281$ & $690.0 \quad 172290$ & 3.2 .3 & 14 & 5 \\
\hline $9 / 21 / 99$ & 0.477 & $18.95 \quad 5005$ & $12.86 \quad 43908$ & $671.1 \quad 177295$ & 3.2 .4 & & 3 \\
\hline $9 / 24 / 99$ & 0.339 & $\begin{array}{ll}13.85 & 3658 \\
\end{array}$ & $13.20 \quad 45068$ & $685.0 \quad 180952$ & 3.2 .5 & & 2 \\
\hline $9 / 26 / 99$ & 0.232 & $9.47 \quad 2503$ & $\begin{array}{ll}13.43 \quad 45861 \\
\end{array}$ & $694.4 \quad 183455$ & 3.2 .6 & & 2 \\
\hline $9 / 28 / 99$ & 0.102 & $\begin{array}{ll}4.16 & 1100 \\
\end{array}$ & $13.53 \quad 46210$ & $\begin{array}{ll}698.6 & 184555 \\
\end{array}$ & 3.2 .7 & & 2 \\
\hline 9/30/99 & 0.120 & \begin{tabular}{|ll}
4.89 & 1293 \\
\end{tabular} & $13.65 \quad 46619$ & $\begin{array}{ll}703.5 & 185847 \\
\end{array}$ & 3.2 .8 & & 6 \\
\hline $10 / 06 / 99$ & 0.357 & $1.46 \quad 385$ & 13.6946741 & $704.9 \quad 186232$ & 3.2 .9 & & \\
\hline $\begin{array}{l}\text { Total for } \\
\text { Campaign } \\
\# 3\end{array}$ & $\begin{array}{|ll|}6.13 & 20932 \\
\end{array}$ & 224.659345 & & & & 43 & 77 \\
\hline $\begin{array}{l}\text { Total for } \\
\text { entire } \\
\text { sluicing } \\
\text { operation } \\
\end{array}$ & & & 13.6946741 & $\begin{array}{ll}704.9 & \\
& 186232\end{array}$ & & & \\
\hline
\end{tabular}




\subsubsection{Sluicer Deployment for Enhanced Sludge Removal}

The sluicer current design is for insertion through a riser with a diameter much larger than $15.2 \mathrm{~cm}$ ( 6 in.) It is expected that the sluicer may be redesigned to be installed through a $15.2-\mathrm{cm}$ - (6-in.) diameter riser. Some loss of performance may occur.

\subsection{Pulsed-Air Mixer}

In 1999, Oak Ridge National Laboratory deployed a pulsed-air mixer in Tank W-9 to mix waste solids and accelerate settling of $>100-\mu \mathrm{m}$-diameter particles. Pulse air technology ${ }^{1}$ was identified in 1994 as a potential method to enhance mixing in underground storage tanks. The technology was developed for deployment at ORNL at Pacific Northwest National Laboratory as a part of the Retrieval Process Development and Enhancements project.

\subsubsection{Pulsed-Air Mixer Operation}

The pulsed-air mixing technique utilizes short, discrete pulses of air or inert gas to produce large bubbles near the tank floor. The bubbles are produced beneath horizontal circular plates positioned just above the tank floor. These bubbles rise toward the liquid surface and induce mixing, as shown in Figure 6.7. The pulse frequency, duration, gas pressure, and plate sequencing are controlled to create a wellmixed condition within the tank. Pulsed-air mixing differs from conventional air sparging; in pulsed-air mixing single, large bubbles are introduced into the tank fluid periodically (once every $15 \mathrm{~s}$ ); in sparging, small bubbles are injected continuously. The rapid expansion of the pulsed-air bubbles near the tank floor and their subsequent rise through the fluid serve to both lift solids from the tank floor and maintain those solids in a uniform suspension.

The system deployed at ORNL Tank W-9 utilized a dual-plate pulsed-air mixer; shown in Figure 6.8. In this design air pulses can be applied either to the underside of the bottom plate or between the plates. Pulsing air under the bottom plate clears away sludge and allows the mixer to penetrate through piles of sludge. Once the mixer reaches the floor, air pulses are applied only between the plates. This eliminates the tendency of the plates to lift with each pulse.

1 Andrews, R.M. PTWF Pulsair Tank Waste Fluidizing, September 19 \& 20, 1994, Hanford, Washington. Pulsair Systems, Inc., Bellevue, Washington.

Powell, M.R. and G.A. Whyatt. 1999. ORNL Tank W-9 Pulsed-Air Mixer Design, Defensibility and Performance Evaluation. PNNL-11918 Draft, Pacific Northwest National Laboratory, Richland, Washington.

Powell, M.R, M.A. Sprecher, C.R. Hymas, D. Winkel, R.M. Andrews, and R.E. Park. 1995. 1/12Scale Testing of a Pulsair Mixing Array: An Evaluation of Pulsed-Bubble Mixing for Hanford Waste Retrieval and Processing Applications. March, Pacific Northwest Laboratory, Richland, Washington.

Pulsair Systems, Inc. Pulsair Pneumatic Batch Mixing. 1993. Pulsair Systems, Inc., Bellevue, Washington. 

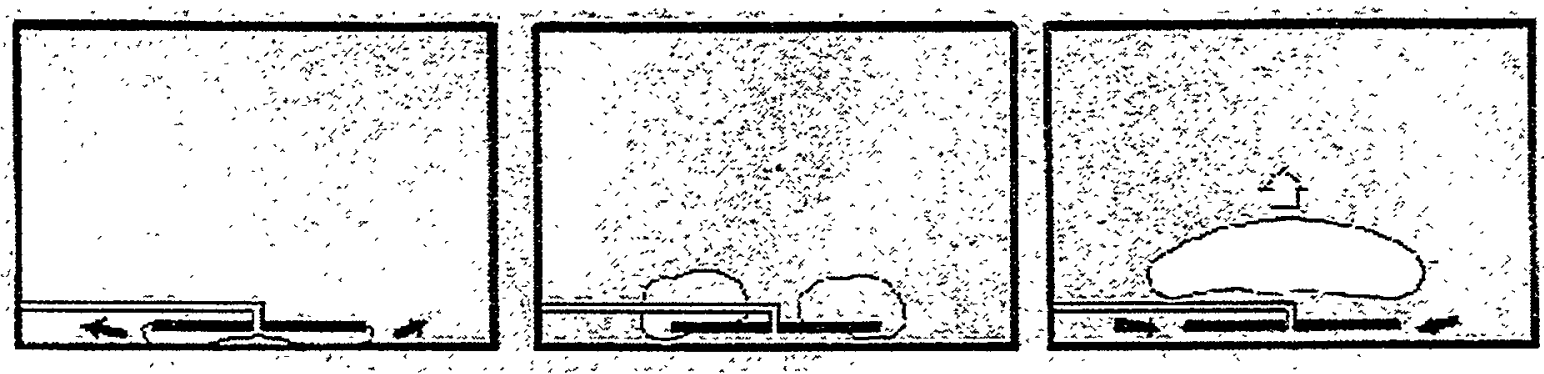

Figure 6.7 Pulsed-air bubble formation, growth, and coalescence. Courtesy of Pulseair Systems, Inc.

\subsubsection{Pulsed-Air Mixer System Components}

The pulsed-air mixer system includes an array of horizontal, circular plates positioned just above the tank floor. Pipes connected to each plate supply pulses of compressed gas to the underside of each plate via special commercially available gas pulsing valves.

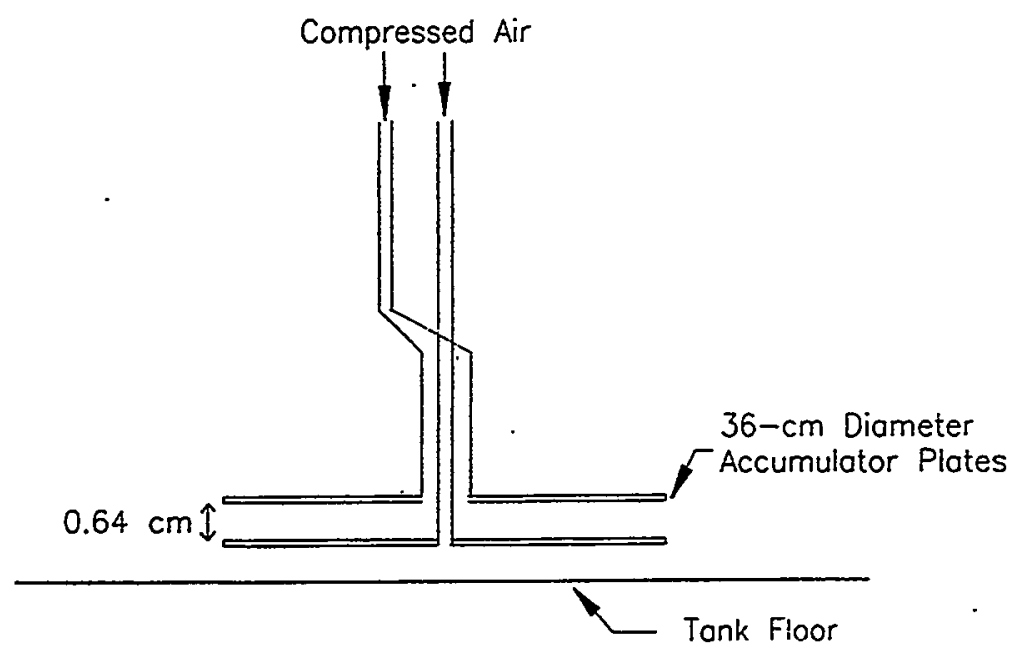

Figure 6.8 Dual-plate pulsed-air mixer configuration

\subsubsection{Mixer}

The ORNL Tank W-9 mixer consists of 13 circular accumulator plates positioned to cover the tank floor. Each plate is $27.9 \mathrm{~cm}$ (11 in.) in diameter and is connected to a $2.54-\mathrm{cm}$ (1-in.) schedule 40 pipe. Each pipe is connected to a compressed air pulsing valve outside of the tank. The mixer plate diameter was selected to fit through the $83.8-\mathrm{cm}-(33-\mathrm{in}$.) diameter tank risers. 


\subsubsection{Deployment System}

To reach positions other than beneath the tank riser, an inverted umbrella deployment system was designed and evaluated. The self-deploying assembly is lowered through the tank riser. When it contacts the tank floor, it unfolds like an inverted umbrella. This concept is shown in Figure 6.9.

\subsubsection{Pulsed-air Controller and Valves}

The mixer controller, gas pulsing valves, and compressed air supply are located outside the tank. The controller permits independent adjustment of pulse rate, plate sequence, and pulse duration. The gas pressure can be adjusted between 0 and $0.69 \mathrm{MPa}$ gauge $(0$ and $100 \mathrm{psig})$ using a pressure regulator located upstream of the $0.30-\mathrm{m}^{3}\left(80\right.$-gal) compressed air storage tank. The $0.30-\mathrm{m}^{3}$ (80-gal) tank provides enough compressed air to pulse 13 plates simultaneously. This valve controls operating pressure and prevents migration of radioactive materials into the compressed air supply. A 0 to $0.069 \mathrm{MPa}$ gauge ( 0 to $10 \mathrm{psig}$ ) pressure regulator on the downstream side of the compressed air tank provides a slow flow of compressed air to each accumulator plate. This pressure keeps waste from entering the pipe and ensures that any waste-bearing aerosols inside the pipes are prevented from migrating up the air pipes to the airpulsing valves.

\subsubsection{Containment and Contamination Control}

During normal mixer operation there are two potential pathways for loss of waste containment: aerosol generation from mixing action within the tank and migration of waste-bearing aerosols up the compressed air pipes against the flow of compressed air. The maximum aerosol loading expected to result from pulsed-air mixing is estimated to be $50 \mathrm{mg}(0.11 \mathrm{lbm})$ of wet aerosol per of cubic meter of gas supplied to the mixer. ${ }^{1}$ This estimate is based on aerosol production rates measured in a variety of experiments.

1 Powell, M.R.and G.A. Whyatt. 1999. ORNL Tank W-9 Pulsed-Air Mixer Design, Defensibility and Performance Evaluation. PNNL-11918 Draft, Pacific Northwest National Laboratory, Richland, Washington. 


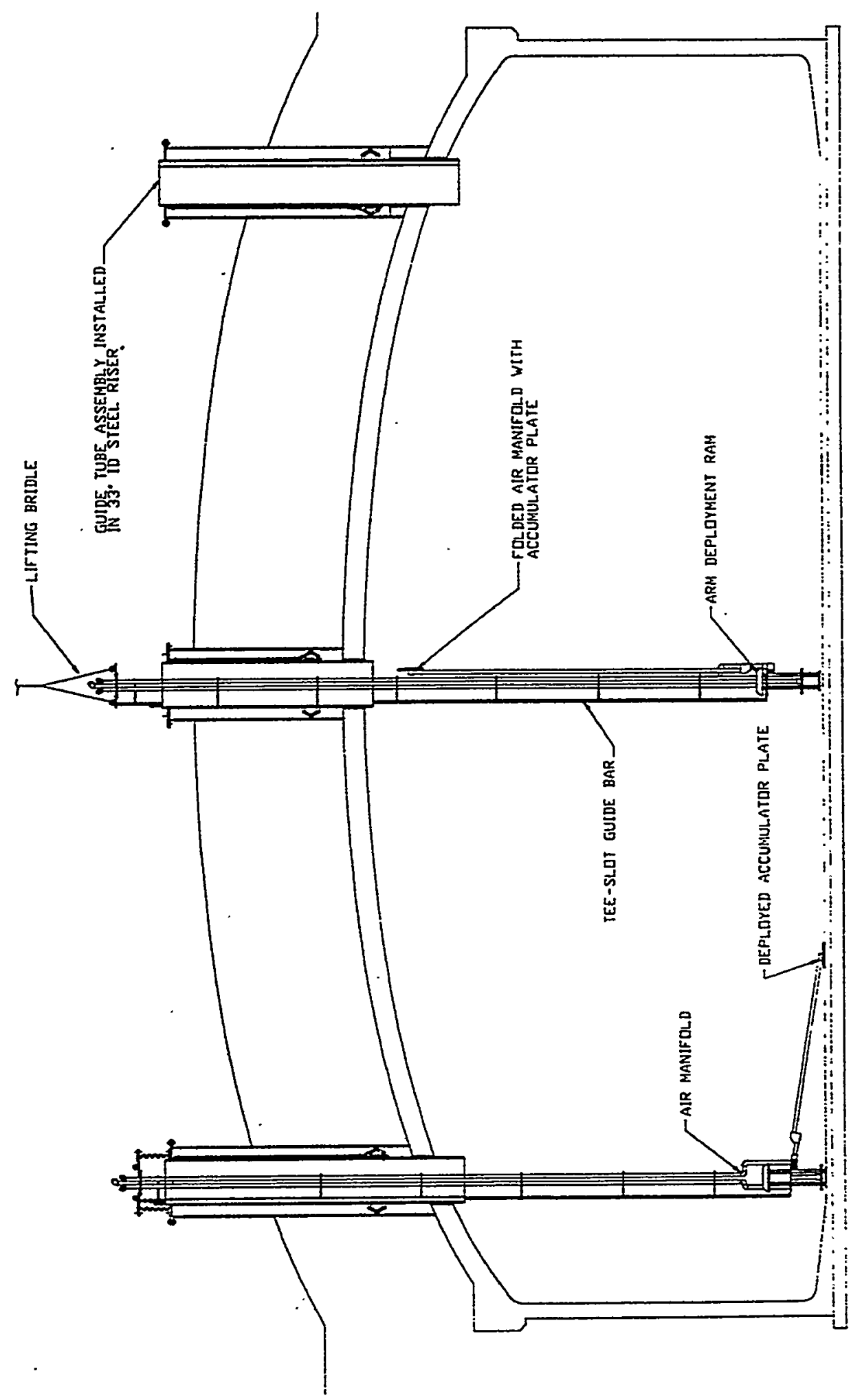

Figure 6.9 Multiple mixer plates deployed via the inverted umbrella approach 


\subsubsection{Pulsed-Air Mixer Operating Experience and Performance}

In 1999, a pulsed-air mixer array installed in ORNL Tank W-9 was operated to mix the tank contents. Upon resuspension, the slurry was recirculated through a slurry monitoring test system to evaluate the slurry transport properties. The pulsed-air system was installed as three separate assemblies with a total of 13 accumulator plates.

Four pulsed-air system parameters were evaluated during the demonstration: dwell time, the time between air injections $(10,14,18 \mathrm{~s})$; injection time, the amount of time air is injected through a pulse plate (1 s); air supply pressure [0.24 MPa (35 psig)]; and recirculation pump elevation from the tank floor [1.2 to $1.8 \mathrm{~m} \mathrm{(} 4$ and $6 \mathrm{ft}$ )]. Test results show that the mixing time was dependent upon dwell time. The shorter dwell time mixed the tank more quickly. Also the equilibrium condition obtained in the tank was dependent upon the elevation of the retrieval pump. The highest concentration, $3.1 \mathrm{wt} \%$ solids, was

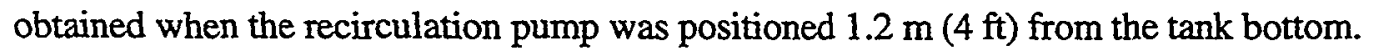

\subsubsection{Pulsed-Air Mixer Deployment for Enhanced Sludge Removal}

The pulsed-air mixer plate diameter selected for deployment at ORNL was $27.9 \mathrm{~cm}$ (11 in.). The plate area must be reduced by a factor of 3.4 to provide a system that could be deployed through a 15.2cm- (6-in.) diameter riser.

In addition, the system only has been tested with kaolin clay slurries, not with sludges with measurable shear strengths. If the deployment issue is addressed, tests with a waste simulant with a shear strength in the range of the required $1.96 \mathrm{kPa}\left(41 \mathrm{lbf} / \mathrm{ft}^{2}\right)$ must be evaluated to determine the extent of resuspension.

\subsection{Waste-Retrieval End Effector}

In 1997, ORNL selected a lightweight scarifying end effector, a jet-pump conveyance system, and two deployment systems: the light duty utility arm (LDUA) and the Houdini remotely operated vehicle (ROV) to perform the Gunite and associated tanks treatability study (GAAT-TS). Two scarifier end effectors were evaluated: the sludge retrieval end effector (SREE) optimized for sludge retrieval and the gunite scarifying end effector (GSEE) optimized for scarification of gunite surfaces. These are both variations of the confined-sluicing end effector (CSEE). Diagrams of the sludge retrieval end effector and the gunite scarifying end effector are shown in Figures 6.10 and 6.11. 


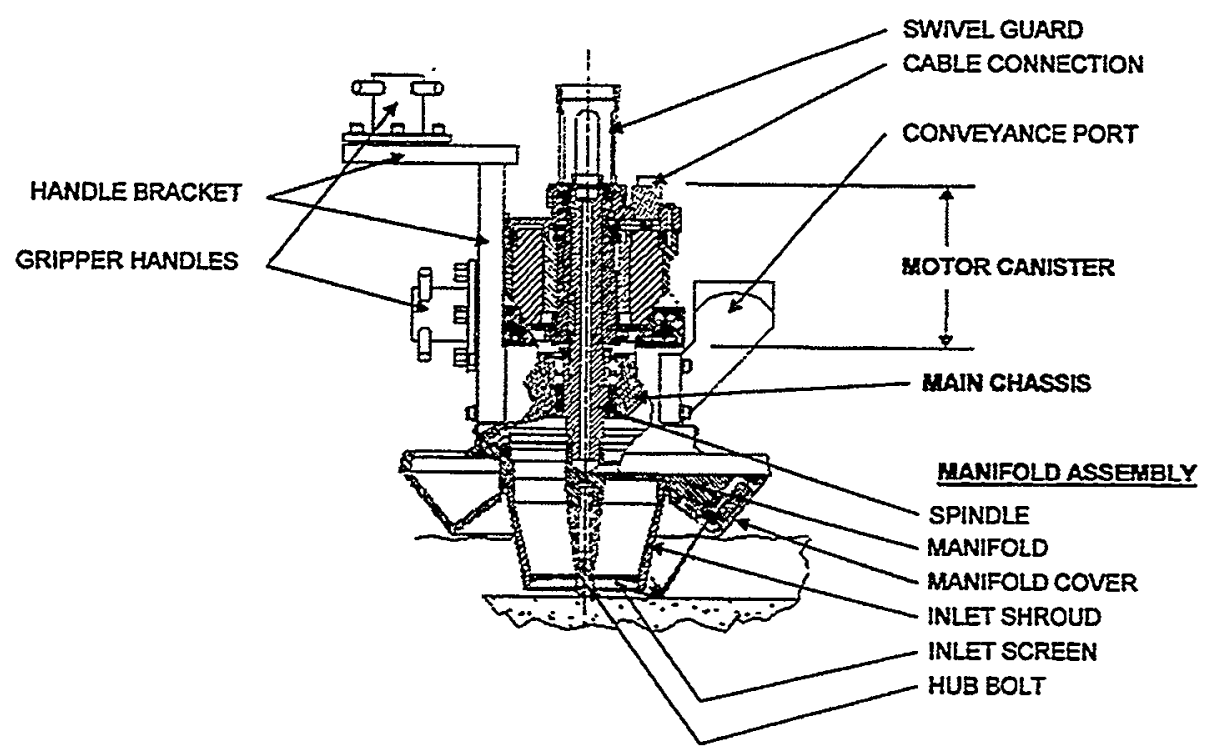

Figure 6.10 Sludge retrieval end effector

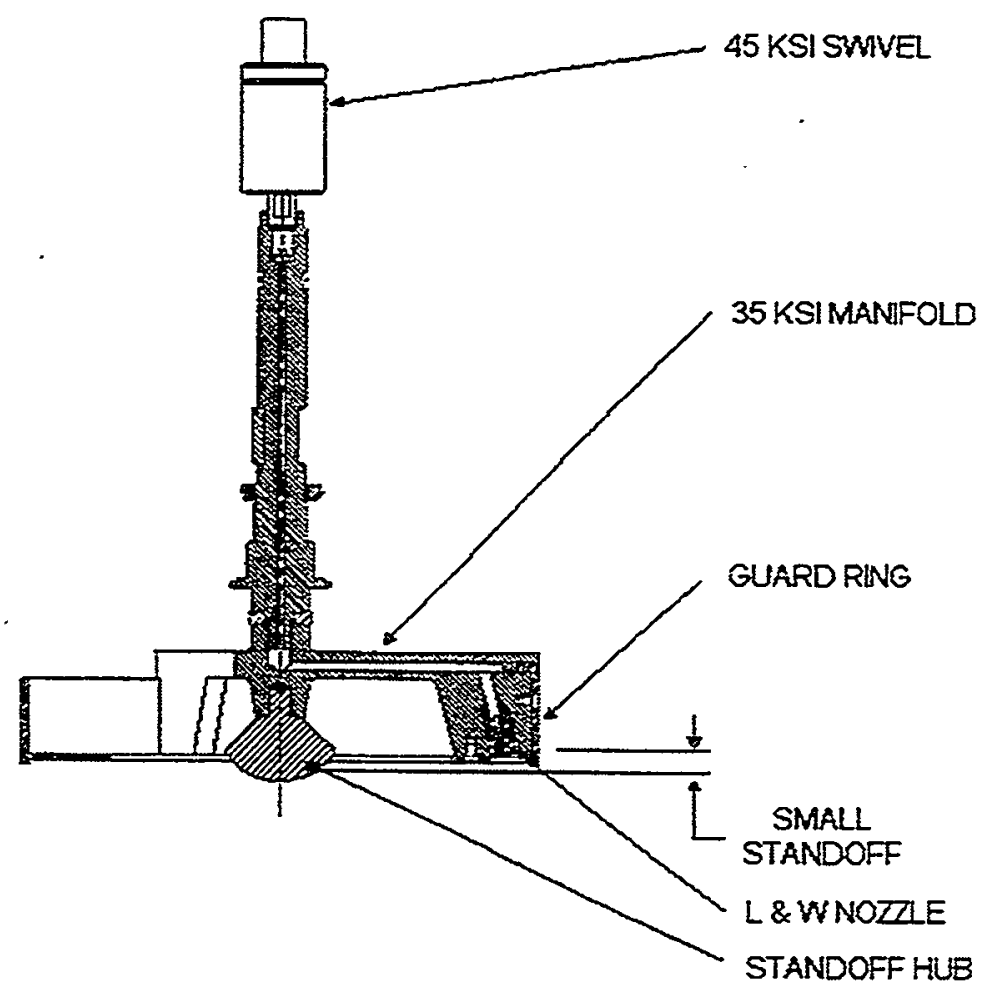

Figure 6.11 Gunite scarifying end effector 


\subsubsection{Waste Retrieval End-effector Operation}

Scarifying end effectors employ a rotating array of small water jets to fragment and dislodge waste. The jet nozzles are arrayed on a manifold, which rotates about an axis normal to the waste surface. The jet size and pressure, rotational frequency, and traverse speed are tailored to the properties of the waste. The end effector was approximately $38.1 \mathrm{~cm}$ (15 in.) in diameter and was deployed through a 53.3-cm(21-in.-) diameter riser. The sludge retrieval end effector operated at pressures from 2.07 to $69 \mathrm{MPa}$ (300 to $10,000 \mathrm{psi}$ ), and the gunite scarifying end effector operated at pressures from 2.07 to $207 \mathrm{MPa}$ (300 to $30,000 \mathrm{psi})$. The flow rate per jet was variable up to $0.0063 \mathrm{~m}^{3} / \mathrm{s}(10 \mathrm{gal} / \mathrm{min})$.

\subsubsection{Waste-Retrieval End-Effector System Components}

The end-effector system includes the end effector, the deployment mechanism - either a remote vehicle or an arm-based deployment system, the pump to supply pressurized water to the end effector and the conveyance system.

\subsubsection{Waste-Retrieval End-Effector Performance}

The sludge retrieval end effector was deployed in ORNL Gunite Tank W-3. The waste depth was estimated to be $0.6 \mathrm{~m} \mathrm{(} 2 \mathrm{ft}$ ) after the supernatant was removed. The waste was stratified in irregular layers; some appeared to be fairly solid or elastic, like damp chalk or gypsum; other layers were more viscous. A rough estimate of sludge properties was made based on video tape records. The larger pieces of sludge appeared similar in strength to a bentonite-water slurry in the 15 to $20 \mathrm{wt} \%$ solids range. The shear strength of such a mixture is between 0.1 and $1.5 \mathrm{kPa}\left(2.1\right.$ to $\left.31 \mathrm{lbf} / \mathrm{ft}^{2}\right)$.

To remove waste from Tank W-3, operators held the SREE 0.3 to $0.6 \mathrm{~m}$ ( 1 to $2 \mathrm{ft}$ ) away from the surface and operated the SREE at 6.9 to $27.6 \mathrm{MPa}(1000$ to $4000 \mathrm{psi})$ at $200 \mathrm{rpm}$ to slurry the waste. Then they lowered the SREE into the slurry with jets and rotation still on to pump it out with the conveyance pump.

Severe mixing and occlusion of visibility occur while scarifying with the SREE because the conveyance system doesn't move enough air to capture ejecta and spray for the jets scattered by the irregular concrete surface and there is no shroud to confine the spray to the immediate area.

During clean out of Tank W-3, the SREE used $21.4 \mathrm{~m}^{3}$ (5658 gal) of water to dislodge $41.7 \mathrm{~m}^{3}$ (11,014 gal) of waste. An additional $53.2 \mathrm{~m}^{3}$ (14,063 gal) of water was used by the jet pump conveyance system. Additional information is provided in Rule et al. (1998). 


\subsubsection{Waste-Retrieval End-Effector Deployment for Enhanced Sludge Removal}

The waste-retrieval end effector has the ability to dislodge sludge and waste with high shear strengths, so it is well suited to dislodge the waste piles. However, the system would require a complete redesign to engineer a system to be deployed through a 15.2-cm- (6-in.-) diameter riser. Also, significant ancillary equipment to deploy the end effector either via remote vehicle or arm-based deployment is required.

\subsection{Pulsating Mixer Pump}

In 1999, pulsating mixer technology, consisting of a jet mixer powered by a reciprocating air supply, was selected for deployment in Oak Ridge National Laboratory Tank TH-4 to mobilize settled solids. The pulsating mixer technology was identified as a promising technology that could be implemented in the DOE complex, during FY 1996 and FY 1997 technical exchanges between the US Department of Energy Tanks Focus Area Retrieval and Closure program, the DOE Environmental Management International Programs, and delegates from Russia. The pulsating mixer technology, provided by the Russian Integrated Mining Chemical Company, was tested at Pacific Northwest National Laboratory to observe its ability to suspend settled solids. Based on the results of this demonstration, ORNL and DOE staff determined that a modified pulsating mixer would meet project needs for bulk mobilization of gunite tank sludge prior to deployment of other retrieval systems. This deployment is expected to save the costs associated with operation and maintenance of more expensive retrieval systems.

\subsubsection{Pulsating Mixer Pump Components and Operation}

The original pulsating mixer pump, shown in Figure 6.12, consists of an upright cylindrical reservoir, a foot check valve, a working-gas supply pipe, a discharge manifold, and jet nozzles. The gas supply pipe is plumbed to a control valve, which alternates the exposure of the line between a vacuum and air supply source. In operation, the waste is drawn into the reservoir through the foot check valve when the supply pipe is valved to the vacuum source. The supply pipe is then pressurized with supply air; the pressurized air discharges the fluid out of the monitor reservoir back into the tank through the jet nozzles.

\subsubsection{Pulsating Mixer Pump Evaluation at PNNL}

Only two jet nozzles were used during testing at PNNL; however, there are four ports for jets in the head. The preliminary drawings showed a fifth nozzle directed axially downward on the centerline of the monitor, but the port for that jet was not present on the test article.

The vacuum supply to the pulsating equipment was provided by an axial-jet eductor furnished with the equipment. A diesel-powered trailer compressor supplied compressed air to the pulsating monitor and the vacuum eductor. The eductor was supplied and specified by.Integrated Mining Chemical Company as requiring $4 \mathrm{~m}^{3} / \mathrm{min}(141 \mathrm{cfm})$ of air delivered at approximately $0.48 \mathrm{MPa}$ gauge $(70 \mathrm{psig})$ to produce 0.40 
MPa gauge (5.8 psig) of vacuum. The air supply line to the eductor was operated at a pressure of $725 \mathrm{kPa}$ gauge (105 psig) and was throttled to obtain the desired vacuum line pressure. The actual air flow rate to the eductor was not measured.

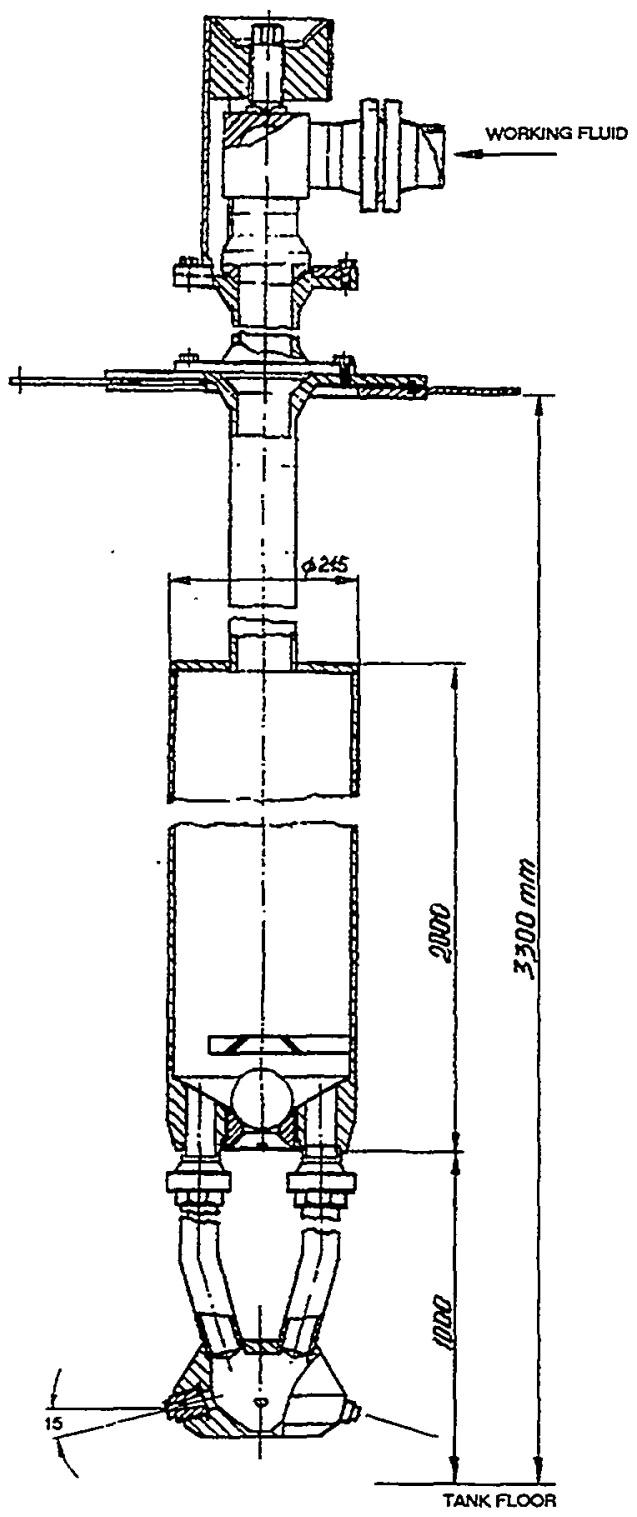

Figure 6.12 Pulsating monitor system tested at PNNL

At PNNL, the operation of the pulsating mixer pump was demonstrated in a 5.7-m- (18.75-ft-) diameter tank. The pulsating mixer pump operation was visualized using medium grain sand [ 1 to 2.4 $\mathrm{mm}(0.004$ to $0.1 \mathrm{in}$.)] spread over the tank bottom and water as a supernatant liquid. The size of the sand was selected to be large enough so that the pulsating mixer pump jets would not suspend the sand when 
the system was operating at the control settings selected for the demonstration. The purpose of the sand was to provide flow visualization of the influence that the pulsating mixer pump jets have on the test tank floor. The pulsating mixer pump contained two diametrically opposed, 8-mm- (0.31-in.-) diameter nozzles. Two tests, Tests 3 and 4, were conducted with the pulsating mixer pump remaining stationary (not rotating).

Test 3 was conducted with the nozzles oriented in a north-south direction. During Test 3, the period was $21 \mathrm{~s}$, and the vacuum and supply pressures were $77 \mathrm{kPa}$ absolute (11.1 psia) and $557 \mathrm{kPa}$ gauge (80.7 psig), respectively. The pulsating mixer pump was run for 9 min.; then the cleared area on the tank floor was measured. The dimensions for the observed area of jet influence on the bottom of the tank are presented in Figure 6.13. The pulsating mixer pump was not located in the center of the tank.

The first jet pulse cleared the floor of sand out to a distance of approximately $1.5 \mathrm{~m}(5 \mathrm{ft})$ and on the second pulse to about $1.8 \mathrm{~m}$ (6 ft). After the first four pulses, the growth of the footprint slowed considerably. After $9 \mathrm{~min}$. of operation, the jets were still moving sand on the bottom of the tank causing the cleared area to grow at a slow rate.

For Test 4 , the pulsating mixer pump was rotated $90 \mathrm{deg}$ to orient one of the nozzles to erode a thick layer of sand. The pulse rate was maintained at $21 \mathrm{~s}$, and the time average pressures were $78 \mathrm{kPa}$ absolute (11.4 psia) and $556 \mathrm{kPa}$ gauge (80.7 psig) for the vacuum and supply pressure, respectively. Test 4 was run for approximately $4 \mathrm{~min}$. The dimensions for the cleared area created by the jet to the west of the pulsating mixer pump (i.e., through the thick layer of sand) are presented in Figure 6.13.

\subsubsection{Control System Planned for Use at ORNL}

The primary functions of the control system are: 1) to permit the pulsating mixer pump system to operate optimally over a range of operating conditions; 2) to provide automatic shut down in case an outof-specification condition occurs; and 3) to allow remote operation of the system from either the inside of the ORNL Gunite Tank Farm control shed, which has a maximum distance from the tank risers of $91 \mathrm{~m}$ ( $300 \mathrm{ft}$ ), for the riser site. Under steady-state operating conditions, the pulsating mixer pump should require minimal manual intervention. However, if changes do occur in the operating conditions (e.g., changes in the height of the tank fluid, in the concentration of the tank slurry, or fouling of the check valves or nozzles), adjustments must be made to rebalance the system. If the changes are a continual occurrence, continual or periodic action will be required. The system operation relies on the fill and evacuation phases of the pump cycle being balanced with regards to the flow rate. What is drawn into the reservoir must be discharged. If the system is out of balance, the volume of fluid in the reservoir will either incrementally decrease, eventually resulting in the discharging of air to the tank, or incrementally increase, resulting in fluid being drawn into the vacuum line.

The instrumentation will include sensors to measure liquid level in the pump chamber, chamber pressure, supply air pressure, and flush water pressure to allow the system to be remotely monitored. The process data will be displayed on a graphical user interface and allow the operator to view time-cyclic data. The control system will allow the operation to open and close valves individually; configure valves for standard and back-flush operations; adjust mixer rotational speed; and adjust intake and exhaust 
duration, pump pressure, and slurry exhaust rate. Data will be monitored by the control program to recognize indications of system degradation, such as an increase in cycle time.

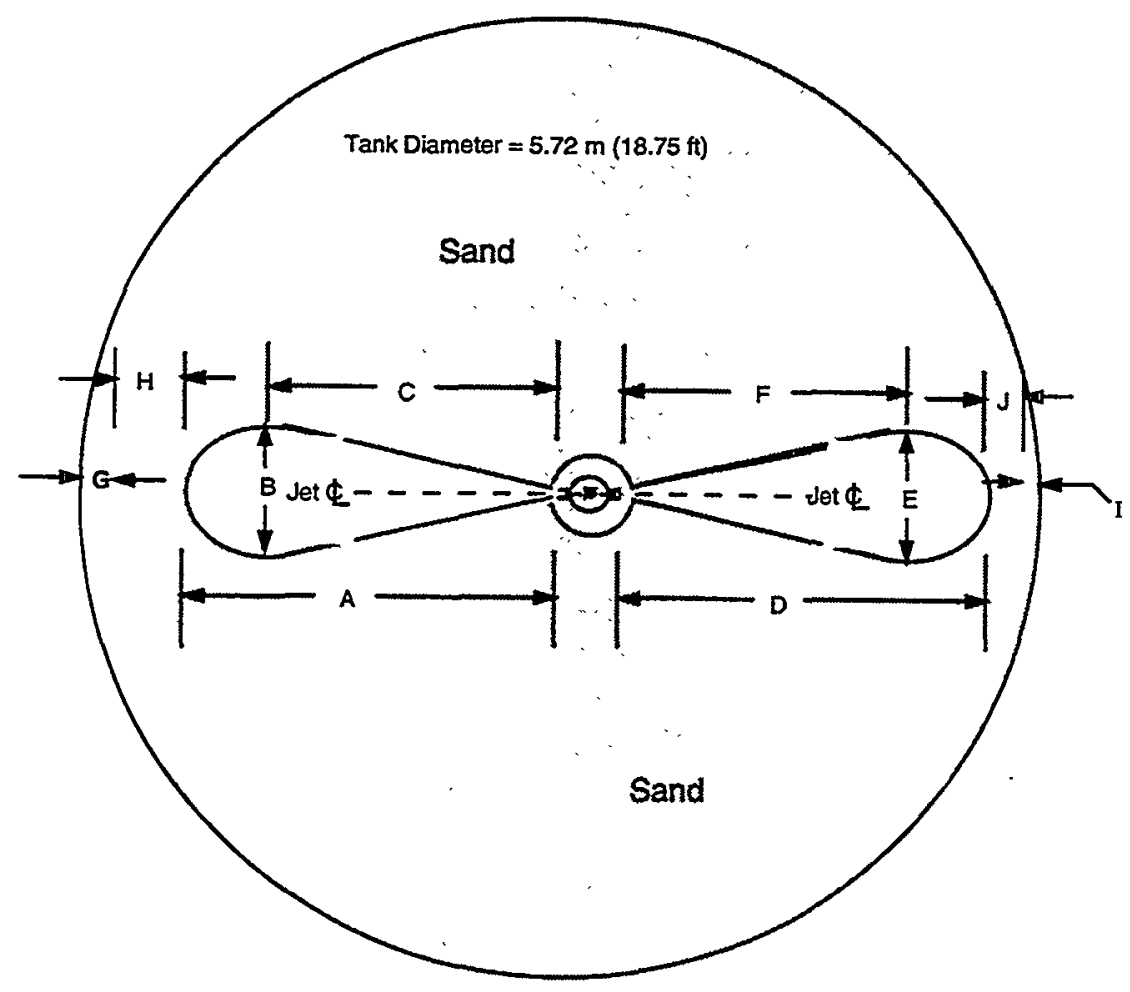

Test 3 Results

\begin{tabular}{|l|l|c|l|l|l|}
\hline Dimension & $\mathbf{m}$ & in. & Dimension & $\mathbf{m}$ & in. \\
\hline A & 2.34 & 92 & F & 1.6 to 1.7 & 63 to 66 \\
\hline B & 0.79 to .81 & $31-32$ & G & 0.20 & 8 \\
\hline C & 1.57 to 1.60 & $62-63$ & H & 0.25 & 10 \\
\hline D & 2.59 & 102 & I & 0.08 & 3 \\
\hline E & 0.76 to 0.79 & $30-31$ & J & 0.08 & 3 \\
\hline
\end{tabular}

Test 4 Results

\begin{tabular}{|l|l|l|l|l|l|}
\hline Dimension & \multicolumn{1}{|c|}{$\mathbf{m}$} & \multicolumn{1}{|c|}{ in. } & Dimension & $\mathbf{m}$ & in. \\
\hline A & 2.51 & 99 & H & 0.08 & 3 \\
\hline B & 0.60 & 24 & G & 0.08 & 3 \\
\hline C & $\begin{array}{l}1.78 \text { to } \\
1.83\end{array}$ & 70 to 72 & & & \\
& & & & \\
\hline
\end{tabular}

Figure 6.13 Diagram and dimensions of jet footprint created by pulsating mixer on tank floor. 


\section{Demonstrated Technologies for Enhanced Sludge Removal}

The applicability of many technologies has been evaluated for deployment at Hanford or other US Department of Energy sites. To provide some consistency between tests, many investigators used standardized simulant recipes for wet sludge, hardpan sludge, and saltcake wastes. Powell (1996) and Powell et al. (1997) describe the simulant recipes and physical and rheological characterization. The technologies that have been evaluated using specified simulants are described in this section. These technologies may not be as mature as the technologies described in Section 6 that have already been deployed for radioactive waste remediation.

Several of these technologies were evaluated through the Hanford Tanks Initiative project. The purpose of this project was to evaluate commercial technologies for potential deployment for waste remediation.

\subsection{High-Pressure Scarifier}

A high-pressure scarifier rated to remove $0.0009 \mathrm{~m}^{3} / \mathrm{s}\left(2 \mathrm{ft}^{3} / \mathrm{min}\right)$ of waste was initially developed for retrieval of hard single-shell tank salt cake waste (Bamberger et al. 1993a, b and 1994) with no significant accumulation of fluid within the tank. This system used high pressure $[379 \mathrm{MPa}(55,000 \mathrm{psi})]$ jets and air conveyance to dislodge and retrieve waste. The system performed well; however, Hanford Site deployment needs changed and a lightweight version of the scarifier, shown in Figure 7.1, was designed and tested.
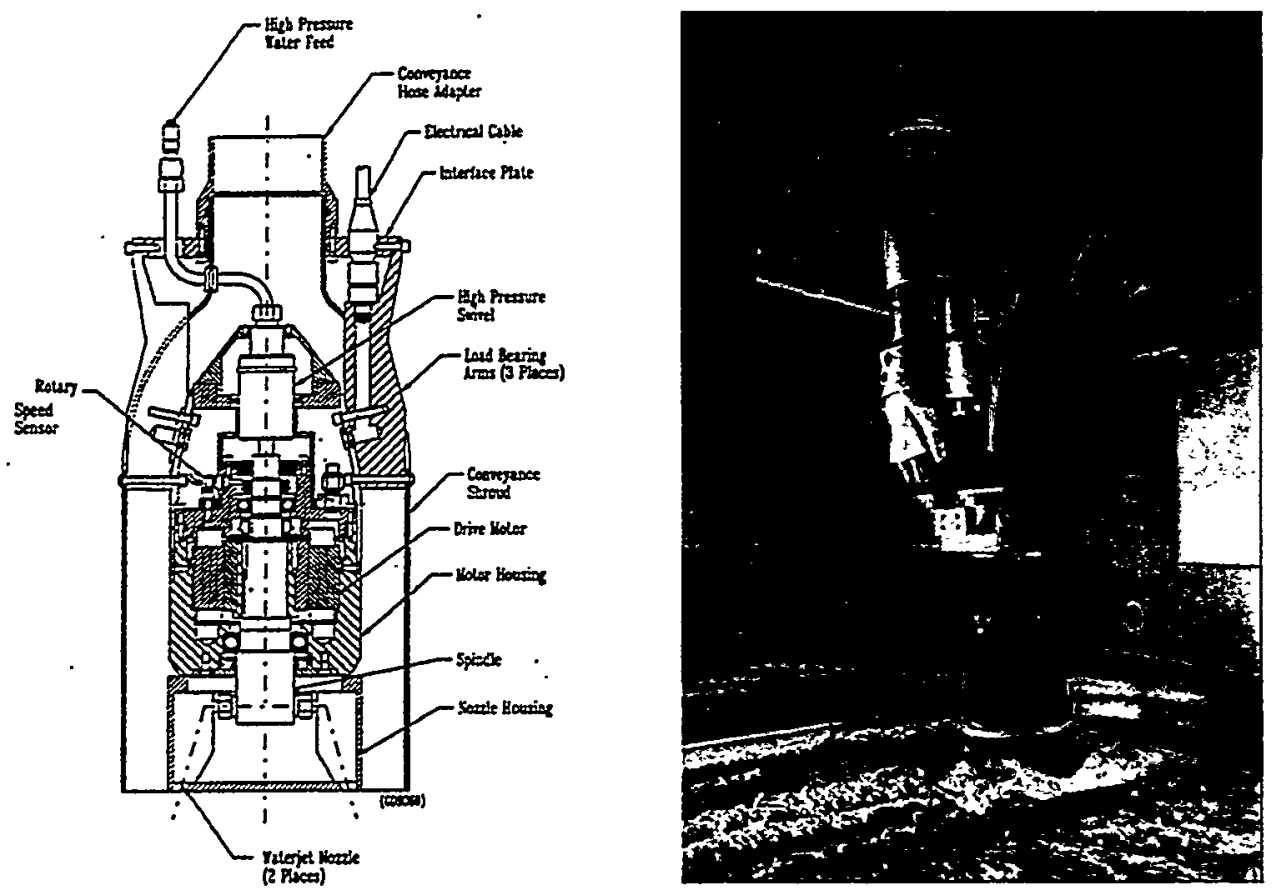

Figure 7.1 Lightweight scarifier deployed by light duty utility arm dislodging salt-cake simulant 
The lightweight scarifier uses two ultra-high-pressure water jets to fracture and dislodge waste. The waterjets require $0.00038 \mathrm{~m}^{3} / \mathrm{s}(6 \mathrm{gal} / \mathrm{min})$ of water at up to $345 \mathrm{MPa}(50,000 \mathrm{psi})$. The jet manifolds rotates between 0 and $1000 \mathrm{rpm}$. The motor that controls rotation is mounted concentric to and inside the annular conveyance inlet shroud. The scarifier weighs approximately $22.7 \mathrm{~kg}(50 \mathrm{lbm})$, is $25.4 \mathrm{~cm}(10$ in.) diameter, and 48.3 (19 in.) high (Hatchell 1997).

The lightweight scarifier was deployed with the EMMA robotic manipulator to evaluate the system's ability to dislodge salt cake and dried sludge waste simulants (Grey Pilgrim 1997).

\subsection{Advanced Sluicing System}

Los Alamos Technical Associates, Inc. (1997) tested sluicer nozzle performance. Two nozzle configurations were evaluated to determine their ability to erode salt cake and hard pan waste simulants. The nozzles tested had bores of 2.54 and $3.175 \mathrm{~cm}$ ( 1 and $1.25 \mathrm{in}$.). The nozzles were tested at stand-off distances of $\sim 5.2 \mathrm{~m}(\sim 17 \mathrm{ft})$. Against the hardest salt cake waste simulant $\left[20.7 \mathrm{MPa}\left(432005 \mathrm{lbf} / \mathrm{ft}^{2}\right)\right.$ compressive strength] sluicing was able to dislodge waste at rates greater than $1.4 \times 10^{-4} \mathrm{~m}^{3} / \mathrm{s}(0.29$ $\left.\mathrm{ft}^{3} / \mathrm{min}\right)$. For hard pan simulant $\left[32 \mathrm{kPa}\left(662 \mathrm{lbf} / \mathrm{ft}^{2}\right)\right]$ removal rates were $\left.3.9 \times 10^{-4} \mathrm{~m}^{3} / \mathrm{s}\left(0.82 \mathrm{ft}^{3} / \mathrm{min}\right)\right]$ using the $3.175 \mathrm{~cm}\left(1.25 \mathrm{in}\right.$.) nozzle, and for another hard pan simulant [ $\left.150 \mathrm{kPa}\left(3139 \mathrm{lbf} / \mathrm{ft}^{2}\right)\right]$ removal rates were $1.2 \times 10^{-5} \mathrm{~m}^{3} / \mathrm{s}\left(0.025 \mathrm{ft}^{3} / \mathrm{min}\right)$ using the $2.54-\mathrm{cm}(1$-in. $)$ nozzle.

\subsection{Vehicle Deployed Sluicer}

Ard Environmental (1996, 1997a, b) tested a self-propelled robotic crawler vehicle that deployed various tools including a rotating cutter, scabbler, and hydraulic jack hammer to evaluate the ability of the combination to dislodge wet sludge, saltcake, and dried hardpan waste simulants.

The hydraulically driven vehicle, shown in Figure 7.2, weighed $907 \mathrm{~kg}(2000 \mathrm{lbm})$ and provided 6508 $\mathrm{N}$-m (4800 ft-lbf) of torque. The sluicer was equipped with 14 sluicing nozzles with a diameter of 0.128 in. and a 0 deg spray angle. The operating flow rate was 0.0072 to $0.0077 \mathrm{~m}^{3} / \mathrm{s}$ (114 to $\left.122 \mathrm{gal} / \mathrm{min}\right)$ at 2.8 to $3.1 \mathrm{MPa}$ ( 400 to $450 \mathrm{psi}$ ). The sluicer eductor, located in the center of the sluicing nozzles, had a suction capacity of $0.0063 \mathrm{~m}^{3} / \mathrm{s}$ (100 gal/min). 

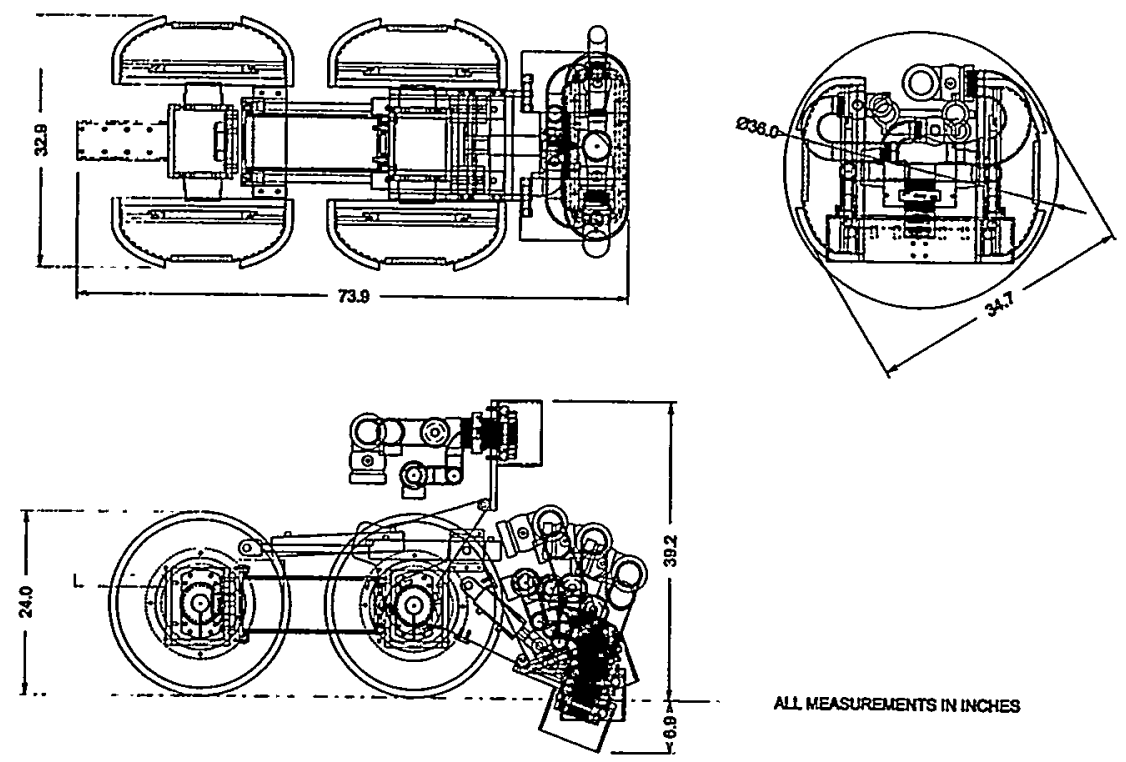

ALL MEASUREUENTS IN INCHES

Figure 7.2 Vehicle with sluicer attachment

\subsection{Flygt Mixers}

Axial shrouded-propeller mixers developed by ITT Flygt Corporation ${ }^{1}$ are being evaluated for deployment in Savannah River Site Tank 19 to resuspend sludge, zeolite, and salt that remain in the tank after a retrieval campaign conducted in the early 1980s (Powell et al. 1999a, b, c). During this campaign two jet mixer pumps were used to dissolve and retrieve the salt cake. This technology may also be applicable for deployment at Hanford.

Flygt mixers consist of an electrically-powered propeller surrounded by a close-fitting shroud. Specially sized mixers were designed for deployment in Tank 19 . These $37-\mathrm{kW}$ (50 hp) mixers being considered for use in Tank 19 have a propeller diameter of $51 \mathrm{~cm}(20 \mathrm{in}$.) and operate at $860 \mathrm{rpm}$. The spinning propeller creates a turbulent fluid jet with an average exit velocity of $5.4 \mathrm{~m} / \mathrm{s}(17.7 \mathrm{ft} / \mathrm{s})$. The mixers are shown in Figure 7.3. The mixers were modified to include a wire-mesh screen to protect the propeller from in-tank debris. With the inlet screen installed and the mixer operating at full speed, the mixer is expected to generate a water flow rate of about $1.1 \mathrm{~m}^{3} / \mathrm{s}(17,500 \mathrm{gal} / \mathrm{min})$. This flow rate corresponds to a mixer thrust of $6160 \mathrm{~N}$ (1385 lbf) and a hydraulic power of $30 \mathrm{~kW}(40 \mathrm{hp})$. Four mixers were procured for eventual installation in Tank 19.

A series of scaled tests were conducted to evaluate the Flygt mixers. Key findings show that fluid velocities in the 30 to $50 \mathrm{~cm} / \mathrm{s}(0.98$ to $1.6 \mathrm{ft} / \mathrm{s})$ range are required to maintain $20 \times 50$-mesh zeolite particles suspended in water. For all particles to remain in suspension, the average fluid velocity $5 \mathrm{~cm} \mathrm{(2}$ in.) above the tank floor must exceed $50 \mathrm{~cm} / \mathrm{s}(1.6 \mathrm{ft} / \mathrm{s})$ in all locations. Measurements to date made at full scale confirm scaled predictions that three fixed position Model 4680 Flygt mixers do not provide

\footnotetext{
${ }^{1}$ Trumbull, Connecticut.
} 
sufficient mixing intensity to achieve the required fluid velocities near the tank floor in all regions of the tank to keep zeolite in suspension.

No data for the shear strength of the Tank 19 heel were available. Scaled Flygt mixer tests in a 0.45$\mathrm{m}$ - (1.5-ft-) diameter tank were conducted using kaolin clay in water with a shear strength of $0.4 \mathrm{kPa}(8.4$ $\left.\mathrm{lbf} / \mathrm{ft}^{2}\right)$. Recommendations have been made to test the full-scale mixers in the $5.7-\mathrm{m}$ - (18.75-ft-) diameter tank with this simulant.

Prior to selection for enhanced sludge mobilization at Hanford, the ability of the mixers to mobilize simulants with shear strengths in the required range must be established as must the ability to provide mobilization over the range of effective cleaning radius. Also, the system designed for Savannah River Site could only be deployed through a 0.61 - or 1.1-m- (24- or 42-in.-) diameter riser.
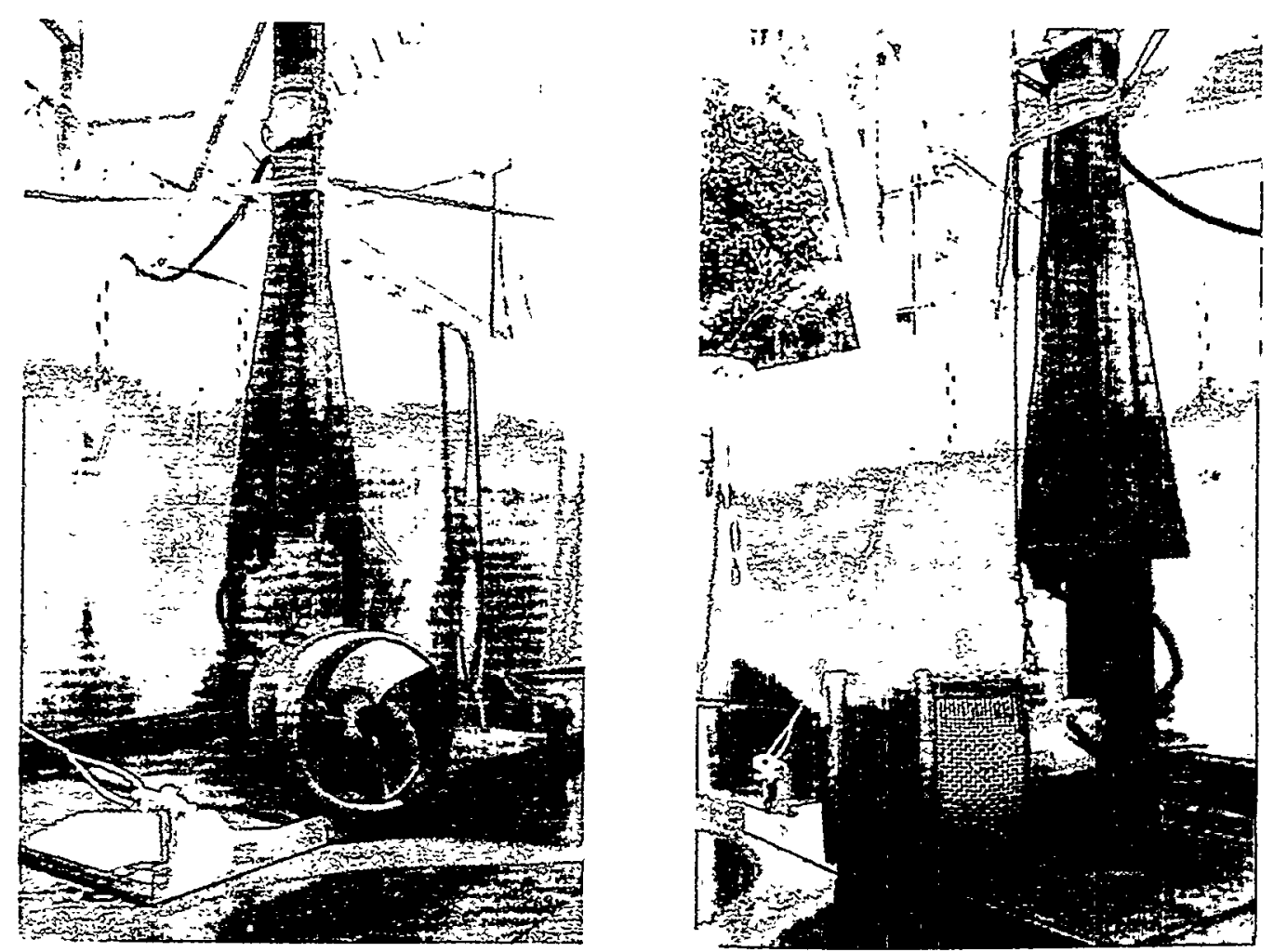

Figure 7.3 Modified Flygt mixers constructed for Tank 19 


\section{Industrial Technologies for Enhanced Sludge Removal}

For many years researchers at Hanford and other DOE sites have addressed the need to identify new technologies for tank waste mobilization, retrieval, and tank remediation. The problem of enhanced sludge retrieval from areas of accumulation out of the range of mixer-pump technologies permits evaluation of prior studies and new technologies with this different emphasis. Two industrial applications of tank cleaning technology include cleaning of vessel hulls and train tank cars. These areas were evaluated to determine whether any of the equipment could be deployed for tank applications.

\subsection{Literature Survey of Mixing Techniques for Double-Shell Tanks}

In 1997 a literature search was conducted to identify commercially available applicable mixing technologies that could be used for double-shell tank sludge mobilization and mixing (Daymo 1997). The report summarized the advantages and disadvantages of tank mixing technologies including jet mixer pumps, agitator-based systems, pulsed-air, sluicing, pulsed-jet mixers, air-lift circulators, and other novel methods such as arm-based or crawler-based retrieval methods, wave machines, sonic probes, bullets, positive displacement pumps, and solution mining.

In addition a literature survey of mixing technology was conducted. This survey included evaluation of: previous searches for alternate double-shell tank mixing technologies in the DOE complex, research articles in trade publications, internet search, conferences, classes, the Thomas Register, and conduction of discussions with leading mixing consultants. The literature search did not reveal any previously unknown technologies that should be considered for sludge mobilization and mixing in $3785 \mathrm{~m}^{3}$ (milliongallon) double-shell tanks.

\subsection{Consilium Gun Clean}

Consilium Gunclean ${ }^{1}$ developed single-nozzle tank cleaning machines for use in vessel holds below deck. The nozzle performs a slow horizontal rotation combined with an even slower vertical oscillation resulting in a helical cleaning pattern. Systems have been designed that use either water or crude oil as the cleaning fluid. The systems are specially designed to meet the requirements of onboard product/chemical tankers. In these cases, hazardous and toxic vapors are generated by the cargo; therefore, cleaning operations must be conducted under closed conditions. The system is also configured to permit cleaning at several levels with synchronized nozzle motions to reach areas that are obstructed by hardware. Systems are available with custom designed nozzle levels for these types of cleaning applications.

1 Consilium. 1999. Gunclean Tank and Hold Cleaning Systems, http://www.consilium.se/MarineGroup/gunclean.htm USA Consilium Metritape, 59 Porter Road, P.O. Box 2366, Littleton, MA 01460, Phone: +1-978-486 9800, Telex: +1-978-486 0170, Telex: 923-492USA. 
The nozzles could be configured to fit through a 15.2-cm- (6-in-) diameter riser. Also operating pressures could be selected to permit sludge mobilization.
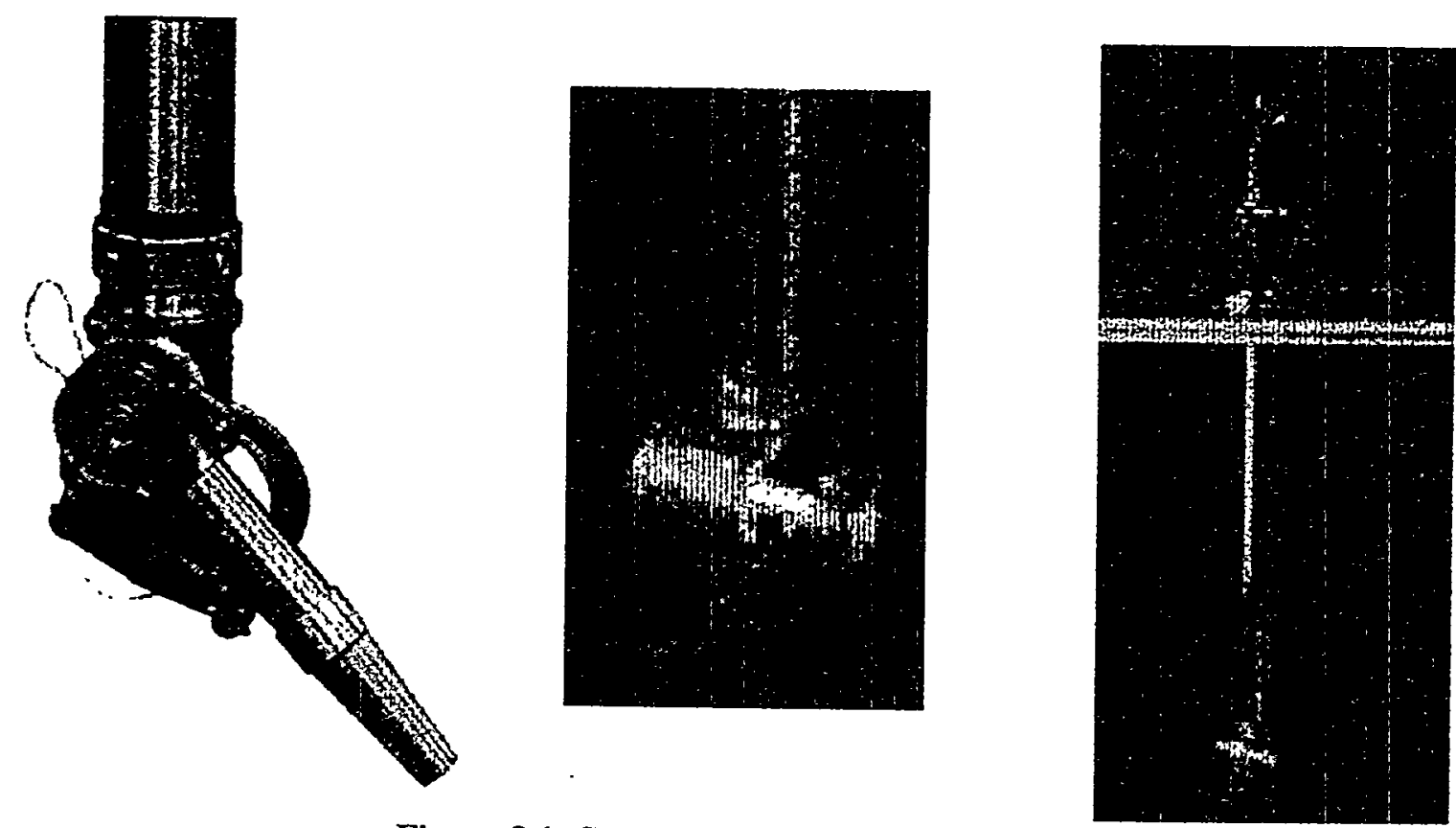

Figure 8.1 Gunclean nozzle configurations 


\section{References}

ARD Environmental, Inc. 1996. Testing of Scavenger Systems Dislodging \& Conveyance Devices. WHC-SD-WM-TD-011, Rev. 0A. Prepared by ARD Environmental, Inc., Laurel, Maryland for Westinghouse Hanford Company, Richland, Washington.

ARD Environmental, Inc. 1997a. Alternate Retrieval Technology Demonstrations Program - Test Report. HNF-MR-0542, Rev. 0. Prepared for Lockheed Martin Hanford Company, Richland, Washington by ARD Environmental, Inc. Laurel, Maryland.

ARD Environmental, Inc. 1997b. Task 5 Test Report: Demonstration of Low Pressure Confined Sluicer and Vehicles for SST Tank Waste Retrieval at Hanford. HNF-MR-0534, Rev. 0. Prepared by ARD Environmental, Inc., Laurel, Maryland for Lockheed Martin Hanford Company, Richland, Washington.

Bamberger, J.A. and D.E. Steele. 1993a. Developing a Scarifier to Retrieve Radioactive Waste from Hanford Single-Shell Tanks. PNL-SA-22721. In Proceedings of the 7th American Water Jet Conference, Vol II, Water Jet Technology Association. M Hashish, Ed. p.737-745.

Bamberger, J.A. and G.F. Boris. 1999a. Oak Ridge National Laboratory Old Hydrofracture Facility Waste Remediation Using the Borehole-Miner Extendible-Nozzle Sluicer. PNNL-12225, Pacific Northwest National Laboratory, Richland, Washington.

Bamberger, J.A. and M.W. Rinker. 1996. Waste Retrieval System Development and Demonstration. In Proceedings of the International topical Meeting on Nuclear and Hazardous Waste Management Spectrum 96. American Nuclear Society, Inc. La Grange Park, Ilinois. p 1921-1928.

Bamberger, J.A., D.G. Alberts, C.W. Enderlin, and M. White. 1998. Borehole Miner Extendible Nozzle Development for Radioactive Waste Dislodging and Retrieval from Underground Storage Tank. PNNL-11730, Pacific Northwest National Laboratory, Richland, Washington.

Bamberger, J.A., G.F. Boris, and D.G. Alberts. 1999b. Using the Borehole Miner Extendible-Nozzle Sluicing System to Dislodge and Mix Settled Sludge and Supernate in the Old Hydrofracture Tanks During Remediation at Oak Ridge National Laboratory, Oak Ridge, Tennessee. American Nuclear Society, Eighth International Topical Meeting Robotics and Remote Systems, April 25-29, 1999, Pittsburgh, Pennsylvania. American Nuclear Society Order No. 700271, La Grange Park, Ilinois.

Bamberger, J.A., J.M. Bates, J.K. Keska, M.R. Elmore, and N.J. Lombardo. 1993b. Strategy to Develop and Test a Multi-Function Scarifier End Effector with An Integral Conveyance System for Waste Tank Remediation. PNL-8477, Pacific Northwest Laboratory, Richland, Washington.

Bamberger, J.A., M.A. McKinnon, D.A. Alberts, D.E. Steele, and C.T. Crowe. 1994. Development of a Multi-Functional Scarifier Dislodger with an Integral Pneumatic Conveyance Retrieval System for Single-Shell Tank Remediation. PNL-8901, Pacific Northwest Laboratory, Richland, Washington. 
Brothers, A.J., N.C. Williams, J.S. Dukelow, R.I. Hansen, R.D. Claghorn, C.E. Grenard, and R.M. Marusich. 1997. Decision Analysis for Mobilizing and Retrieving Sludge from Double-Shell Tanks. PNNL-11718, Pacific Northwest National Laboratory, Richland, Washington.

Carothers, K.G., S.D. Estey, N.W. Kirch, L.A. Stauffer, and J.W. Bailey. 1999. Tank 241-C-106 Waste Retrieval Sluicing System Process Control Plan. HNF-SD-WM-PCP-013, Rev. 2, Lockheed Martin Hanford Corporation, Richland, Washington.

Claghorn, R.D. 1998. Estimated Dose to In-Tank Equipment: Phase 1 Waste Feed Delivery. HNF2004, Numatec Hanford Corporation, Richland, Washington.

Conrads, T.J. 1998. Natural Phenomena Hazards Hanford Site, Washington. WHC-SD-GN-ER-501, Rev. 1, Westinghouse Hanford Company, Richland, Washington.

Dahl, T.L., A.C. Lay, S.A. Taylor, and J.W. Moore. 1999. C-Tank Transfers Transuranic Sludge Removal from the C-1, C-2, and W-23 Waste Storage Tanks at Oak Ridge National Laboratory, Oak Ridge, Tennessee. BJC/OR-279, Bechtel Jacobs Company LLC, Oak Ridge, Tennessee.

Daymo, EA. 1997. Industrial Mixing Techniques for Hanford Double-Shell Tanks. PNNL-11725, Pacific Northwest National Laboratory, Richland, Washington.

Enderlin, C.W., O.D. Mullen, and G. Terrones. 1997. Performance Evaluation of the Quarter-Scale Russian Retrieval Equipment for the Removal of Hazardous Waste. PNNL-11740, Pacific Northwest National Laboratory, Richland, Washington.

Environmental Specialties Group, LLC. 1997. Hanford Tanks Initiative Vehicle-Based Waste Retrieval d Demonstration Report Phase II, Track 2. HNF-MR-0544, Rev. 0, Prepared for Lockheed Martin Hanford Company, Richland, Washington by Environmental Specialites Group, LLC, Tulsa, Oklahoma.

Evans, M.S. 1996. Issues Associated with Manipulator-Based Waste Retrieval from Hanford Underground Storage Tanks with a Preliminary Review of Commercial Concepts. WHC-SD-WMTA-181, Rev. OA, Westinghouse Hanford Company, Richland, Washington.

Graham, RE. 1996. Test Results for Robotic Manipulator EMMA. WHC-SD-WM-TD-012, Rev. OA. Prepared by Grey Pilgrim LLC, Gaithersburg, Maryland for Westinghouse Hanford Company, Richland, Washington.

Grey Pilgrim, LLC. 1997. Hanford Tanks Initiative Alternate Retrieval System Demonstrations - Final Report of Testing Performed by Grey Pilgrim LLC. HNF-MR-0545, Rev. 0, prepared for Lockheed Martin Hanford Company, Richland, Washington by Grey Pilgrim LLC, Gaithersburg, Maryland.

Hanlon, B.M., 1999, Waste Tank Summary Report for Month Ending October 31, 1999, HNF-EP-0182139, Lockheed Martin Hanford Corporation, Richland, Washington. 
Hatchell, B.K. 1997. Engineering Development of a Lightweight High-Pressure Scarifier for Tank

Waste Retrieval. PNNL-11736, Pacific Northwest National Laboratory, Richland, Washington.

Hylton, T.D. and C.K. Bayne. 1999. Testing of In-line Monitors and Pulsair Mixers with Radioactive Slurries. ORNL/TM-1999/111, Oak Ridge National Laboratory, Oak Ridge, Tennessee.

Julyk, L.J. 1997. Evaluation of the Effect of Project W-151 Mixer Pump Jets on In-Tank Equipment Considering Potential Sludge Buildup on Equipment in Waste Tank 241-AZ-101, Hanford Site, Richland. Fluor Daniel Northwest, Inc., Richland, Washington.

Kent, T.E., S.A. Taylor, J.W. Moore, J.L. Stellern, and K.M. Billingsley. 1998a. Demonstration of Fluidic Pulse Jet Mixing for a Horizontal Waste Storage Tank. ORNL/TM-13578, Oak Ridge National Laboratory, Oak Ridge, Tennessee.

Kent, T.E., T.D. Hylton, S.A. Taylor, and J.W. Moore. 1998b. Deployment of a Fluidic Pulse Jet Mixing System for Horizontal Waste Storage Tanks at Oak Ridge National Laboratory, Oak Ridge, Tennessee. BJC/OR-82, Bechtel Jacobs, Company LLC, Oak Ridge, Tennessee.

Kirkbride, R.A., G.K. Allen, P.J. Certa, A.F. Manuel, R.M. Orme, L.W. Shelton, E.J. Slaathaug, R.S. Wittman, and G.T. Maclean and D.L. Penwell (SESC), 1999, Tank Waste Remediation System Operation and Utilization Plan, HNF-SD-WM-SP-012, Rev. 1, Vol. I and II, Numatec Hanford Corporation, Richland, Washington.

LMHC. 1999a. Tank Waste Remediation System Technical Safety Requirements. HNF-SD-WM-TSR006, Rev. 1, Lockheed Martin Hanford Corporation, Richland, Washington.

Los Alamos Technical Associates, Inc. 1997. Advanced Sluicing System Test Report for Single Shell Tank Waste Retrieval Integrated Testing. HNF-MR-0539, Rev. 0, prepared for Westinghouse Hanford Company, Richland, Washington by Los Alamos Technical Associates, Inc., Richland, Washington.

Magnox Electric PLC. 1997. Results of the SNAKES Manipulator and ARD Sluicer Testing as part of Hanford Single Shell Tanks Waste Retrieval - Phase 1-ACTR Integrated Testing.. HNF-MR-0538, Rev. 0, prepared for Fluor Daniel Hanford, Richland, Washington by Magnox Electric plc, Berkeley, Glos, United Kingdom.

May, T.H. 1996. Tank 241-C-106 Waste Retrieval Sluicing System (WRSS) Operations Manual. WHCSD-W320-TI-004, Westinghouse Hanford Company, Richland, Washington.

MPW Industrial Services, Inc. 1995. Demonstration of Retrieval Methods for Westinghouse Hanford Corp. October 20, 1995. WHC-MR-0526, prepared by MPW Industrial Services, Inc. for Westinghouse Hanford Company, Richland, Washington. 
MPW Industrial Services, Inc. 1996. Demonstration of Retrieval Methods for Westinghouse Hanford Corp. Trial No.2 April 30; 1996. WHC-MR-0527, prepared by MPW Industrial Services, Inc. for Westinghouse Hanford Company, Richland, Washington.

Mullen, O.D. 1997. Engineering Development of Waste Retrieval End Effectors for the Oak Ridge Gunite Tanks. PNNL-11586, Pacific Northwest National Laboratory, Richland, Washington.

Mullen, O.D. 1997. Field Performance of the Waste Retrieval End Effectors in the Oak Ridge Gunite Tanks. PNNL-11688, Pacific Northwest National Laboratory, Richland, Washington.

Murray, P. and H. Peters. 1999. Emptying Of C-Tanks At Oak Ridge Reservation Utilizing Pulse Jet Mixing. American Nuclear Society, Eighth International Topical Meeting Robotics and Remote Systems, April 25-29, 1999, Pittsburgh, Pennsylvania. American Nuclear Society Order No. 700271, La Grange Park, Illinois.

Noorani, Y.G. and G.W. Ryan. 1997. Tank Waste Remediation System Bases for Interim Operation. HNF-SD-WM-BIO-001 Rev 0, Lockheed Martin Hanford Company, Richland, Washington.

Powell, M.R. 1996. Initial ACTR Retrieval Technology Evaluation Test Material Recommendations. PNNL-11021, Pacific Northwest National Laboratory, Richland, Washington.

Powell, M.R. 1997. Retrieval Process Development and Enhancements Pulsed-Air Mixing DOE Site Assessment. PNNL-11584, Pacific Northwest National Laboratory, Richland, Washington.

Powell, M.R and C.R Hymas. 1996. Retrieval Process Development and Enhancements FY96 PulsedAir Mixer Testing and Deployment Study. PNNL-11200, Pacific Northwest National Laboratory, Richland, Washington.

Powell, M.R., G.R. Golcar, and J.G.H. Geeting. 1997. Retrieval Process Development and Enhancements Waste simulant Compositions and Defensibility. PNNL-11685, Pacific Northwest National Laboratory, Richland, Washington.

Powell, M.R., J.R. Farmer, H. Gladki, B.K. Hatchell, M.R. Poirier, and P.O. Rodwell. 1999a. Evaluation of Flygt Mixers for Application in Savannah River Site Tank 19, Test Results from Phase A: SmallScale Testing at ITT Flygt. PNNL-12094, Pacific Northwest National Laboratory, Richland, Washington.

Powell, M.R., J.R. Farmer, H. Gladki, B.K. Hatchell, M.A. Johnson, M.R. Poirier, and P.O. Rodwell. 1999b. Evaluation of Flygt Mixers for Application in Savannah River Site Tank 19, Summary of Test Results from Phase A, B, and C Testing. PNNL-12168, Pacific Northwest National Laboratory, Richland, Washington.

Powell, M.R., W.H. Combs, J.R. Farmer, H. Gladki, M.A. Johnson, B.K. Hatchell, M.R. Poirier, and P.O. Rodwell. 1999c. Evaluation of Flygt Mixers for Application in Savannah River Site Tank 19, Test 
Results from Phase B: Mid-Scale Testing at PNNL. PNNL-12093, Pacific Northwest National Laboratory, Richland, Washington.

Powell, M.R., Y. Onishi, and R. Shekarriz. 1997. Research on Jet Mixing of Settled Sludges in Nuclear Waste Tanks at Hanford and Other DOE Sites: A Historical Perspective. PNNL-11686, Pacific Northwest National Laboratory, Richland, Washington.

Ramsower, D.C. 1996. Sluicing Nozzle Test Report, Volume 1. WHC-SD-WM-TD-013, Rev. 0A, Westinghouse Hanford, Company, Richland, Washington.

Ramsower, D.C. 1996. Test Results for Robotic Manipulator EMMA. WHC-SD-WM-TD-012, Rev. 0, Westinghouse Hanford, Company, Richland, Washington.

Rasumssen, O.R. 1998. Waste Feed Delivery Technical Basis, Volume III, Waste Feed Delivery System Description. HNF-1939, Vol. II, Rev. 0, Lockheed Martin Hanford Corporation, Richland, Washington.

Rinker, M.W., B.K. Hatchell, M.R. Powell, J.H. Lee, G. Healey, P.W. Gibbons. 1999. Retrieval of Uranium Sludge from an Iraqi Tank. American Nuclear Society, Eighth International Topical Meeting Robotics and Remote Systems, April 25-29, 1999, Pittsburgh, Pennsylvania. American Nuclear Society Order No. 700271, La Grange Park, Ilinois.

Rinker, M.W., D.G. Alberts, J.A. Bamberger, B.K. Hatchell, K.I. Johnson, O.D. Mullen, M.R. Powell, D.A. Summers. 1996. Tanks Focus Area Retrieval Process Development and Enhancements FY96 Technology Development Summary Report. PNNL-11349, Pacific Northwest National Laboratory, Richland, Washington.

Rinker, M.W., D.G. Alberts, J.A. Bamberger, E.A. Daymo, C.W. Enderlin, F.F. Erian, B.K. Hatchell, K.I. Johnson, O.D. Mullen, M.R. Powell, D.A. Summers. 1997. EM-50 Tanks Focus Area Retrieval Process Development and Enhancements FY97 Technology Development Summary Report. PNNL11734, Pacific Northwest National Laboratory, Richland, Washington.

Rule, V.A., B.L. Burkes, S.D. Van Hoesen. 1998. The North Tank Farm Data Report for the Gunite and Associated Tanks at Oak Ridge National Laboratory, Oak Ridge, Tennessee. ORNLI/TM-13630, Oak Ridge National Laboratory, Oak Ridge, Tennessee.

Tedeschi, A.R. 2000. Derived Requirements for Double-Shell Tank High-Level Waste Auxiliary Solids Mobilization. RPP-5664, Rev. 0, CH2M Hill Hanford Group, Inc. Richland, Washington.

Whyatt, G.A. and C.R. Hymas. 1997. Bench-Scale feasibility Testing of Pulsed-Air Technology for InTank Mixing of Dry Cementitious Solids with Tank Liquids and Settled Solids. PNNL-11690, Pacific Northwest National Laboratory, Richland, Washington.

WSRC. 1997. Basis for Interim Operation (BIO) for Liquid Radioactive Waste Handling Facilities. WSRC-RP-94-346, Rev. 3, Westinghouse Savannah River Company, Aiken, South Carolina. 
PNNL-13048

\section{Distribution}

No. of

Copies

OFFSITE

1 DOE/Office of Scientific and Technical Information and Information Release

1 S. Barnes

10282 Rock Springs Rd. MSIN: WV-48

West Valley, NY 14171

1 F. Damerow

10282 Rock Springs Rd.

West Valley, NY 14171-9799

2 N. R. Davis

Westinghouse Savannah River Company 703-H Bldg.

Aiken, SC 29801

1 P. L. Davis

Westinghouse Savannah River Company 742-9G Bldg.

Aiken, SC 29801

1 J. R. Noble-Dial

U.S. Department of Energy

Oak Ridge Operations Office

P.O. Box 2001

Oak Ridge, TN 37830-8620

1 J. L. Drake, Jr

West Valley 10282 Rock Springs Rd.

West Valley, NY 14171

\section{J. R. Farmer}

Oak Ridge National Laboratory

Bethel Valley Road, Bldg. 1000 (MS 6341)

Oak Ridge, TN 37831
No. of

Copies

\section{OFFSITE}

1 D. W. Geiser, EM-50

US Department of Energy

Tanks Focus Area

Cloverleaf Building

19901 Germantown Road

Germantown, MD 20874-1290

1 K. Gerdes

Office of Science and Technology

Program Manager - Tanks Focus Area

19901 Germantown Road

1154/Cloverleaf Bldg.

Germantown, MD 20874-1290

1 T.S. Gutmann

U.S. Department of Energy

Savannah River Operations Office

P.O. Box A, Bldg. 704-S

Aiken, SC 29802

1 H. M. Handfinger

Westinghouse Savannah River Company 704-S Bldg.

Aiken, SC 29801

1 M. Jensen

Lockheed Martin Idaho Technologies

Company

P.O. Box 1625, MS 3204

Idaho, Falls, ID 83415-3204

1 M. A. Johnson

Oak Ridge National Laboratory

P.O. Box 2008, MS 6306

Oak Ridge, TN 37831-6306

Distr. 1 


\section{Distribution}

No. of

Copies

\section{OFFSITE}

1 T. J. Lex

Westinghouse Savannah River Co.

Savannah River Technology Center

703-H Building

Aiken, SC 29808

1 B. A. Martin

Westinghouse Savannah River Company 742-9G Bldg.

Aiken, SC 29801

1 T. M. Monahon

Westinghouse Savannah River Co.

Savannah River Technology Center 703-H Building

Aiken, SC 29808

1 J. P. Morin

Westinghouse Savannah River Co.

Savannah River Technology Center

703-H Building

Aiken, SC 29808

1 S. M. Robinson, MS-6044

Martin Marietta Energy Systems, Inc.

Oak Ridge National Laboratory

P.O. Box 2008

Oak Ridge, TN 37831
No. of

Copies

\section{OFFSITE}

1 P. W. Wool, MS-1145

Idaho National Engineering and

Environmental Laboratory

U.S. Department of Energy

750 DOE Place

Idaho Falls, ID 83402

1 A. M. Jensen, MS-3204

Lockheed Martin Idaho Technology Co.

P.O. Box 1625

Idaho Falls, ID 83415-3204

1 T.S. Gutmann

U.S. Department of Energy

Savannah River Operations Office

P.O. Box A

Aiken, SC 29802

1 B. E. Lewis, Jr.

Oak Ridge National Laboratory

P.O. Box 2008, MS6305

Oak Ridge, TN 37831-6305

Distr. 2 
PNNL-13048

\section{Distribution}

No. of

Copies

ONSITE

20 Hanford Site

E. J. Berglin

H3-26
A. B. Carlson

P. J. Certa

A. F. Choho

T. J. Conrads

J. S. Garfield

M. G. Glasper

J. O. Honeyman

C. S. Louie

E. A. Pacquet (5)

C. P. Shaw (2)

A. R. Tedeschi

W. T. Thompson

R. L. Treat

W. L. Willis

R3-73

R3-73

R3-73

R3-73

R3-73

K8-50

H6-18

H6-60

R3-47

S7-70

R1-31

R3-73

H6-19

R3-73

8 Tanks Focus Area Technical Team

B. J. Williams

K9-69
No. of

Copies

ONSITE

2 Retrieval Technology Integration Manager

P. W. Gibbons $\quad$ K9-91

1 Tanks Focus Area Field Lead

T. P. Pietrok K8-50

25 Pacific Northwest National Laboratory

K. M. Airhart (4) K5-22

J. A. Bamberger (6) K7-15

W. F. Bonner K9-14

J. L. Buelt K9-09

B. A. Carteret K9-91

C. W. Enderlin K7-15

F. F. Erian K7-15

B. K. Hatchel K5-22

W. L. Kuhn K7-15

O. D. Mullen K5-22

M. W. Rinker (6) K5-22

G. A. Whyatt K6-24

Distr. 3 